Florida International University FIU Digital Commons

$11-3-2014$

\title{
Life Experiences of Youth Who Were Born with HIV Infection in Puerto Rico: The Voices of Young Survivors
}

Georgina Silva-Suarez

Florida International University, gsilv010@fiu.edu

DOI: $10.25148 /$ etd.FI14110726

Follow this and additional works at: https:// digitalcommons.fiu.edu/etd

Part of the Public Health Education and Promotion Commons, and the Quantitative, Qualitative, Comparative, and Historical Methodologies Commons

\section{Recommended Citation}

Silva-Suarez, Georgina, "Life Experiences of Youth Who Were Born with HIV Infection in Puerto Rico: The Voices of Young Survivors" (2014). FIU Electronic Theses and Dissertations. 1614.

https://digitalcommons.fiu.edu/etd/1614 


\title{
FLORIDA INTERNATIONAL UNIVERSITY
}

Miami, Florida

\section{LIFE EXPERIENCES OF YOUTH WHO WERE BORN WITH HIV INFECTION IN PUERTO RICO: THE VOICES OF YOUNG SURVIVORS}

\author{
A dissertation submitted in partial fulfillment of \\ the requirements for the degree of \\ DOCTOR OF PHILOSOPHY \\ in \\ PUBLIC HEALTH \\ by \\ Georgina Silva-Suárez
}


To: Dean Michele Ciccazzo

R.Stempel College of Public Health and Social Work

This dissertation, written by Georgina Silva-Suárez, and entitled Life Experiences of Youth Who Were Born with HIV in Puerto Rico: The Voices of Young Survivors, having been approved in respect to style and intellectual content, is referred to you for judgment.

We have read this dissertation and recommend that it be approved.

$\begin{array}{r}\hline \text { H. Virginia McCoy } \\ \hline \text { Consuelo Beck-Sagué } \\ \hline \text { Silvia E. Rabionet } \\ \hline \text { Mario De La Rosa } \\ \hline \text { Elena Bastida, Major Professor }\end{array}$

Date of Defense: November 3, 2014

The dissertation of Georgina Silva-Suárez is approved.

Dean Michele Ciccazzo R.Stempel College of Public Health and Social Work

Dean Lakshmi N. Reddi University Graduate School

Florida International University, 2014 
(C) Copyright 2014 by Georgina Silva-Suárez

All rights reserved. 


\section{DEDICATION}

In our complex world, there are some beings who have a great impact on the lives of others but never realize that this was the case. When one such being continues to inspire others despite his death, his impact becomes even greater. This dissertation is dedicated to my cousin José Manuel Suárez Pupo. I want to let him know that, “although I was only 10 years old when you left us, my love and admiration for you has only grown with the passing years. With every milestone that I reach and every challenge that I face in the field of HIV, I feel that you are very close to me. I love you and thank you for giving special meaning to my work.”

I also dedicate this work to my family that has always supported and believed in me. To my mother Jenny Suárez, my aunt Regina Suárez, and Soco I thank you for motivating me to continue onward, and for constantly urging me to take one day at a time. To my sister Regina, thank you for hearing me out and for giving me sound advice. To my aunt Reginita, I value your affection and your support in completing this dissertation. To my husband José, many thanks for your love and unconditional support. Finally, thanks to the Trujillo-Silva family for receiving me, supporting me, loving me, guiding me, and always encouraging me to go forward. Without their help, this dissertation would not have been possible. 


\section{ACKNOWLEDGMENTS}

I would like to acknowledge and thank the members of my dissertation committee. I appreciate the support and guidance that I received from Dr. Elena Bastida. Her expertise on qualitative research was critical to the design of the study. Her constant reminders on the importance of participants' voices are clearly reflected not only in the data analysis, but permeate all components of the present work. In addition to painstakingly reviewing and editing my writing, she made sure that I remained true to the proposed methodology and provided valuable mentoring throughout all phases of the dissertation. Dr. Consuelo Beck-Sagué shared her expertise on pediatric HIVAIDS and believed in my work from the very beginning. She also carefully read and reviewed several drafts of the dissertation and remained vigilant of procedures. Dr. Mario de la Rosa was always supportive and willing to work with me and my major professor. He also made valuable suggestions on the role of the Puerto Rican family and as it related to my study population. Dr. H. Virginia McCoy gave me the opportunity to join this program and has been a guiding light during my doctoral studies. Dr. Silvia E. Rabionet not only believed in me, but was also a mentor, cheerleader, facilitator, guide, and friend.

I must also thank and acknowledge the Graduate School at Florida International University for awarding me a Dissertation Year Fellowship. I also am grateful for the support of the National Institute of Mental Health for supporting this study through the Puerto Rico Mentoring Institute for HIV and Mental Health Research (grant \#1R25MH083617).

Many thanks to Dr. Carmen Zorrilla and the staff of CEMI for supporting me during the course of my doctoral studies and research. Dr. Irma Febo, Catherine Cruz 
and the staff of the University of Puerto Rico Pediatric HIV/AIDS Research Program deserve my gratitude for agreeing to collaborate in this research from day one, facilitating the entire process.

The collaboration of Ana C. Arboleda, research assistant, was key to this project. Dr. Annette B. Ramírez de Arellano was more than editor; she guided me and was a source of inspiration and motivation during the process. Dr. Ana-María Nuevo, believed in the importance of my work and her edits were essential for the final product of my dissertation.

Lastly, and most important, I acknowledge and thank the study participants: the brave young men and women who trusted me, believed in the importance of this project, and shared their most intimate and personal life experiences with me. To them, a heartfelt “ $i$ Gracias!” because, without their willingness to share their life stories, this research would not have been possible. 


\title{
ABSTRACT OF THE DISSERTATION \\ LIFE EXPERIENCES OF YOUTH WHO WERE BORN WITH HIV INFECTION IN PUERTO RICO: THE VOICES OF YOUNG SURVIVORS
}

\author{
by \\ Georgina Silva-Suárez \\ Florida International University, 2014 \\ Miami, Florida \\ Professor Elena Bastida, Major Professor
}

The effectiveness of antiretroviral therapy (ART) transformed the pediatric HIV epidemic. The disease changed significantly over the course of three decades: while early in the epidemic it was almost always fatal, it has become a chronic condition.

This study examined how perinatally-infected youth experience the impact of HIV in their lives. A qualitative study using interpretative phenomenological analysis (IPA) was conducted. Twenty in-depth interviews were carried out among 12 women and 8 men aged 18 to 30 years in Puerto Rico. These were conducted in Spanish, audiorecorded, transcribed and translated into English. While narrating their experiences, participants were interpreting what the situation meant to them and how they make sense of it.

Three topics emerged: (1) perception and response to treatment and illness, particularly their lived experiences with ART; (2) disclosure experiences; and (3) family matters. Most participants challenged their therapy, in most cases to force their caregivers to disclose their status. Problems with adherence were attributed to busy schedules or forgetfulness. Participants experienced the disfiguring adverse effects of 
ART, which they endured for years without being informed that ART was the cause of these. Participants' experiences with disclosure demonstrated the importance of validating them as individuals capable of managing their health. The paternalistic approach of withholding their diagnosis to spare them suffering resulted in increased anxiety. Participants acknowledged the difficulties of revealing their HIV status to their partners. They referred to family and friends as essential in coping with HIV. However, some encountered discrimination and stigma within their families. Participants who had suffered the loss of their parents found other parental figures such as adoptive parents or other family members. Most participants expressed a desire to have children.

Perinatally HIV-infected youth will require health services for the rest of their lives. The adult health care into which they transition should consider their needs and journey. Services should consider including family members. This study underscores the need for improved access to mental health services. It is also essential to transcend medical treatment and develop a broader perspective of health care. Health care services should include reproductive decision-making counselling services. 


\section{TABLE OF CONTENTS}

CHAPTER

PAGE

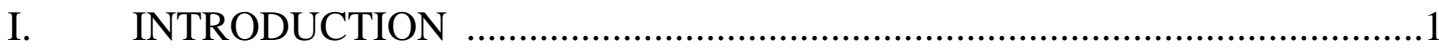

Background and Significance .....................................................................

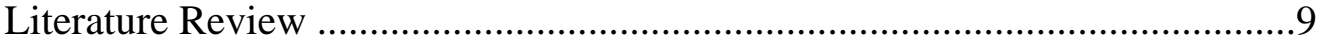

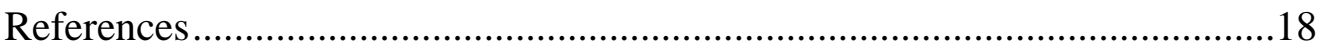

II. STUDY DESIGN AND METHODOLOGY ………....................................23

Methodological Framework …………………………................................23

Philosophical Currents ..............................................................................23

Graphic Representation of the Theoretical Framework ...................................26

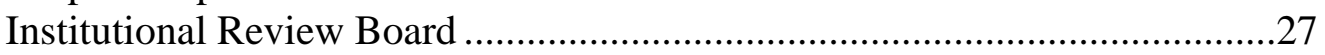

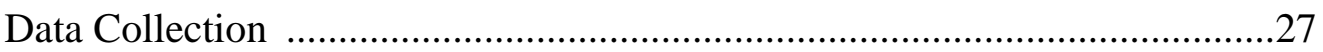

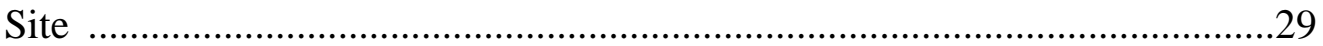

Sample Selection .....................................................................................

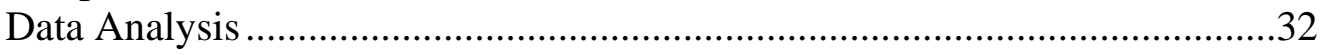

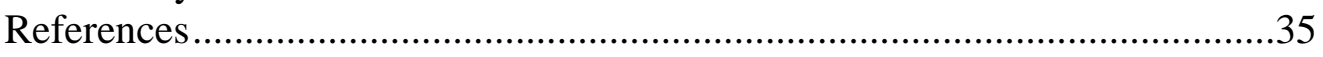

III. FIRST MANUSCRIPT ………………………..................................36

A Tough Pill to Swallow: The Meaning of ART for Puerto Rican

Perinatally-Infected Youth ..............................................................................36

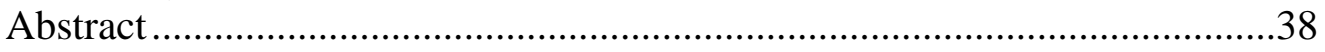

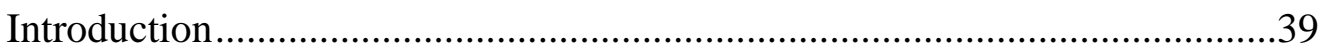

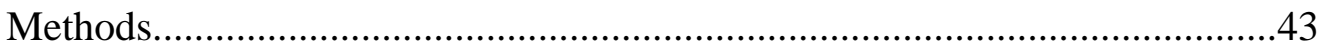

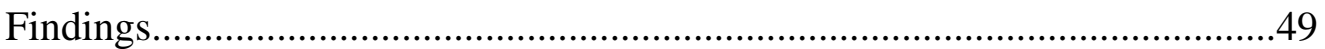

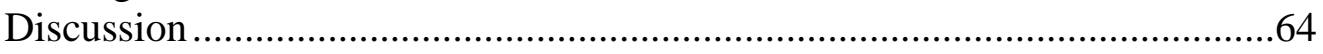

Conclusion and Implications...........................................................................

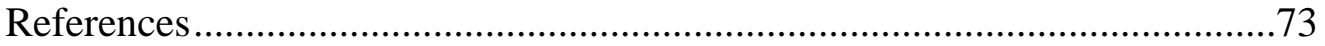

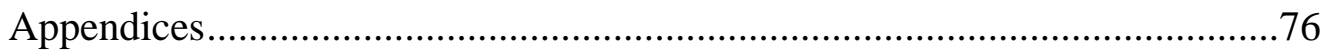

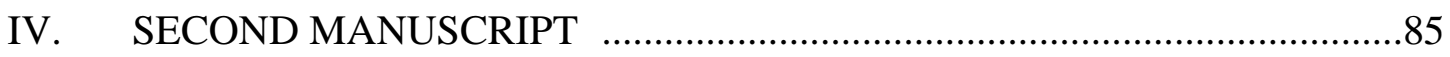

Reconstructing the Truth: The Life Experiences of Puerto Rican

Perinatally-Infected Youth with Disclosure.......................................................85

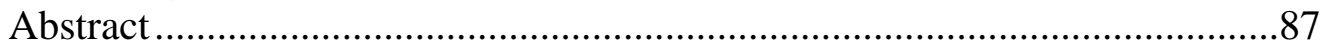

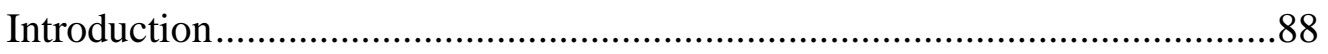

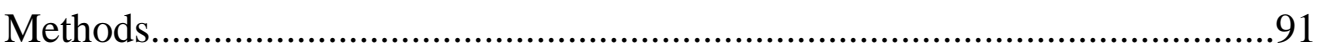

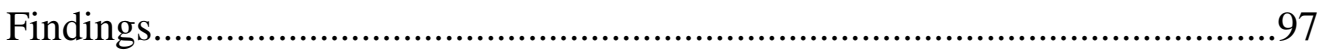

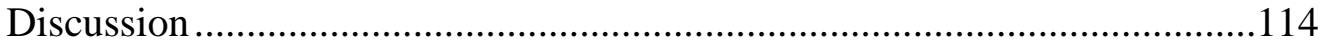

Conclusion and Implications.......................................................................118

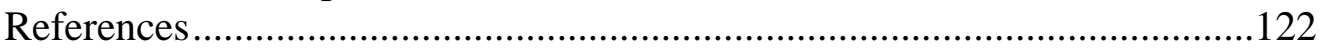

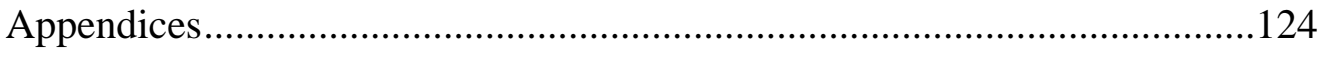


V. THIRD MANUSCRIPT ………………………...................................134

That's True Love: Lived Experiences of Puerto Rican Perinatally

HIV-Infected Youth within Their Families Context.......................................134

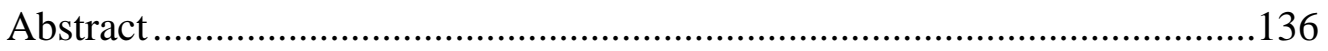

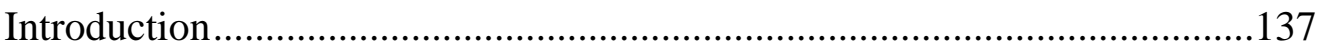

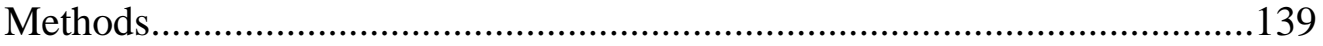

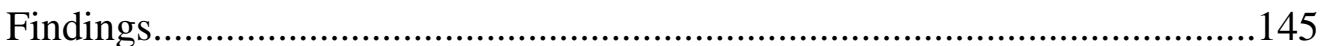

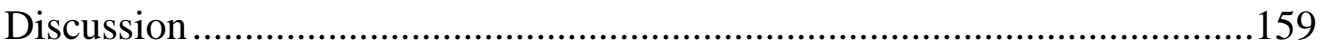

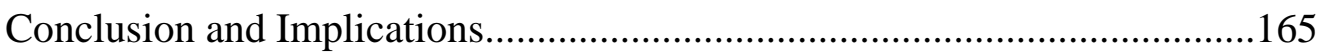

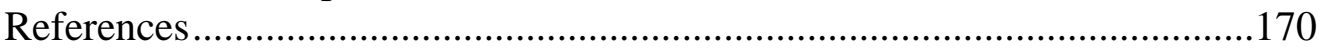

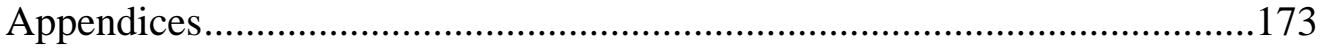

VI. CONCLUDING REMARKS AND RECOMMENDATIONS TO INFORM

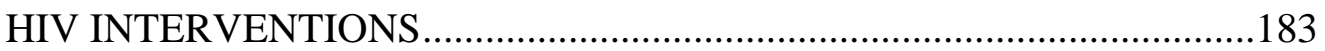

VII. STUDY LIMITATIONS ………………………..................................190

VIII. FUTURE PATHS ………………………………..................................191

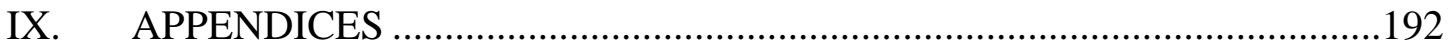

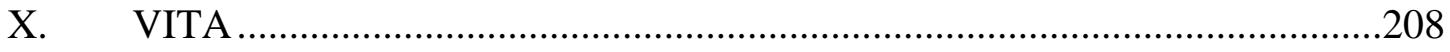




\section{ACRONYMS AND ABBREVIATIONS}

AIDS

CDC

CEMI

HIV

IDU

IPA

MSM

PACTG

pHIV-I

UNAIDS

WHO
Acquired Immunodeficiency Syndrome

Centers for Disease Control and Prevention

Centro de Estudios Materno Infantil (Maternal Infant Study Center)

Human Immunodeficiency Virus

Injecting Drug Use

Interpretative Phenomenological Analysis

Men having Sex with Men

Pediatric AIDS Clinical Trial Group

Perinatally HIV Infected

Joint United Nations Programme on HIV and AIDS

World Health Organization 


\section{INTRODUCTION}

\section{Background and Significance}

Success in prolonging the lives of children living with HIV infection through the use of antiretroviral therapy (ART) has transformed pediatric HIV, and resulting in new challenges as these children have entered adolescence and adulthood worldwide (Gortmaker et al., 2001; Sutcliffe, Van Dijk, Bolton, Persaud, \& Moss, 2008). The disease has changed significantly over the course of more than three decades: while early in the epidemic it was often fatal, it has largely become a chronic condition requiring long term treatment and support (Fernet et al., 2007; Hazra, Siberry, \& Mofenson, 2010; Zorrilla, Rabionet, Mosquera, \& Ramírez de Arellano, 2012). Perinatally-infected HIV patients have defied the odds; while they "were not expected to live beyond early childhood, now they are living healthy and longer” (Hogwood, Campbell \& Butler, 2012, p. 2).

As they live longer, healthier lives, perinatally HIV-infected youth also face a variety of issues including: stigma and discrimination; delayed disclosure of their diagnosis; challenges related to medication adherence; losses and resultant bereavement; poverty; and abnormal stigmatizing physical appearance and body changes, among others (Koenig, Nesheim \& Abramowitz, 2011). Perinatally-infected youth are affected by others' lack of knowledge of HIV, and may fear rejection and discrimination when they disclose their HIV status (Blasini et al., 2004; Hogwood et al., 2012). They often mention the dilemma they face concerning whether or not to disclose their condition. Some are reluctant to disclose it primarily due to fear of rejection and the stigma associated with the disease (Brown \& Lourie, 2000; Hogwood et al., 2012). Beyond the 
issues of patients' self-image and how they are seen by others, disclosure also has implications for adherence to medication. Perinatally-infected adolescents may conceal their medications, lie to their friends about their medications, or fail to take them as these medications label them as HIV-infected (Michaud et al., 2010). Lack of adherence to ART, which is often related to mental health and behavioral issues, in turn promotes progression of the disease, adversely affects quality of life, and even the survival of youth living with HIV (Mellins, 2002).

Perinatally-infected patients are likely to have suffered the loss of one of more of their parents or family members due to AIDS (Blasini et al., 2004; Brown \& Lourie, 2000; Harvey \& Wenzel, 2002). Because of the stigma associated with HIV, these youths may not receive the support they need to address bereavement and cope with their losses. Indeed, they may consider the death of their parent as something shameful (Brown \& Lourie, 2000). Family members become the immediate source of support for this population. For Puerto Rican, the cultural group of the present study, social relationships are important and the support given by family and friend are highly valued (Varas-Díaz, Serrano-García, \& Toro-Alfonso, 2005). When HIV stigma and discrimination take place within the family context it threatens the well-being of people living with HIV. Stigma and incrimination can reduce the immediate support which is traditionally offered by family members (Varas-Díaz et al., 2005). These challenges are interrelated and must be considered when addressing the needs of this population as youth approach adult care.

In addition to dealing with the medical implications of the disease, people living with HIV confront an array of social and structural constraints that often interfere with 
their treatment (Franco et al., 2009). Perinatal HIV infection disproportionately affects the poorest and most underserved populations worldwide, where access to support is the most limited (Hazra et al., 2010). Despite many advances in treatment, perinatallyexposed and infected infants share elements of vulnerability, poverty, and low socioeconomic status (Franco et al., 2009). There is strong evidence suggesting that "[HIV-] affected households are economically worse off than unaffected households and also express concerns about meeting basic needs” (Franco et al., 2009, p. 52).

At the end of 2009, in the United States there were an estimated 10,834 persons who had been diagnosed with HIV, at an age younger than 13 years old; 88\% $(9,522)$ of these were perinatally-infected (CDC, 2012). In Puerto Rico, 144 and 419 children under the age of 13 years were diagnosed with HIV infection and AIDS, respectively, between 1985 and January-2014. On the island, perinatal transmission accounts for 94\% of AIDS pediatric cases and 73\% of HIV pediatric cases (Puerto Rico Department of Health, 2014).

Since the beginning, the epidemic in Puerto Rico shares common characteristics with that of many other countries worldwide. By 1998, Puerto Rico was among the United States and its territories with the highest incidence of AIDS (CDC, 1998). The major routes of transmission were injecting drug use (IDU) (52\%), heterosexual contact (22\%), and men having sex with men (MSM) (17\%) (Gómez, Fernández, Otero, Miranda, \& Hunter, 2000). Exposure categories tended to vary by gender. Men acquired HIV infection mainly as a result of IDU and by having sex with men, while women were primarily infected through heterosexual contact, followed by IDU (Gómez et al., 2000). Women comprised the fastest growing population with AIDS in the last years of the $20^{\text {th }}$ 
century, accounting for 22.3\% of all reported adult cases (Pérez-Perdomo, PérezCardona, \& Suárez-Pérez, 1999). Between 1985 and 1997, AIDS cases among women rose from 14 (14.4\%) to 525 (25.8\%) (Pérez-Perdomo et al., 1999). This increase in AIDS cases among women directly impacted pediatric cases. In 1983, the first two pediatric AIDS cases were diagnosed in Puerto Rico, and in 1985 the first pediatric case was reported to the US AIDS Surveillance System.

It should be highlighted that in Puerto Rico by January 2014 there were 36,293 and 9,496 AIDS and HIV cases reported, respectively. The three principal modes of transmission of HIV were heterosexual contact $(36 \%$ [3,394]), injection drug use (32\% [2,991]), and sex among MSM (21\% [2,009]). Thirty seven percent $(2,999)$ of HIV infection cases are among women and $68.4 \%(6,497)$ among men. The primary route for HIV transmission for women was heterosexual contact $(72 \%$ [2,108]), followed by IDU (21\% [614]). For men, the primary mode of HIV transmission was IDU, accounting for $37 \%(2,377)$ of cases, followed closely by sexual contact among MSM $(31 \%[2,009])$. Among men, heterosexual contact accounted for $20 \%(1,286)$ of HIV infections (Puerto Rico Department of Health, 2014).

The Medical Sciences Campus of the University of Puerto Rico (UPR), in addition to being the principal academic medical institution on the island, is a major research center housing a variety of programs offering services to the HIV-positive population. One of these is the University of Puerto Rico (UPR) Pediatric HIV/AIDS Research Program created in 1986. One of the major goals of the UPR Pediatric HIV/AIDS Research Program is to promote research, education, treatment and comprehensive services to children and adolescents living with HIV/AIDS in order to 
enhance their quality of life and improve survival. Services at the UPR Pediatric HIV/AIDS Research Program are provided by a multidisciplinary team which has been with the center since its founding. Because the staff turnover at the UPR Pediatric HIV/AIDS Research Program has been minimal over the last 20 years, there has been continuous care and a high degree of bonding not only among the healthcare providers, but also between them and their HIV-infected patients and patients' family members. Project staff has therefore witnessed their patients grow and develop from infants to toddlers to adolescents and beyond.

Created as a research unit at the beginning of the epidemic, the UPR Pediatric HIV/AIDS Research Program has promoted a research culture among patients and families. The unit has been at the forefront of pediatric research, enrolling participants in research protocols and hence offering them access to new treatments. As a result, most UPR Pediatric HIV/AIDS Research Program patients are research "savvy" and recognize the importance of participating in HIV protocols and studies. Because many adolescents and young adults were clinic patients when there were no effective treatments for HIV infection during the early days of the epidemic, research was an essential part of patient care. Moreover, it was through research "that people living with HIV would have access to a potentially lifesaving drug or therapy” (Zorrilla et al., 2007, p.331). Access to treatment through research participation has therefore been a key component of the UPR Pediatric HIV/AIDS Research Program.

The UPR Pediatric HIV/AIDS Research Program has led or collaborated in many successful research projects to date. One of the most important, and the one that catapulted the researchers at the UPR School of Medicine as "pioneers in the 
management of pregnant women and children living with HIV," was their participation in the Pediatric AIDS Clinical Trial Group (PACTG) 076 study (Connor et al., 1994: Zorrilla et al., 2007, p.331). This research protocol provided zidovudine to women during pregnancy and labor as well as to the infant for six weeks starting hours after birth. In 1994, the PACTG Data and Safety Monitoring Board reviewed the interim analysis based on database information as of December 20, 1993. The Board concluded that there was sufficient evidence of treatment efficacy for preventing mother-to-child transmission and recommended the discontinuation of new patient enrollment. They offered open-label zidovudine to all individuals in the study and long-term follow-up of participating infants to monitor for possible development of late effects of perinatal zidovudine use (National Institute of Allergy and Infectious Diseases [NIAID], 1994; Zorrilla et al., 2007).

Throughout its history, the UPR Pediatric HIV/AIDS Research Program has cared for over 1,000 children and adolescents living with or perinatally exposed to HIV. Currently, they follow 45 children and adolescents living with HIV; of these, 90\% acquired HIV perinatally.

In Puerto Rico, research on vertical HIV transmission has focused on the effects of disclosure of their HIV diagnosis to children using the UPR Pediatric HIV/AIDS Research Program's own disclosure model, examined trends in HIV perinatal infection, adherence to ART and pregnancy in HIV perinatally-infected youth (Blasini et al., 2004; CDC, 2003; Gomez et al., 2000; Rodríguez, 2009; Zorrilla et al., 2007). There is a need to examine the life experiences of these perinatally-infected youth living with HIV in Puerto Rico, a unique population that has overcome the expectations of early death 
associated with HIV infection in the 1990s and who are living longer and productive lives into young adulthood. This research study is the first study to explore the life experiences of perinatally-infected young adults living with HIV in Puerto Rico. Because the study population is part of the UPR Pediatric HIV/AIDS Research Program, considerable longitudinal clinical, laboratory, psychometric, psychological and behavioral data have been analyzed in previous studies (Blasini et al., 2004; Zorrilla et al., 2007). The current effort will complement the previous research by describing another aspect of their lives, documenting the life experiences of the first generation of perinatally HIV-infected youth to survive childhood and adolescence in Puerto Rico.

This research study uses a qualitative approach to explore the nature of living with HIV and the meaning that participants give to their experiences. The study's main objective is to examine how perinatally-infected youth experience and describe the impact of HIV in their lives. Specifically, the study will focus on their personal, medical care, and social experiences, emphasizing their perception of and response to treatment and illness, disclosure experiences, family matters and evolution to adulthood. Understanding these experiences is the central thrust of this research.

Capturing the voices and everyday experiences of adolescents living with HIV in Puerto Rico will provide insight into their journey and the psychosocial aspects of being a perinatally-infected youth living with HIV; increase understanding of their trajectory; and inform the design of processes to respond to their unique needs. Moreover, participants may also benefit, feeling that they are helping others while sharing their stories. Atkinson (2002) has pointed out some of the benefits of sharing life stories, including a stronger self-image, and attaining a sense of satisfaction, joy, and inner peace. Voicing 
their experiences may also contribute to feelings of empowered (Atkinson, 2002;

Dickson-Swift, James, \& Liamputtong, 2008; Leonard \& Ellen, 2008). Through their life experience, we will be able to look beyond the medical and physical aspects of the condition to focus on their daily struggles, triumphs, and challenges.

Furthermore, presenting their experiences will "perform the more public function of activating communities of listeners and promoting advocacy and awareness about their needs” (Leonard \& Ellen, 2008). Currently, the possibility of eliminating perinatal transmission of HIV has spurred welcome interest in this area (Joint United Nations Programme on HIV/AIDS [UNAIDS] 2011]). But this has also tended to reduce the visibility of perinatally-infected persons of all ages and the understanding that they have needs different from those of behaviorally-infected counterparts. The current effort should therefore boost advocacy for this population (Fair \& Albright, 2012).

As previously noted, the emergence of a generation of perinatally-infected adolescents into adulthood was unprecedented. Just 15 years ago, survival into adulthood was a rare exception in perinatally-acquired infection (Hogwood et al., 2012). In Puerto Rico, an island with a complex sociocultural landscape, which has borne a heavy burden of HIV, the triumph of coming of age with HIV also posed considerable challenges. Currently, these remain understudied and therefore largely neglected. The findings of this study will help to create and improve services for perinatally-infected youth and adults and inform the process of transitioning this population into adult comprehensive care.

Perinatally HIV-infected youths are a population that has experienced and overcome many life challenges. Overcoming challenges has become a way of life for 
these youths. Most have experienced the loss of their parents and friends due to HIVinfection and faced stigma and discrimination. They have also dealt with issues of disclosure, fear of rejection, as well as medication intake and adherence. These challenges are all part of living a life with a positive attitude and without stigma or fear. Studying their life experiences is vital to understanding the lives of these survivors who have been fighting for their lives since birth. As recommended by Persson and Newman (2012), research studies among this population must consider their social context or lived experiences. Informants must be seen as "participants" in a study rather than as subjects of study. Collectively, we must expunge the label of 'public health hazard' and see this population as a group from which the scientific and medical community can learn, thereby improving public health practices addressing their needs.

\section{Literature Review}

Perception and Response to Treatment and Illness. Perinatally HIV-infected patients have overcome considerable odds. Because of the effectiveness of ART, HIV infection in perinatally-infected patients has now become a chronic illness to a great degree (Lee \& Johann-Liang, 1999). Hazra et al. (2010, p.169) states that, "pediatric HIV care focuses on morbidity related to long-term HIV infection and its treatment.”

Research studies have found that "pediatric HIV patients experience more subjective distress than their uninfected peers” in addition to experiencing physical pain, and anxiety; these patients tend to be less socially active and less successful academically (Brown \& Lourie, 2000, p.85). Having the support of friends has proven essential to coping with their health situation (Sherman, Bonanno, Wiener, \& Battles, 2000). One of the many ways in which perinatally-infected youth differ from their peers is that they 
need to take medication in order to preserve their health. Unlike the case for youth with other chronic illnesses, such as diabetes or cancer, their treatment, while highly effective, is also highly stigmatizing, singling them out as having a disease inextricable connected with homosexuality, IDU, commercial sex work, and other "undesirable” behaviors. As perinatally-infected children become adolescents and young adults, they become indistinguishable from "behaviorally"-infected persons, losing the status of "innocent victims” that they had during their childhood. As such, perinatally HIV-infected adolescents may hide their ART use, lie to their friends about it, or fail to take it altogether (Michaud et al., 2010).

While the patients are children, their parents or caregivers are responsible for their treatment (Hazra et al., 2010). As the children grow and enter adolescence, they assume increasing responsibility for taking medication. Many researchers have observed that adherence to ART often deteriorates for a variety of reasons, including forgetting, stigma, problems with body image, and a desire to be 'normal' (Hazra et al., 2010; Michaud et al., 2010). For perinatally HIV-infected youth, taking medications is difficult because they are often asymptomatic and may not necessarily understand the importance of strictly following their regimen. In addition, some feel that taking medications is a negative reminder of their health situation (Vijayan, Benin, Wagner, Romano, \& Andiman, 2009). The adverse effects of their medication are often more visible to them than the risks of non-adherence. Yet poor or non-adherence to their medication regimen places them at risk for many dangerous consequences, including disease progression and death, the selection of viral antiretroviral-resistance mutations, resistance to antiretroviral 
medication, and the spread of drug-resistant strains of the virus (Hazra et al., 2010; Mitchell \& Linsk, 2004).

The life course of an individual is full of life transitions and trajectories (Elder, 1998). Perinatally-infected youth undergo many critical and emotionally intense transitions in their lives. In addition to the usual developmental stages through which all youths pass, those who are infected must assume responsibility for adhering to their medication during their adolescence. One of the most critical of these transitions occurs during the transfer from pediatric care to adult care, a transition that was never anticipated at the onset of the epidemic. Because the transition is relatively new, transition models from other chronic diseases are being examined, although they may not be entirely applicable (Dowshen \& D'Angelo, 2011).

Transition to adult care is not only difficult for the patients but also for the physician who has been taking care of the perinatally-infected youth patients since their birth. Pediatric providers may be reluctant to let go of their patients, and often resist the idea of transferring their patients to adult care (Wiener, Kohrt, Battles, \& Pao, 2011). Providers fear that adult care may be less welcoming and will not provide the pressurefree environment the patients are used to (Vijayan et al., 2009). There may also be concerns about the quality of medical care that they may receive in settings where experience with perinatally-acquired infection is relatively limited (Koenig et al., 2011). Often, pediatric providers may feel that their sheltered, fragile youth, with their complex medical needs, may face impatience as well as crowded and less personal care in adult clinical settings, where their behaviorally-infected counterparts often require less complicated care. 
The majority of these young patients have received interdisciplinary and coordinated health services; one concern is therefore the fragmentation of most adult care (Dowshen \& D'Angelo, 2011). A research study found that pediatricians were perceived as more available to answer questions, clear up doubts, and offer support to their patients and families (Reiss, Gibson, \& Walker, 2005). Most perinatally infected youth have been receiving medical care since they were born; frequently, they have been cared for by the same healthcare provider. The transition to adult care therefore represents a distressing situation comparable to the loss of a valued family member (Dowshen \& D'Angelo, 2011; Valenzuela et al., 2011). Patients' concerns regarding the transition to adult care include: privacy issues, lack of personalized care, and loss of effective communication with their health care provider (Valenzuela et al., 2011; Vijayan et al., 2009; Wiener et al., 2011).

Disclosure. The lives of perinatally-infected children often have been cloaked in silence and secrecy (Sherman et al., 2000; Vijayan et al., 2009). Unlike children with other chronic diseases, perinatally-infected children are less likely to be told about their illness (Hardy et al., 1994 as cited in Lesch et al., 2007). Worldwide, only a minority of perinatally HIV-infected children know their status; although disclosure is more common in industrialized than in low- and middle-income countries, even in the former, only 30\%-40\% know (Pinzón-Iregui, Beck-Sagué \& Malow, 2013). In the UPR Pediatric HIV/AIDS Research Program, prior to the introduction of the disclosure initiative, 80\% of children had received partial, deceptive or no information about their diagnosis (Blasini et al 2004). Revealing their diagnosis to them may require disclosing family secrets (such as adoption, abandonment or biological parental abandonment or 
incarceration) as well as revealing the HIV diagnoses of other family members.

Disclosure therefore has many dimensions related to disclosing to the perinatally-infected youth, as well as to others.

The American Academy of Pediatrics (1999) has recommended disclosing their HIV positive status to children as soon as it is developmentally appropriate. There are two types of disclosure: partial and full disclosure. In partial disclosure, the child knows something about the disease but is unaware of its name, lacks specific information about it, or does not know how he/she acquired it. Full disclosure involves revealing details of the disease to the child, including the name of the disease and specific information about it and how he/she acquired it, and if the route of infection is known (Wiener, Mellins, Marhefka, \& Battles, 2007).

The second important aspect of disclosure is disclosing to others. When, why, and to whom to disclose, are among the questions adolescents living with HIV ask themselves. Public health professionals work diligently to encourage judicious disclosure to prevent risky sexual behavior, as well as transmission of the virus and drug resistance (Wiener et al., 2007). Perinatally-infected youth who may be willing to disclose their HIV status may nevertheless face a number of difficulties, including the uncertainty of others' reactions, fear of rejection, stigma, and fear of losing control of their personal information (Hogwood et al., 2012). These youths are more likely to reveal their diagnosis in specific circumstances such as a being in a romantic relationship, getting married, having a child, and getting a job (Hogwood et al., 2012).

Perinatally-infected youth face additional issues related to disclosing their diagnosis. The families of some of these patients may encourage them to conceal or lie, 
or may forbid their talking about their diagnosis because of fear of rejection and discrimination against them and/or their families (Sherman et al., 2000; Vijayan et al., 2009). The youths may therefore face conflicting advice: while healthcare providers and public health officials encourage them to reveal their diagnosis to their intimate partners, their families may encourage them to conceal their illness as much and as long possible, sometimes all their lives.

Perinatally HIV-infected youth learn very early in their lives about the transmissibility of HIV and that using condoms is the most common prevention strategy to prevent HIV transmission (Fernet et al., 2007). Those who are sexually active often use condoms most of the time, even though they may not necessarily reveal their diagnosis to their partners (Fernet et al., 2007; Sanders, 2008). They may give a variety of reasons for using condoms, prevention of pregnancy being the most frequent rationale (Fernet et al., 2007). Because of the complexity of their situation, their sense of responsibility to others, and their fear of rejection, some may even choose to abstain from certain sexual activities or delay sexual intercourse to avoid full disclosure (Fernet et al., 2007).

Family Matters. Puerto Ricans, as other Hispanic communities, share common values that impact family relationships. The two most prominent are machismo and feminism, which may govern the interpersonal relationship between men and women in society. Machismo refers to the social expectations for men stressing virility, physical strength and sexual prowess (Noland, 2006; Ortíz-Torres, Serrano-García, \& TorresBurgos, 2000). Historically, machismo has been associated with promiscuity, control and domination of female partners (Noland, 2006). 
In a research study conducted in Puerto Rico by Noland (2006) she found that sexual behavior and communication among Puerto Ricans are highly influenced by machismo. There is a social expectation for the men to be sexually experienced and dominant. These behaviors have been reinforced since early childhood often by asking the boys 'how many girlfriends do you have?' However, for women the social expectation is entirely different. They are expected to be virginal, fragile, and submissive. Being sexually experienced is not endorsed among Hispanic female adolescents and young women; nevertheless women are expected to assume responsibility for contraception and condom use (Noland, 2006). These social expectations promote unequal power gender relationships (Ortíz-Torres el al., 2000). In addition to machismo and feminism Hispanic communities seems to share others core values such as familismo, collectivism and simpatía. Familismo is the tight relationship with family and viewing the family as a source of emotional and material support, and the need to protect family members of all ages from adverse consequences, including disturbing information. Collectivism refers to the importance that Hispanics traditionally assign to friends and members of the extended family; simpatía is the importance of smooth and positive interpersonal relationship (Marín, 1989).

Research conducted on HIV "has shown that Puerto Ricans assigned great importance to family relations” (Díaz, 1998 in Varas-Díaz et al., 2005, p.181). For Latinos, close and supportive family relationships are important throughout the lifespan (Díaz, 1998). Puerto Ricans value their social relationships and consider family and friends as major sources of support in their life trajectories (Varas-Díaz et al., 2005). 
The burden of HIV not only affects patients but also their families and caregivers (Gómez et al., 2000). Families of HIV patients have to deal with the stigma and social discrimination that surround the disease (Ji, Li, Lin \& Sun, 2007). In some cases, the disease label may be applied to an entire family. In a village in Nigeria, for example, when one person becomes HIV positive the villagers call the whole family an "AIDS family” (Alubo et al, 2002 as cited in Li et al., 2006). Children of families affected by HIV may struggle to understand why people mistreat them (Ji et al, 2010).

HIV positive individuals and their families also face economic issues. In China, there are reported cases of an employer firing an employee because he/she tested HIV positive (Cao et al, 2005, as cited in Li et al., 2006). Similarly, in the Caribbean, some employers do HIV testing of prospective and current employees, often without consent or informing them of their results with the intention of denying HIV-infected persons employment (Human Rights Watch, 2004). The disease also has financial implication for family members who are expected to provide support to those affected. HIV positive individuals in China have reported that the primary source of support comes from their families. The family not only helps the affected individual to cope with the disease but also provides financial and medical assistance as well as psychological support (Li et al., 2006).

Family support is crucial for people living with HIV and can be crucial to the decision-making process regarding treatment-seeking and other situations (Li et al., 2006). Regarding adolescents living with HIV, family members and caregivers are often the ones who remind them to take their medication (Michaud et al., 2010). For 
perinatally HIV-infected youth, family members assume responsibility for their treatment when they are young children (Hazra et al., 2010).

Support for family members of people living with HIV has to be considered when providing health services. Family members often are the ones responsible for the medical care, social support, and medication adherence of the HIV patient (Ji et al., 2010; Li et al., 2006). When an HIV patient dies, the family assumes responsibility for raising the children of the deceased (Blasini et al., 2004; Brown \& Lourie, 2000). This situation is not only difficult for the children but also for the family that must now face the burden and stress of giving care (Li et al., 2006). 


\section{References}

American Academy of Pediatrics Committee on Pediatrics AIDS. (1999). Disclosure of illness status to children and adolescents with HIV infection. Pediatrics, 103(1), 164-166.

Atkinson, R. (2002). The life story interview. In J.F. Gubrium, \& J. Holstein (Eds.), Handbook of interview research: Context and methods (pp. 121-140). Thousand Oaks, California: SAGE Publications, Inc.

Blasini, I., Chantry, C., Cruz, C., Ortíz, L., Salabarría, I., Scalley, N., \& ... Díaz, C. (2004). Disclosure model for pediatric patients living with HIV in Puerto Rico: Design, implementation, and evaluation. Journal of Developmental \& Behavioral Pediatrics, 25(3), 181-189.

Brown, L. K., \& Lourie, K. J. (2000). Children and adolescents living with HIV and AIDS: A review Journal of Child Psychology and Psychiatry, 41(1), 81-96. doi:10.1111/1469-7610.00550

Centers for Disease Control and Prevention (CDC). (2003). MMWR Weekly: Pregnancy in Perinatally HIV-Infected Adolescents and Young Adults. Center for Disease Control and Prevention. Retrieved from: http://www.cdc.gov/mmwr/preview/mmwrhtml/mm5208a1.htm.

Centers for Disease Control and Prevention (CDC). (1998). HIV/AIDS surveillance report. Center for Disease Control and Prevention, 10(1)

Centers for Disease Control and Prevention (CDC). (2012, December). HIV Among Pregnant Women, Infants, and Children. Retrieved from http://www.cdc.gov/hiv/risk/gender/pregnantwomen/facts/

Connor, E. M., Sperling, R. S., Gelber, R., Kiselev, P., Scott, G., O'Sullivan, M. J., ... \& Balsley, J. (1994). Reduction of maternal-infant transmission of human immunodeficiency virus type 1 with zidovudine treatment. New England Journal of Medicine, 331(18), 1173-1180.

Dickson-Swift, V., James, E. L., \& Liamputtong, P. (2008). Undertaking sensitive research in the health and social sciences: Managing boundaries, emotions and risks. Cambridge: Cambridge University Press.

Dowshen, N., \& D'Angelo, L. (2011). Health care transition for youth living with HIV/AIDS Pediatrics, 128(4), 762-771.

Elder, G. H. (1998, Feb). The life course as developmental theory. Child Development, 69(1), 1-12. Retrieved April 2014, from http://www.jstor.org/stable/1132065 
Fair, C., \& Albright, J. (2012). "Don't tell him you have HIV unless he's 'The one’”: Romantic relationships among adolescents and young adults with perinatal HIV infection. AIDS Patient Care and STDs, 26(12), 746; 746-754; 754.

Fernet, M., Proulx-Boucher, K., Richard, M., Levy, J. J., Otis, J., Samson, J., \& ... Trottier, G. (2007). Issues of sexuality and prevention among adolescents living with HIV/AIDS since birth. The Canadian Journal of Human Sexuality, 16(3/4), 101.

Franco, L. M., Burkhalter, B., de Wagt, A., Jennings, L., Kelley, A. G., \& Hammink, M. E. (2009). Evidence base for children affected by HIV and AIDS in low prevalence and concentrated epidemic countries: Applicability to programming guidance from high prevalence countries. AIDS Care, 21(S1), 49-59.

Gómez, M. A., Fernández, D. M., Otero, J. F., Miranda, S., \& Hunter, R. (2000). The shape of the HIV/AIDS epidemic in Puerto Rico. Pan Am J Public Health, 7(6), 377-383.

Gortmaker, S. L., Hughes, M., Cervia, J., Brady, M., Johnson, G. M., Seage III, G. R., ... \& Oleske, J. M. (2001). Effect of combination therapy including protease inhibitors on mortality among children and adolescents infected with HIV-1. New England Journal of Medicine, 345(21), 1522-1528.

Harvey, J. H., \& Wenzel, A. (2002). HIV, AIDS, and close relationships. Journal of Social and Personal Relationships, 19(1), 135-142. doi:10.1177/0265407502191007

Hazra, R., Siberry, G. K., \& Mofenson, L. M. (2010). Growing up with HIV: Children, adolescents, and young adults with perinatally acquired HIV infection. Annual Review of Medicine, 61, 168-185. doi:10.1146/annurev.med.050108.151127

Hogwood, J., Campbell, T., \& Butler, S. (2012). I wish I could tell you but I can't: Adolescents with perinatally acquired HIV and their dilemmas around selfdisclosure. Clinical Child Psychology and Psychiatry, 0(0), 1-17. doi:10.1177/1359104511433195

Human Rights Watch (HRW). (2004). A Test of Inequality: Discrimination against Women Living with HIV in the Dominican Republic http://www.hrw.org/reports/2004/07/12/test-inequality. Accessed January 28, 2014.

Ji, G., Li, L., Lin, C., \& Sun, S. (2007). The impact of HIV/AIDS on families and children-a study in china. AIDS London, England, 21(8), S157. doi:10.1097/01.aids.0000304712.87164.42 
Koenig, L. J., Nesheim, S., \& Abramowitz, S. (2011). Adolescents with perinatally acquired HIV emerging behavioral and health needs for long-term survivors. Current Opinion in Obstetrics \& Gynecology, 23(5), 321-327. doi:10.1097/GCO.0b013e32834a581b

Lee, C.-L., \& Johann-Liang, R. (1999). Disclosure of the Diagnosis of HIV/AIDS to Children Born of HIV Infected Mothers. AIDS Patient Care and STDs, 13(1), 4145.

Leonard, L., \& Ellen, J. (2008). "The sotry of my life": AIDS and 'autobiographical Ocassions'. Qual Sociol, 31, 37-56.

Lesch, A., Swartz, L., Kagee, A., Moodley, K., Kafaar, Z., Myer, L., \& Cotton, M. (2007, July). Paediatric HIV/AIDS disclosure: towards a developmental and processoriented approach. AIDS care, 19(6), 811-816. doi:10.1080/09540120601129301

Li, L., Wu, S., Wu, Z., Sun, S., Cui, H., \& Jia, M. (2006). Understanding family support for people living with HIV/AIDS in Yunnan, China. AIDS and Behavior, 10(5), 509-517. doi:10.1007/s10461-006-9071-0

Marin, G. (1989). AIDS prevention among Hispanics: Needs, risk behaviors, and cultural values . Public Health Reports, 104(5), 411-415.

Michaud, P., Suris, J., Thomas, R., Gnehm, H., Cheseaux, J., \& MoCHIV. (2010). Coping with an HIV infection. Swiss Med Wkly, 140(17-18), 247-253.

Mitchell, C., \& Linsk, N. L. (2004). A multidimensional conceptual framework for understanding HIV/AIDS as a chronic long-term illness. Social Work, 49(3), 469477.

Mellins, C. C. A. (2002). Patterns of HIV status disclosure to perinatally HIV-infected children and subsequent mental health outcomes. Clinical Child Psychology and Psychiatry, 7(1), 101-114.

National Institute of Allergy and Infectious Diseases (NIAID). (1994). Executive Summary: Abstract ACTG 076. A Phase III Randomized, Placebo-Controlled Trial to Evaluate the Efficacy, Safety and Tolerance of Zidovudine (ZDV) for the Prevention of Maternal-Fetal Transmission. National Institutes of Health. Retrieved from: http://aidsinfo.nih.gov/news/102/executive-summary-abstractactg-076-a-phase-iii-randomized-placebo-controlled-trial-to-evaluate-theefficacy-safety-and-tolerance-of-zidovudine-(zdv)-for-the-prevention-ofmaternal-fetal-transmission.

Noland, C. (2006). Listening to the sound of silence: Gender roles and communication about sex in Puerto Rico. Sex Roles, 55, 283-294. doi:10.1007/s11199-006-9083-2 
Ortíz-Torres, B., Serrano-García, I., \& Torres-Burgos, N. (2000). Subverting culture: Promoting HIV/AIDS prevention among Puerto Rican and Dominican women. American Journal of Community Psychology, 28(6), 859-881.

Pérez-Perdomo, R., Pérez-Cardona, C. M., \& Suárez-Pérez, E. L. (1999). Epidemiology of pediatric AIDS in Puerto Rico: 1981-1998. AIDS Patient Care and STDs, 13(11), 651-658.0

Persson, A., \& Newman, C. (2012). When HIV-positive children grow up: A critical analysis of the transition literature in developed countries. Qualitative Health Research, 22(5), 656-667.

Pinzón-Iregui, M. C., Beck-Sagué, C. M., \& Malow, R. M. (2012). Disclosure of their HIV status to infected children: A review of the literature. Journal of Tropical Pediatrics, 59(2), 84-89. doi:10.1093/tropej/fms052

Puerto Rico Department of Health. (2014). Puerto Rico HIV \& AIDS surveillance Summary: Cumulative HIV \& AIDS case diagnosed as of January 2014. San Juan, Puerto Rico.

Puerto Rico Department of Health. (2014). Puerto Rico HIV surveillance Summary: Cumulative HIV case diagnosed as of January 2014. San Juan, Puerto Rico.

Reiss, J. G., Gibson, R. W., \& Walker, L. R. (2005). Health care transition: Youth, family, and provider perspectives. Pediatrics (Evanston), 115(1), 112. doi:10.1542/peds.2004-1321

Rodríguez, J. (2009). Puerto Rican adolescents striving to live a normal life with HIV: A grounded theory. (Doctoral dissertation). Retrieved from https://www.nursing.arizona.edu/Library/Rodriguez_Janet_Dissertation.pdf

Sanders, L. (2008, Feb). Women's voices: The lived experience of pregnancy and motherhood after diagnosis with HIV. Journal of Association of Nurses in AIDS Care, 19(1), 47-57. doi:10.1016/j.jana.2007.10.002

Sherman, B. F., Bonanno, G. A., Wiener, L. S., \& Battles, H. B. (2000). When children tell their friends they have AIDS: Possible consequences for psychological wellbeing and disease progression. Psychosomatic Medicine, 62(2), 238-247.

Sutcliffe, C. G., Van Dijk, J. H., Bolton, C., Persaud, D., \& Moss, W. J. (2008). Effectiveness of antiretroviral therapy among HIV-infected children in subSaharan Africa. The Lancet infectious diseases, 8(8), 477-489.

UNAIDS \& WHO. (2011). UNAIDS World AIDS Day Report. 
Valenzuela, J. M., Buchanan, C. L., Radcliffe, J., Ambrose, C., Hawkins, L. A., Tanney, M., \& Rudy, B. J. (2011). Transition to adult services among behaviorally infected adolescents with HIV--A qualitative study.Journal of Pediatric Psychology, 36(2), 134-140. doi:10.1093/jpepsy/jsp051

Varas-Díaz, N., Serrano-García, I., \& Toro-Alfonso, J. (2005, February). AIDS-related stigma and social interaction: Puerto Ricans living with HIV/AIDS. Qualitative Health Research, 15(2), 169-187. doi:10.1177/1049732304272059

Vijayan, T., Benin, A. L., Wagner, K., Romano, S., \& Andiman, W. A. (2009). We never thought this would happen: Transitioning care of adolescents with perinatally acquired HIV infection from pediatrics to internal medicine. AIDS Care, 21(10), 1222-1229. doi:10.1080/09540120902730054

Wiener, L., Kohrt, B., Battles, H., \& Pao, M. (2011). The HIV experience: Youth identified barriers for transitioning. Journal of Pediatric Psychology, 36(2), 141154. doi:10.1093/jpepsy/jsp129

Wiener, L., Mellins, A., Marhefka, S., \& Battles, H. (2007). Disclosure of an HIV diagnosis to children: History, current research, and future steps. J Dev Behav Pediatr, 28(2), 155-166.

Zorrilla, C. D., Rabionet, S. E., Mosquera, A., \& Ramirez de Arellano, A. B. (2012). Biomedical HIV Prevention Strategies: State of the Art and Implications for Public Health Policy in the Caribbean. Puerto Rico Health Sciences Journal, 31(3), 170-179.

Zorrilla, C. D., Tamayo, V., Febo, I., Santiago, L. E., Diaz, C., Salabarria, I., .. . Perez, E. (2007). Reduction in the perinatal HIV transmission: The experience at the Maternal Infant Studies Center and GAMMA Projects at University of Puerto Rico. Puerto Rico Health Sciences Journal, 26(4), 329-335. 


\section{STUDY DESIGN AND METHODOLOGY}

This qualitative phenomenological study seeks to explore the experience of youth living with HIV in Puerto Rico due to perinatal transmission, and the meaning these youths give to their life experience. The study followed an interpretative phenomenological analysis as formulated by Jonathan Smith.

\section{Methodological Framework}

Interpretative phenomenological analysis (IPA), as described by Smith, Flowers and Larkin (2009), combines three philosophical currents: phenomenology, hermeneutics and ideography. These are briefly summarized in order to provide a synopsis of the philosophical and epistemological foundation that underlies IPA's analytical procedures and how they applied to the research study. It is important, however, to point out that IPA provides a method for analysis and in so doing selects from these various but interrelated perspectives. IPA is based on the original ideas of the philosophers Edmund Husserl, Martin Heidegger and Maurice Merleau-Ponty.

\section{Philosophical Currents}

Phenomenology. Phenomenology is a philosophical current that seeks to understand a phenomenon from the perspective of the individuals who experienced it (Lester, 1999; Creswell, 2007; Smith et al., 2009). Essentially, phenomenology is "the philosophical study of 'being' and or experience” (Larkin, 2012).

The foundation of phenomenology is based on the ideas of German mathematician Edmund Husserl. He was interested in understanding certain phenomenon from the perspective of the people who had the experiences (Chan, Fung \& Chien, 2013; Smith et al., 2009). Smith et al. (2009) observe that, for Husserl, 
phenomenology involves the careful examination of human experience. They further note that Husserl is interested in understanding the means by which individuals "accurately know their own experience of a certain phenomenon” (Smith et al., 2009). According to Husserl, individuals experience a phenomenon by identifying the essential features of the experience. The essence of an experience is the thing that makes it what it is; for example, the things that make a house a house and not a restaurant (Smith et al., 2009). Husserl stated that we need to step out of our own everyday experiences and our preconceived knowledge in order to understand another's life experiences and grasp the essence of these, a process known as "bracketing” (Husserl, 1931; LeVasseur, 2003, Larkin, 2012).

The phenomenology current of IPA will contribute to my exploration of the contextual "experience" of participants related to the shared "phenomena" of:

- acquiring HIV infection thorough perinatal transmission

- being a youth living with HIV

- receiving comprehensive health care in the UPR Pediatric HIV/AIDS Research Program, and

- living during the past two or three decades in Puerto Rico

Hermeneutics. Hermeneutics is the theory of interpretation. Husserl's seminal concepts led to a further revision of his work, in particular the notion of bracketing and the eventual formalization of hermeneutics. For example, Heidegger and Merleau-Ponty argued that Husserl's reduction (bracketing) was not possible because our life experience cannot be detached from us (Kock, 1995 as cited in Chan et al., 2013); it is from this experience that we come to understand the world. The philosopher Jean-Paul Sartre 
emphasized that the things that are absent are as important as the ones that are present when individuals make sense of the world. He stated that "an existing individual is constantly in the process of becoming;" he believed that the "self is not a pre-existing unit to be discovered, but rather an ongoing project to be unfurled” (Smith et al., 2009, p. 19).

In proposing IPA, Smith et al. (2009) recognize the contrasting views of these authors, while they recommend bracketing when conducting data collection and analysis they also realize its limitations. They therefore suggest that the researcher acknowledge individual preconceptions and experiences that may render "total” bracketing impossible. This position is further evidenced in hermeneutics, which also underlies IPA's framework.

Hermeneutic philosophers argue that we cannot detach ourselves from our own prejudices and biases in the process of interpretation and understanding (Schwandt, 1994). Interpretations are context-dependent. Because they are interwoven with our preconceptions they can change every time an interpretation is made (Smith et al., 2009). Interpretation is a dynamic process and IPA may involve double and even triple hermeneutics.

By approaching the information provided by the participants from a hermeneutic perspective, I was able to interpret their experience based on the context they have experienced and also in the context in which he/she narrated their interpretation. The interviewer, as well, interpreted participants' experiences based on her own context. The researcher considered participants' interpretation of their experiences with an open mind allowing themes to emerge and data to "speak". The process is also holistic because each 
of the participants is seen as a whole person, not only as an HIV patient. The researcher searched for connections, similarities and differences among all of them; this helped to better understand and interpret the phenomenon.

Ideography. Interpretative phenomenological analysis proponents propose that their approach is ideographic because it has to do with the particular and is specific rather than general. IPA aims to understand "how particular experiential phenomena have been understood from the perspective of particular people, in a particular context” (Smith et al., 2009, p. 29). This ideographic perspective of approaching the data is the cornerstone of studies that rely on the IPA framework. This component allows for the discovery and documentation of the voices of participants from which the researcher aims to learn and understand the phenomena. Based on the philosophical currents of IPA, I proposed the following framework.

\section{Graphic Representation of the Theoretical Framework}

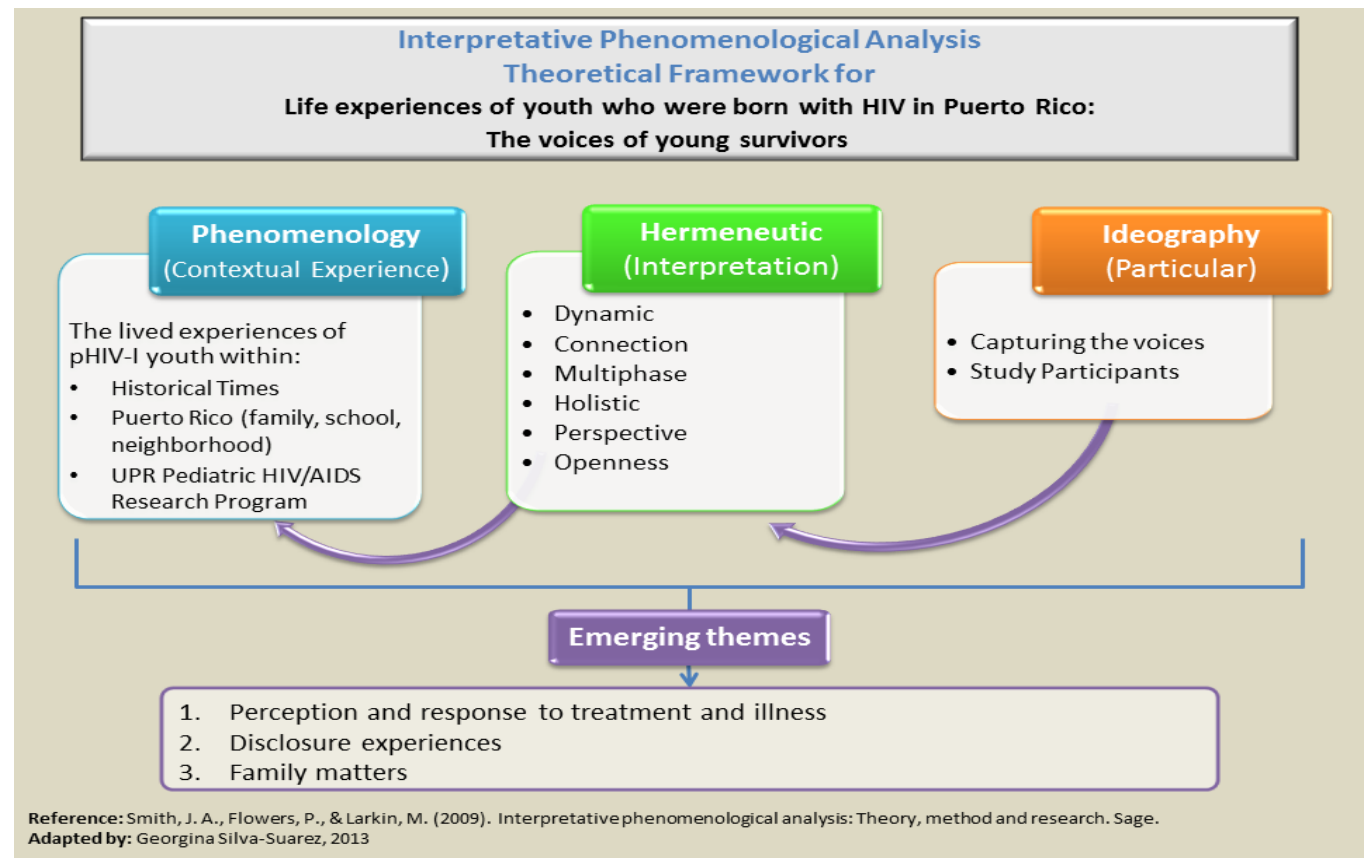


These themes share unique characteristics all of them have multiple phases, which evolve and are redefined across time. The methodological approach of IPA will allow study these topics from a dynamic perspective. One of the major contributions of this study is that we will be able not only to understand these topics from the perspective of the study participants, but also learn how these topics evolve over time due to life experiences or developmental processes of the study participants.

\section{Institutional Review Board}

The University of Puerto Rico’s Institutional Review Board (IRB) approved the study's procedure and documentation (i.e. informed consents in Spanish and English, proposal and protocol, human subject training certificates, and questions guide) in June 2012. The same procedure and documentation including translated informed consent form were submitted to Florida International University's IRB in September 2012 and approved in October 2012. Refer to Appendix 1 for letters of approval.

\section{Data Collection}

The in-depth interview was selected as a suitable method to collect participants' life experiences. The aim of the interview was to enable participants to tell their stories in their own words, exploring the nature and meaning that participants gave to their everyday life experiences. Interviewing is a powerful way to try to understand our fellow human beings (Fontana \& Frey, 1998). It is also a way to generate empirical data of the social world (Holstein \& Gubrium, in Silverman, 1997). The interview is an interactive process in which both an interviewer and an interviewee take part. In that interaction, both parties are considered knowledgeable and all points of view should be respected. The ultimate goal is to try to understand members of society without imposing any $a$ 
priori categorizations (Fontana \& Frey, 1998). An interview schedule or guide is recommended in IPA research studies to facilitate the interview process (Smith et al., 2009). The methodological steps of IPA were followed in developing the interview question guide, as described below.

Creating the Interview Guide. In order to explore the acceptability and pertinence of the topic, conversations with a physician, a social worker, and 5 patients took place a year prior to the start of the study (Fall 2011). All individuals involved in the conversation agreed to collaborate with the study and thought that it was pertinent and necessary.

A set of open-ended questions was developed. These addressed the main goal and research question of the study, which was to examine how perinatally-infected youth describe the impact of HIV on their lives. A list of open-ended question was then categorized into three major areas: personal, social, and medical.

The interview guide was assessed by experts in perinatal HIV-infection (including a pediatrician, a social worker, and a public health specialist); their recommendations were incorporated in the question guide. Some of their recommendations regarded the order and wording of the questions. The question guide was piloted with a potential participant. The participant reported feeling comfortable during the interview, and thought that the questions were very appropriate and pertinent for HIV perinatallyinfected youth from Puerto Rico. As such, no changes were made to the interview guide after conducting the pilot.

The interview guide was used as a tool to guide the discussion rather than as a strict questionnaire eliciting answers. Participants were allowed to speak freely of their 
experience as youth living with HIV due to perinatal transmission and the researcher probed with additional questions when necessary to maintain the conversation flow. See Appendices 2 and 3 for the full version of the interview guide.

\section{Site}

Study participants were recruited through the UPR Pediatric HIV/AIDS Research Program. The Program was created in 1986 to provide services to children diagnosed with AIDS (Zorrilla et al., 2007). The services the UPR Pediatric HIV/AIDS Research Program offers to patients and their families include social work interventions, free vaccinations, specialized laboratory testing, and referrals to sub-specialists. These services are provided by an inter-disciplinary team. In addition, because the UPR Pediatric HIV/AIDS Research Program has been part of the Pediatric AIDS Clinical Trials Group, children, adolescents and caregivers have had the opportunity to voluntarily participate in clinical trials and other research studies.

Currently, the UPR Pediatric HIV/AIDS Research Program provides comprehensive care to 45 children and adolescents living with HIV; of these, $90 \%$ acquired HIV perinatally. Because the unit has a more than 20-year history, some who began receiving services as infants or young children have now entered a different stage in their development, having "aged in place” and maintained their affiliation with the service provider. Nevertheless, very little has been published about the experiences of those children who have grown to adulthood within the programs offered by the UPR Pediatric HIV/AIDS Research Program. Although the findings of this study cannot be generalized, these experiences can help to inform public health practices and services targeted to this population (perinatally HIV-infected adults) in Puerto Rico and other 
regions with large populations of Puerto Ricans and other Latinos, such as New York City and Florida.

\section{Sample Selection}

Interpretative phenomenological analysis requires purposeful sampling, primarily to guarantee the ideography component of it. This sampling method seeks to select information-rich cases to study in depth (Patton, 1990). Powerful or rich cases are those "from which one can learn a great deal about issues of central importance to the purpose of the research” (Patton, 1990).

In an IPA research study, participants are carefully selected and the sample size is often small. It can be as small as one or as large as ten, although it is recommended to keep the sample size small in order to focus on the quality of the interview process rather than on the quantity (Smith et al., 2009).

Participants of the study were 20 young adults living with HIV due to perinatal transmission who participate or have participated in the UPR Pediatric HIV/AIDS Research Program. The study included women and men between the ages of 18 to 30 years who live in Puerto Rico.

Inclusion and Exclusion Criteria. Participation in the study was limited to persons who were:

- Living with HIV infection due to perinatal transmission

- UPR Pediatric HIV/AIDS Research Program patients or former patients

- $\quad$ Between the ages of 18 to 30 years

- Knowledgeable about their HIV status and willing to share their life experience as individuals who were perinatally-infected with HIV 
The exclusion criteria for the study were:

- $\quad$ Severe cognitive disabilities

- In current custody of Puerto Rico Department of the Family (The Department of the Family in Puerto Rico does not allow children or youth under their custody to participate in any research studies).

Recruitment Process. The UPR Pediatric HIV/AIDS Research Program’s staff physician, nurses, and/or social workers determined whether or not patients met the inclusion criteria when they visited the clinic for their routine appointments. When potential participants met the inclusion criteria, the UPR Pediatric HIV/AIDS Research Program staff invited them and their parent or guardian, when appropriate (i.e., when the potential participant was less than 21 years old), to participate in the research study. After patients (and their parents, if appropriate) agreed to participate, they were contacted by telephone by the researcher -Georgina Silva-Suárez- who explained to them the purpose of the study and gauged their willingness to participate in an interview in which their life experiences as perinatally-infected youth living with HIV were going to be explored. Any questions or concerns were clarified during the telephone conversation, and an interview appointment was scheduled at the convenience of participants and their parents.

On the day and time selected by the participants, a discussion of the informed consent protocol took place. Once the participants' understanding was assessed, his/her signature was obtained. The interview began following the signing of the informed consent form. The interview lasted between 45 minutes and 90 minutes; a snack and a 
beverage were provided at the beginning of the process. The entire study participation consisted of this interview.

Interviews were conducted in a non-judgmental, respectful environment at the Maternal Infant Study Center (CEMI, for its Spanish acronym), a sister clinic to the UPR Pediatric HIV/AIDS Research Program that also provides services to people living with HIV. CEMI is located on the Medical Sciences Campus, next to the Pediatric Hospital in which most UPR Pediatric HIV/AIDS Research Program participants receive their health services.

All the interviews were conducted in Spanish, the native language of both the study participants and the researcher-Georgina Silva-Suárez. After completing the interview, each participant received $\$ 50.00$ as an incentive to cover transportation, meal and other expenses for the day.

\section{Data Analysis}

All interviews were audio recorded, then transcribed by the researcher. Transcripts were sanitized by removing any comments that may have compromised confidentiality. After each interview was transcribed and sanitized, it was translated into English by a graduate research assistant who is proficient in both English and Spanish and immersed in Puerto Rican culture. It should be noted however, that the original Spanish text was used in conducting the qualitative analysis; thus avoiding a third level of text interpretation as indicated in qualitative procedures.

Transcripts were examined individually. Following the steps proposed by Smith et al. (2009), the researcher read and re-read each of the transcripts making the participant the focus of the analysis. The second step was initial noting. Transcripts 
were examined in an open-minded, systematic, and exploratory way. Initial observations were recorded in the margin of each transcript. After completing this step, a table summarizing the observations and the annotations was created. This aimed to produce a comprehensive and detailed set of notes and comments, as recommended by Smith et al. (2009).

Emerging themes were identified based on the previous work in the aforementioned steps (Smith et al., 2009). This theme-identification step sought to reduce the amount of information, maintaining the interrelationships, connections, and patterns among the notes. The emerging themes that were identified were: medication adherence, and therapeutic and adverse effects, myths, the meaning of HIV infection, anxiety and stress, stigma, issues of normality, bonds, tragedy and sadness, and the selfcharacterization as “fighters” and “challengers.”

After identifying the emerging themes, the researcher identified connections among these themes (the fourth step of the analysis). Themes that fit together were grouped into major themes: (1) perception and response to treatment and illness, particularly their lived experiences with ART; (2) disclosure experiences; and (3) family matters.

Multiple Coding (Inter-Rater Reliability). In order to confirm the themes that emerged, 10 of 20 interview transcripts were assessed by two professionals, one in the area of human rights and the other in public health. Both identified major themes from the same 10 transcripts. The emerging themes were then cross-checked by each professional. When this procedure revealed discrepancies in topics, the coders clarified and discussed other possible interpretations, refined or created a new code or theme. 
Software. NVIVO 10 (QSR International, Burlington, USA) qualitative analysis software (QSR 2014) was used to facilitate the systematic processing of the information from the in-depth interviews. All of the interview transcriptions were imported into NVIVO and the coding process was performed using the software. 


\section{References}

Chan, Z. C. Y., Fung, Y., \& Chien, W. (2013). Bracketing in phenomenology: Only undertaken in the data collection and analysis process. The Qualitative Report, 18(59), 1-9.

Creswell, J. W. (2007). Qualitative inquiry \& research design: Choosing among five approaches (2nd ed.). Thousan Oak, California: Sage Publication, Inc.

Fontana, A., \& Frey, J. H. (1998). The interviewing: the art of science. In N. K. Denzin, \& Y. S. Lincoln (Eds.), Collecting and interpreting qualitative materials (pp. 4778). Thousand Oaks, Californa: Sage Publications, Inc.

Holstein, J. A., \& Gubrium, J. F. (1998). Active interviewing. In D. Silverman (Ed.), Qualitative Research: Theory, Method and Practice. Thousand Oaks, California: SAGE Publications, Inc.

Husserl, E. (1931). Ideas: General introduction to pure phenomenology. New York: Collier: W. R. Boyce Gibson, Trans.

Larkin, M. (2012). Interpretative phenomenological analysis - introduction. Prezi web presentation. Retrieved from http://prezi.com/dnprvc2nohjt/interpretativephenomenological-analysisntroduction/?auth_key=3d2c098e0db0a31ea05f2d9f60148ed5144e6d06

Lester, S. (1999). An introduction to phenomenological research. Stan Lester Developments, 1-4. Retrieved on March 2013, from: http://www.sld.demon.co.uk/resmethy.pdf accessed

LeVasseur, J. J. (2003). The problem of bracketing in phenomenology. Qualitative Health Research, 13(3), 408-420. doi:10.1177/1049732302250337

Patton, M. Q. (1990). Qualitative evaluation and research methods. Thousand Oaks, CA: Sage Publications, Inc.

Schwandt, T. A. (1994). Three Epistemological Stances for Qualitative Inquiry: Interpretitivism, Hermeneutics and Social Constructivism. In N. Denzin, \& Y. Lincoln (Eds.), In Handbook of Qualitative Research (2000), pp. 189-214 Key: citeulike:5377649 (2nd ed.). United Kingdom: Sage Publications, Inc.

Smith, J., Flowers, P., \& Larkin, M. (2009). Interpretative Phenomenological Analysis: Theory, Method and Research. Thousand Oaks, California: SAGE, Inc.

Zorrilla, C. D., Tamayo, V., Febo, I., Santiago, L. E., Diaz, C., Salabarria, I., .. . Perez, E. (2007). Reduction in the perinatal HIV transmission: The experience at the Maternal Infant Studies Center and GAMMA Projects at University of Puerto Rico. Puerto Rico Health Sciences Journal, 26(4), 329-335. 


\section{FIRST MANUSCRIPT}

\section{A Tough Pill to Swallow: The Meaning of ART for Puerto Rican Perinatally HIV- Infected Youth}

Georgina Silva-Suárez,,$_{1}$ Elena Bastida, ${ }_{1}$ Silvia E. Rabionet, $, 2,3$ Consuelo Beck-Sagué, 1 H. Virginia McCoy, 1 and Carmen D. Zorrilla, 3 ${ }_{1}$ Florida International University, Miami, FL, USA

${ }_{2}$ Nova Southeastern University, Ft. Lauderdale, FL, USA

${ }_{3}$ University of Puerto Rico, Medical Sciences Campus

\section{Corresponding Author:}

Georgina Silva-Suárez, MPHE, Florida International University, Robert Stempel College of Public Health and Social Work, Miami, FL, 33199,USA

Email: gsilv010@fiu.edu

\section{Acknowledgments}

I express my sincere gratitude to my dissertation committee for their guidance and dedication: Dr. Elena Bastida, Dr. Consuelo Beck-Sagué, Dr. H. Virginia McCoy, Dr. Mario De la Rosa and Dr. Silvia Rabionet. I would like to thank Dr. Carmen Zorrilla, Dr. Irma Febo, the staff of the University of Puerto Rico (UPR) Pediatric HIV/AIDS Research Program and CEMI and the Puerto Rico Mentoring Institute for HIV and Mental Health Research for supporting this study. Also, I would like to thank Dr. Annette B. Ramírez de Arellano, and my research assistant, Ana Carolina Arboleda, for their invaluable contributions to the study. I thank the Florida International University Graduate School for awarding me a Dissertation Year Fellowship. 


\section{Declaration of Conflicting Interests}

The authors declare no potential conflicts of interest with respect to the research, authorship, and/or publication of this article.

\section{Funding}

This research study was funded by the National Institute of Mental Health (NIMH) through the Puerto Rico Mentoring Institute for HIV and Mental Health Research (grant \# 1R25MH083617) and Florida International University, Dissertation Year Fellowship.

\section{Biographical Information}

Georgina Silva-Suárez, MPHE, is a health educator and graduate student at Florida International University, Robert Stempel College of Public Health and Social Work Elena Bastida, PhD, is a professor in the Department of Health Promotion and Disease Prevention at the Robert Stempel College of Public Health and Social Work at Florida International University.

Silvia E. Rabionet, EdD, is an associate professor in the College of Pharmacy at Nova Southeastern University and in the School of Public Health at the University of Puerto Rico, Medical Sciences Campus.

Consuelo Beck-Sagué, MD, is an assistant professor in the Department of Health Promotion and Disease Prevention at the Robert Stempel College of Public Health and Social Work at Florida International University.

H. Virginia McCoy, $\mathrm{PhD}$, is a professor in the Department of Health Promotion and Disease Prevention at the Robert Stempel College of Public Health and Social Work at Florida International University. 
Carmen D. Zorrilla, MD is a professor in the Department of Obstetrics and Gynecology at the School of Medicine of the University of Puerto Rico, Medical Sciences Campus. She is the Director of the Maternal Infant Study Center (CEMI for its Spanish acronym).

\begin{abstract}
This study used interpretative phenomenological analysis (IPA) to examine life experiences of perinatally HIV-infected (pHIV-I) youth in Puerto Rico seeking to understand the meanings and implications of antiretroviral therapy (ART) in their lives, while emphasizing the interactive and dynamic processes that underlie these experiences. Twenty in-depth interviews were conducted and audio-recorded. Interviews explored the meaning, taking of and adherence to medications. The study found that ART held a very special and particular meaning for participants who attributed their survival to this treatment. Nevertheless, the meaning they constructed around adherence to, and dependence on ART for their survival was complex and continuously evolved. As expected, meaning construction changed throughout the respondents' lives, and their various constructions evolved as they entered and exited different stages of the life course. Some questioned why they had to be medicated when they felt "good and healthy.” Throughout, they acknowledged suffering the burdens of adverse effects, multiple doses, and complex schedules and described their medication with ambivalence, as both "good and complicated." Others associated their dependence on "medications" with disfiguring adverse events, body image distortion and interference with studies and social activities. Our findings suggest that programs serving pHIV-I young adults need to carefully craft messages highlighting the importance of adherence within a broader
\end{abstract}


approach that integrates the experiential and the personal meaning construction and understanding, which is critical to how they make sense of their lives and their dependence on ART. Emotions underlying these experiences, including fear of rejection and the impact of medications on self-esteem, also need to be considered.

\section{Key words:}

Adolescents; HIV perinatally infected; Puerto Rico; antiretroviral therapy (ART); interpretative phenomenological analysis

\section{Introduction}

"No child should be born with HIV; no child should be an orphan because of HIV; no child should die due to lack of access to treatment.” These words were spoken by Ebube Sylvia Taylor, a perinatally HIV-exposed uninfected Nigerian girl (Joint United Nations Programme on HIV/AIDS [UNAIDS] 2011]). The United Nations, through UNAIDS, proposed a global strategy to reduce the numbers of new HIV infections among children by over $90 \%$ and the number of AIDS-related maternal deaths by 50\% (UNAIDS, 2013). Despite this unprecedented effort to eliminate mother-to-child HIV transmission, there are approximately 3.2 million children under 15 years of age already living with HIV worldwide (UNAIDS, 2013). Most of these infections are due to perinatal transmission (Sohn \& Hazra, 2013).

Perinatally HIV-infected (pHIV-I) youth have survived because of the development of and access to antiretroviral therapy (ART) (Hazra, Siberry, \& Mofenson, 2010). As they live longer and healthier lives, they must also face difficult and sometimes challenging experiences such as: stigma and discrimination; delayed 
disclosure of their diagnosis to them; challenges related to medication adherence; losses and resultant bereavement; poverty; adverse effects of ART, including abnormal stigmatizing physical appearance and body changes; fear of rejection; and secrecy around their HIV diagnosis (Blasini et al., 2004; Hogwood, Campbell, \& Butler, 2012; Koenig, Nesheim \& Abramowitz, 2011).

Research studies have found that "pediatric HIV patients are more prone to distress than their uninfected peers," in addition to experiencing physical pain, anxiety, and being less socially active and successful academically than uninfected counterparts (Brown \& Lourie, 2000). Given these conditions, the support of friends is essential to help them cope with their health situation (Sherman, Bonanno, Wiener, \& Battles, 2000).

One of the many ways in which pHIV-I youth differ from their peers is their daily dependence on medications necessary for their health and survival. While youth with other chronic conditions (e.g. diabetes, cancer, and obesity) may also face similarly stigmatizing situations resulting from adverse effects of these treatments, ---e.g. hair loss from chemotherapy, obesity due to "strict control" insulin regimens--- pHIV-I youth endure a disease that is intrinsically stigmatizing because of its association with homosexuality, injection drug use, commercial sex work, and other "undesirable" behaviors workers (Varas-Díaz et al., 2004). As pHIV-I children become adolescents and young adults, they become indistinguishable from "behaviorally"-infected persons. As a result, they cease to enjoy the protected status of "innocent victims" destined for early death reserved for infants and young children infected perinatally or by blood products (Nicholas \& Abrams, 2002). Consequently, pHIV-I adolescents often conceal 
their ART use, lie to their friends about it, or fail to take it altogether (Michaud et al., 2010).

While the patients are children, their parents or caregivers are responsible for their treatment (Hazra et al., 2010). As the children grow and enter adolescence, they assume responsibility for taking medication. Many researchers have shown that adherence to ART often deteriorates during this transition for a variety of reasons, including forgetfulness, stigma, problems with body image, and a desire to be normal (Blake, Robley, \& Taylor, 2012; Hazra et al., 2010; Michaud et al., 2010). Perinatally HIVinfected youth find it difficult to take medications because they are asymptomatic and may not fully understand the importance of strictly following their regimen. In addition, for some taking medications becomes a negative reminder of their health situation and is associated with being sick (Blake et al., 2012; Vijayan, Benin, Wagner, Romano, \& Andiman, 2009).

Research on ART has focused on adherence and virologic outcome; some have explored the "relationship between adherence and other predictors” (Arrivillaga, Martucci, Hoyos, \& Arango, 2013). Others have relied on clinical data and medical record review without consulting with those affected by the condition under investigation (Persson \& Newman, 2012). Few have fully considered the perspectives of pHIV-I youth regarding ART and adherence.

Qualitative phenomenological studies provide an opportunity to understand a phenomenon from the perspective of the individuals who experience it (Creswell, 2007; Lester, 1999; Smith, Flowers, \& Larkin, 2009). This method allows researchers to learn from the population itself. More specifically, it explores how a person experiences the 
phenomenon and what can be learned from it. Within phenomenology, interpretative phenomenological analysis (IPA) aims to “understand the participant’s world and describe what it is like,” (Larkin, Watts \& Clifton, 2006, p.104) always emphasizing "what it means” for the participant or how he/she makes sense of a particular situation (Larkin et al., 2006).

We used interpretative phenomenological analysis, a qualitative framework that aims to explore how people make sense of their everyday life experiences (Smith et al., 2009), to understand the implications, meaning, and dynamics underlying ART use in the lives of pHIV-I youth in Puerto Rico. It aimed to capture the voices and everyday experiences of adolescents and young adults living with HIV in Puerto Rico to gain much needed insight and information about the meaning of this journey and the experiences resulting from being a pHIV-I youth living with HIV in Puerto Rico at a particular juncture in their lives. The data obtained through the application of a phenomenological approach and interpreted using the IPA process is expected to increase understanding of these youths' trajectories and inform the design of care and processes involved in responding to their unique needs. By probing their experiences and the meanings they ascribe to them, this effort should yield data valuable to practitioners, counselors and others providing services to this population, and may be useful in identifying and assuaging their concerns, addressing their anxieties, and ensuring their adherence to treatment.

Leonard and Ellen (2008, p.38) have suggested that presenting life experiences “perform the more public function of activating communities of listeners and promoting advocacy and awareness about their needs.” Currently, the possibility of eliminating 
perinatal transmission of HIV has spurred welcome interest in this area (UNAIDS, 2011). However, this has also tended to reduce the visibility of pHIV-I persons, and possibly the understanding that their needs are different from those of behaviorally-infected people. The current effort should therefore boost advocacy for this population (Fair \& Albright, 2012).

\section{Methods}

This study used interpretative phenomenological analysis, a qualitative framework that aims to explore how people make sense of their everyday life experiences (Smith et al., 2009). Phenomenological research seeks to examine an experience or phenomenon "the way it occurs and in its own terms" (Smith et al., 2009, p. 12).

IPA approach allowed to gather the vivid recall of participants lived experience regarding their medication intake and what it meant to them. However, it is recognized that what they believe to "vividly recall” has been altered by the passing of time and repeatedly transformed in their memory recollections of their lived experiences with ART. And thus this "vivid recall" is at best a reconstruction of that experience. For purposes of the material presented here, the exact details of the event are of little importance, however, the reconstruction of this experience is very much at the center of the discussion. It is not the accuracy of the event itself that is of importance here, but how this experience, however recalled, reconstructed or transformed many times over throughout the years has shaped and continues to shape the current unfolding of their lives. 


\section{Sample Selection}

Purposeful sampling was used to recruit study participants. This sampling method seeks to select information-rich cases to study in depth (Patton, 1990). Powerful or "rich" cases are those "from which one can learn a great deal about issues of central importance to the purpose of the research" (Patton, 1990, p.169). The in-depth interview was selected as the method most suitable to collect participants' life experiences. Study eligibility criteria were being: current or former patients of the UPR Pediatric HIV/AIDS Research Program; pHIV-I; aged 18-30 years with knowledge of their HIV status, and; willing to share their life experiences.

\section{Recruitment}

The UPR Pediatric HIV/AIDS Research Program’s staff physicians, nurses, and/or social workers determined whether or not patients met the inclusion criteria when they attended the clinic for their routine visits. When potential participants met the inclusion criteria, the UPR Pediatric HIV/AIDS Research Program staff invited them (and their parent or guardian, if the patient was under 21 years old), to participate in the research study. After participants and their parents agreed to the interview, they were contacted by telephone by the first author, who explained the purpose of the study and gauged their willingness to participate in an interview to explore their life experiences as pHIV-I youth living with HIV.

Questions or concerns were clarified during the telephone conversation and an interview appointment was scheduled. Participants and their parents or guardians (when needed) gave written informed consent. 


\section{Interview Guide}

A set of open-ended questions was developed (see Appendix A). These addressed the main goal and research question of the study, which was to examine how pHIV-I youth describe the impact of HIV and ART in their lives. In keeping with the IPA framework, the questions sought to elicit both the respondents' experiences with certain phenomena and how they interpreted these phenomena. Once developed, the list of open-ended questions was subdivided into three major thematic areas: personal, social, and medical.

The interview guide was assessed by a group of experts on perinatal HIV infection; the group included a pediatrician, a social worker, and a public health specialist. Group recommendations were incorporated into the interview guide. Some of the experts' observations informed the ordering and wording of the questions. The interview guide was piloted with a potential participant who reported feeling comfortable during the interview and thought that the questions were appropriate and pertinent for pHIV-1 youth in Puerto Rico. No changes were made after conducting the pilot. The interview guide included questions regarding medication, medication intake, and adherence. We sought to learn how participants made sense of these various experiences in their own words.

The Institutional Review Boards (IRBs) of the Florida International University and the University of Puerto Rico Medical Sciences Campus evaluated and approved the study protocol. 


\section{Data Collection}

Twenty pHIV-I women and men between the ages of 18 to 30 years old were recruited and interviewed for 45 to 90 minutes. Interviews were conducted in a nonjudgmental, respectful environment at the Maternal Infant Study Center, a sister clinic to the UPR Pediatric HIV/AIDS Research Program that also provides services to people living with HIV. After completing the interview, each participant received a monetary incentive to cover transportation and other expenses associated with study participation.

All interviews were conducted in Spanish, the native language of the study participants and first author. All interviews were audio recorded, then transcribed by the first author. Transcripts were sanitized by removing any comments that may have compromised confidentiality. A graduate research assistant, immersed in Puerto Rican culture and proficient in English and Spanish, translated all interviews. ${ }^{1}$ The original Spanish text was used in conducting the qualitative analysis avoiding a third level of text interpretation, as indicated in qualitative procedures.

\section{Data Analysis}

Transcripts were examined individually. Following the steps proposed by Smith et al. (2009), the researchers read and re-read each of the transcripts establishing the participant as the focus of analysis. Transcripts were examined in an open-minded, systematic, and exploratory manner. Initial observations were recorded along the margins of each transcript. In addition to the first author, transcripts were read by at least two other members of the research team and contributors to this paper. Passages from the

\footnotetext{
${ }^{1}$ Four of the authors are native Spanish speakers. Each independently read and selected Spanish transcripts and cross validated the English translation.
} 
interviews were then discussed with other team members in relation to situation and meaning construction, as suggested by the IPA approach.

The first exploratory stage of the analysis identified approximately 40 themes. These were narrowed down or consolidated according to the following criteria: (1) their recurrence within and across cases (how often they were mentioned); (2) their relevance to care and treatment; (3) the relationship across themes.

To understand the meaning that participants constructed when talking and introspectively examining their life experiences with ART, eleven interrelated and connected themes were selected. These were: feelings about medication; medication "meaning”, intake, adherence, and therapeutic and adverse effects; feeling about information withholding and deception by caregivers (betrayal); consequences of knowing their diagnosis, fear of rejection, disclosure-meaning during childhood, mental health, and family support. Figure 1 presents a diagram indicating the interconnections among these eleven themes, as well as how they were inserted within the four broader dimensions that emerged from the narratives that participants constructed while describing their lived experience with ART. Each of these four dimensions is used below in organizing the data analysis and in illustrating the findings. 
Figure 1. Patterns and Connections Among Themes That Emerged During Phenomenological Analysis

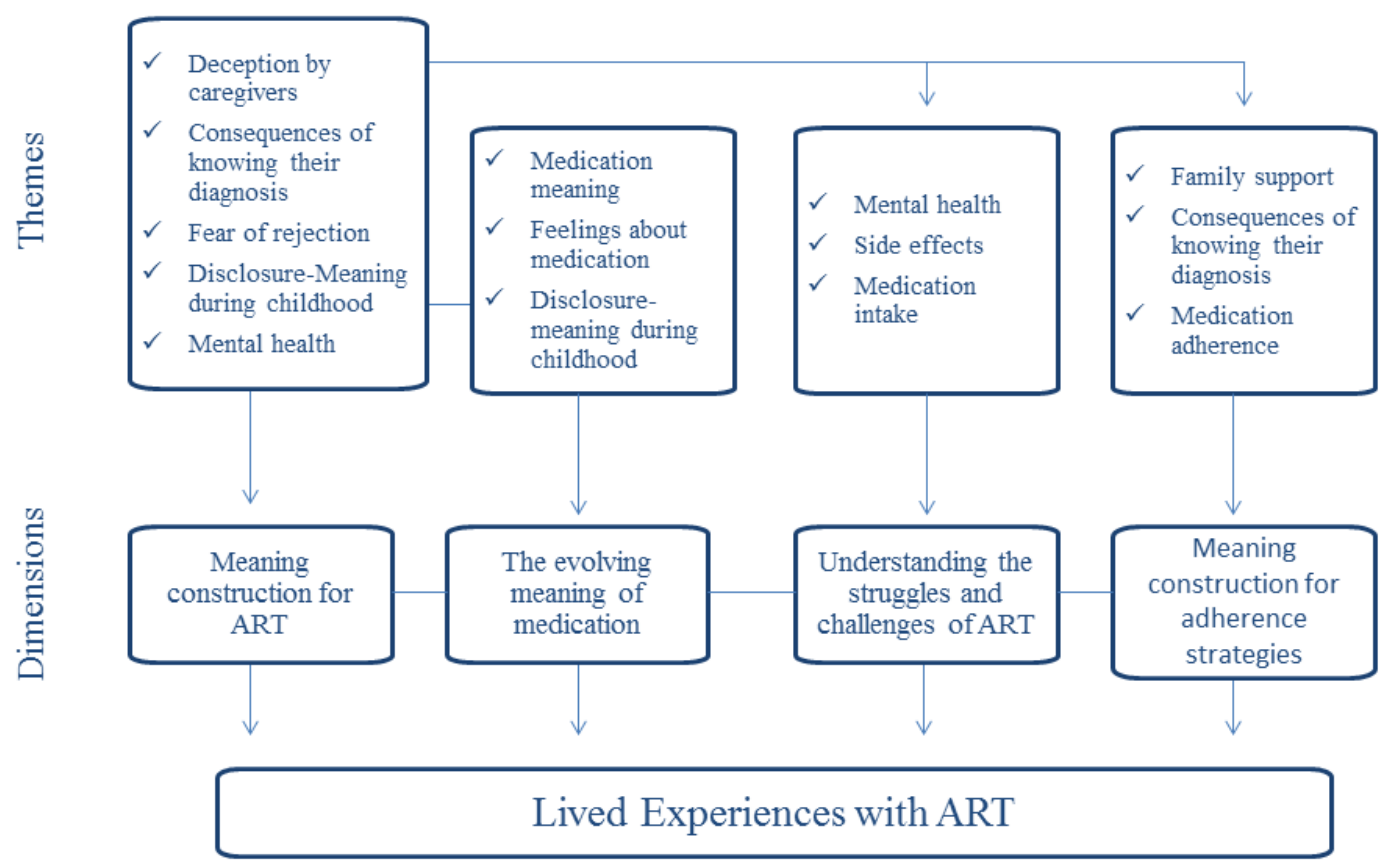

\section{Multiple Coding (Inter-Rater Reliability)}

To confirm the themes that emerged, 10 of 20 interview transcripts were assessed by two professionals, one in the area of human rights and the other in public health. Both identified major themes from the same 10 transcripts. The emerging themes were then cross-checked by each professional. When this procedure revealed discrepancies in topics, the coders clarified and discussed other possible interpretations, refined or created a new code or theme. NVIVO 10 (QSR International, Burlington, and 2014 USA) qualitative analysis software was used to facilitate the systematic processing of the information generated by the in-depth interviews. 


\section{Findings}

\section{Demographic Characteristics of the Study Population}

Of the 20 study participants, eight were male and twelve were female.

Participants ranged in age from 18 to 29 years (mean = 22 years). Eighteen had

completed high school and two had completed middle school. Only one was married at the time of the interview; sixteen were single and three were cohabitating (see Table 1).

Table 1

Sample Demographic Characteristics by Gender

\begin{tabular}{ccc}
\hline Characteristics & Male & Female \\
\hline 8 & 12
\end{tabular}

Age distribution

$\begin{array}{lll}18-19 & 3 & 2 \\ 20-21 & 2 & 4 \\ 22-23 & 1 & 4 \\ 24-25 & 1 & 1 \\ 26-30 & 1 & 1\end{array}$

Highest Academic Degree Completed

Middle School $\quad 0 \quad 2$

High School $\quad 8 \quad 10$

Marital Status

Single

$6 \quad 10$

Married

$1 \quad 0$

Cohabitating

12

Employed

Yes

$5 \quad 6$

No

36

Studying

$\begin{array}{lll}\text { Yes } & 5 & 5\end{array}$

$\begin{array}{lll}\text { No } & 3 & 7\end{array}$




\section{Lived Experiences with ART}

Understanding the phenomenon of having HIV infection due to perinatal transmission in Puerto Rico required an in-depth exploration of the lived experiences of this youth. The concept of the lived experience is very much grounded within the theoretical perspective that guides this research. It lies at the core of the qualitative methodology employed in this study and as used here it may be traced to the work of Dilthey and especially to Heidegger (Grondin, 1994; Rennie, 2007). More recently, Habermas incorporated Heidegger's hermeneutical approach in the notion of the lifeworld (Willis, 2007).

Qualitative analysis of interview narratives highlighted one prominent and shared aspect of their lives; their experience with ART. All clearly understood the dependence/survival relationship that linked them to ART and realized that adherence to ART was essential to their survival and healthy lives. Yet, as participants' narratives indicated, this relationship carried different meanings and interpretations and resulted in very individualistic accounts of their experience with ART and its particular meaning. Despite these variations, some broad categorizations could be drawn from their narratives. Four broad dimensions surfaced when referring to their personal experiences with ART. These dimensions and their respective eleven underlying themes provided a basis for understanding the lives of pHIV-I youth in Puerto Rico and the meaning ascribed to ART in their lives: (1) meaning construction for ART; (2) evolving meaning of medication; (3) understanding the struggles and challenges of ART; and (4) meaning construction for adherence strategies (see Figure 1). Participants' quotes selected to 
support each of the themes are presented under fictional names (see Appendices B, for participants’ quotes in Spanish).

\section{Meaning Construction for ART}

As revealed by participants’ narratives, medications were part of their lives since infancy; however, in most cases they did not know the reasons for their medication intake until adolescence. The daily use of ART led most study participants to begin unraveling the truth about their diagnosis. Mauro, a 21- year old single male, shared the introspective process that started during pre-adolescence as he began to question his daily intake of ART:

Eh, I started kind of doubting, at about 10 to 12 years old, because I started asking, what pill am I taking? [] I told myself "I have something, I must have something.”

In some cases, respondents began comparing themselves with other classmates and started noticing the differences between them, as described by Alonso, a married 20 year old:

See, when you're growing up you start seeing the difference: that you're on medications and other kids are not...

At this critical moment, participants began questioning their parents or caregivers about their condition. In most cases, they did not receive a concrete answer; as a result, some stopped their medication intake altogether. The underlying aim of this behavior was to force their parents or caregivers to reveal the truth behind their medication intake and health condition, as related by 19 year-old Eugenio: 
No, she wouldn't tell me, she [his mother] would make me, she would scold me and everything and I would be like, “I won't take them, I don't know what I have, why do I need to take that for, I'm not taking them until you tell me why. When you tell me the name, I will take the pills like I'm supposed to."

Caregivers' deceptions and their implications. Because HIV is a highly stigmatized health condition, some caregivers attempted to conceal the HIV diagnosis from participants and other family members. This subterfuge usually required characterizing the youth or mother's condition as a less stigmatized illness. Although this action, as most participants indicated, was meant to protect them, in most cases it had the opposite effect: it increased anxiety and fear among study participants. The most frequent explanations parents/caregivers gave, as reported by participants, were that ART was vitamins "to make them healthier;" or that the medication was to treat asthma or a heart condition. Two study participants were told that their mothers had "cancer;” both saw their mother suffering and dying because of a supposed "cancer." A female participant wanted to die like her mother; another was scared and anxious because she concluded that she had "cancer" as well, since both were taking the same medication.

Fernanda, a 29- year old housewife and mother of two, shared her agony when confronting her ignorance about her diagnosis at the time that she watched her mother die:

So when my mom died, I was already taking pills... When they gave AZT [zidovudine] to me in pill form and I saw that it's the same pill that my mom would take, well, I started worrying. But no one told me that my mom had HIV; they told me she had cancer, so I thought I had cancer. And obviously I would 
look at my mom, I saw how much she suffered, and those are images that I will never forget. It was horrible.

Though they later realized that their caregivers' decision to mislead them was based on a desire to protect rather than to harm them, all agreed that it would have been better to have been told the truth about their HIV. When study participants finally learned the truth about their infection, some felt betrayed by their caregivers while others reported feeling "stupid." Alejandra, a 21-year old college student, shared her anger at her father's behavior:

Well, I felt angry at my dad, because, you know, so many years taking these medications. He never told me, he simply told me take these medications for your health.

And Isabel, a 22-year old mother of two, narrated:

When I found out that, yes, that I had it, I felt so stupid... well, because so many people knew it except me, everybody knew it, my family, everybody, everybody but me.

\section{The Evolving Meaning of Medication}

ART is a combination of several antiretroviral drugs used to suppress the replication of HIV and halt the progression of HIV related immunodeficiency (World Health Organization, 2014). ART and the regimens that precede ART have evolved significantly during the last 25 years. The numbers of pills needed for ART, regimens schedules, and reported adverse effects have all changed considerably. In this context, participants' narratives illustrated how the meaning they ascribed to medication gradually evolved, intersecting with critical developmental stages in their lives. The latter were 
clearly intertwined with their life course development, especially at the time in which they learned of their HIV diagnosis. For most, this occurred during their adolescence. Their growing maturity and concomitant awareness of their diagnosis facilitated greater medication adherence. According to participants' narratives, the process unfolded slowly. When they were children, ART meant "vitamins" or medication for another health condition; they were told that ART was something they needed to take to be (or stay) healthy. Later, after they learned their diagnosis, medication became something difficult to take, but essential to their lives. Most agreed that medication means "life," but also acknowledged that they have no choice: they must take medication for life if they want to be healthy.

Their responses reflected contradictory, ambivalent, and conflicting views regarding medication, as indicated below. For Isabel, medication means life, but she also acknowledged that she gets tired:

[Referring to ART] My life. That's my life. [BUT IT GETS TIRING] (laughs) Yes they tire me out, but it's true, it's true, I can't lie, those medications, that's where my heart lies, as people say. But yes, obviously, it's obvious that if I don't take the medications I will end up in a hospital and God knows what will happen. I could even die because it's the reality of life, that's what the condition is like.

Marina, a 23-year old college student, recognized that because of ART she is healthy. She noted:

But the medications, of course, they are my salvation at the moment; if it weren't for them I wouldn't be here, so well and so alive. 
Mauricio, a 19- year old single student, depersonalized the meaning of medication to him, but also acknowledged that it was good for him:

Well, the medications are a useful tool to maintain my health status the best it can possibly be.

\section{Understanding the Struggles and Challenges of ART}

Medication intake. For pHIV-I youth, taking medication is a daily reminder of their condition. Although participants understood the importance of ART, once they knew their HIV status, they also acknowledged that taking medication was not easy. Marina, one of the oldest participants in the study, recalled how her family coped with the problem that no pediatric antiretroviral formulation existed during her early childhood:

Like I told you, they would mash my medicine [pills] and put it in my [baby] bottle.

Others remembered that the only medication that was available during their childhood was zidovudine. Esteban, a 26-year old self-employed participant, had to visit the clinic monthly in order to receive intravenous medication. ${ }^{2}$ He shared his experience below:

I would get an IV and a transparent liquid. [BUT HOW OFTEN?] Monthly. [SO YOU WOULD HAVE TO COME...] monthly to get that, monthly all the time... After that I think they gave me some pills; they didn't give me many pills, and

\footnotetext{
${ }^{2}$ Most likely intravenous immunoglobulin (IVIG), which, before the introduction of combination ART, was one of few treatments that affected the course of pediatric HIV (National Institute of Child Health and Human Development Intravenous Immunoglobulin Study Group 1991).
} 
before the pills, sorry to interrupt, I got injections. They would give me injections whose name I can't remember, so I also went through that process.

Some participants also complained about the bad taste of the liquid medication. Marina commented:

...they would give me liquids. There was one that tasted bad, really bad and to take it, they would have to sit me down like this (simulates the siting), and my aunt was the one that would give it to me...'ok I'm going to give it to you' and we would always have a little cup of liquid chocolate because it tasted so bad. But they really had to make me take it.

“Side” (adverse) effects. Eight of the 20 participants expressed suffering from ART adverse effects at some point in their lives. For some, the effects included a terrible skin rash, which they characterized as “shingles”; for another, it was jaundice. Arturo’s comments regarding an adverse effect he experienced were as follows:

Well, I had shingles, because some of the medications gave me the shingles virus. The change of medication gave me a rash that I couldn't handle; I was covered with blisters. ${ }^{3}$

Another major adverse effect of antiretrovirals is lipodystrophy, a complex and severely disfiguring syndrome characterized by fat redistribution often associated with accumulation of fat in the abdomen and lower neck. It causes a humpback deformity; loss of fat in the cheeks, arms and thighs; and metabolic abnormalities (Carr, 2003). It is seen with a wide variety of ART regimens and appears to be due to mitochondrial

\footnotetext{
${ }^{3}$ This episode of shingles may have been an immune-reconstitution inflammatory syndrome related to recovery of immune function after ART initiation; shingles is caused by the reemergence of chickenpox [varicella zoster] virus along a nerve root where it was latent (Luwak \& Dill 2012).
} 
toxicity related to antiretrovirals, particularly nucleoside reverse transcriptase inhibitors. Lipodystrophy reportedly had the greatest impact, both physically and emotionally. Marina (a female respondent) recalled:

Well, of my medications' side effects, it has affected me the most [referring to lipodystrophy].

Isabel agreed, saying:

I think that of everything, everything, everything, the worse, the most difficult has been to accept [referring to lipodystrophy].

Four of the 12 women in the study reported that they suffered from lipodystrophy associated with one or more antiretrovirals. These four women were slow to understand what was happening to them or why their fat was not proportionally distributed in their bodies. Initially, they began disliking themselves because of their body shape, which they described as, "too skinny with a huge bust, or too skinny with a big belly.” They were not aware that the changes in their body shapes were related to their medications' adverse effects and assumed that that their deformities were genetic. As a result, they experienced low self-esteem and shame for years. It was not until they dared to ask their physician about their physical appearance that the physician disclosed that these body changes were a result of ART. In all cases the medication was changed; however, the effects were not reversed by the new medication alone.

Marina shared her experience with lipodystrophy:

I complained, but [it is] as an adult that you can notice it more obviously...I have this...big bust and my fat is in my stomach...my arms are skinny, my legs too. Well maybe you hadn't realized it - no- (both of us laugh) But there are people 
who say, 'your arms are really skinny' and one starts feeling insecure and my face, you can't tell, it was sucked in, sucked in, to the inside, all of it. And I complained, I said: "Look, why”? And that's when they told me 'look, you have been taking a medicine...that doesn't distribute the fat very well'. Then I complained and they said "we'll take you off it" they took me off it, I don't know, about 5 years ago.

All of the women suffering from lipodystrophy shared with the interviewer that they were bullied at school because of their unusual body shapes. Some managed the situation better than others. Two of the women, Fernanda and Isabel, left school because of the constant bullying; one in $8^{\text {th }}$ and the other in $10^{\text {th }}$ grade. When asked why they made that decision, both said that they could not handle the bullying and mocking in school anymore.

Fernanda narrated her experience while in school:

I don't remember much about school, but, um... it's like I tell you, the things, the memories I have, they're like bad memories. Because what I remember from school is that I started leaving school and I left it because they would make fun of me in school, because since I was little I have always been very skinny, so skinny that I looked like a twig and then I was very... busty and I didn't have anything back there and they would poke fun at me in school. And that would, I really do remember that that affected me a lot; I suffered a lot when the boys made fun of me because of that... Even when I was 25 years old I would be self-conscious and wouldn't want to wear certain clothes; I would dress in long skirts. Me wear a 
pair of jeans? I wouldn't dare, because I was ashamed and this stayed with me since I was a young girl.

Isabel also suffered at school:

Well, me being the way I am, physically, plus they always be saying things like, "You look like a man, a transvestite, whatever," things about the condition. With the boys treating me like that, little by little they lowered my self-esteem.

The other two participants who suffered from lipodystrophy found an alternative approach. Both of them complained about being "too skinny and having sunken cheeks.” The UPR Pediatric HIV/AIDS Research Program, linked them with a physician who treats patients who suffer from lipodystrophy by injecting "fat" or synthetic material in the areas where fat had been lost (Carr, 2003). After the procedure, both reported that, although painful, they felt "happier with their appearance and in love with their new cheeks.”

Marina observed about the experience:

And he specializes in that, it's in [municipality in Puerto Rico] and they gave me the option, and when we filled all the paperwork the government covered it, and they did it about a month ago. [] [ARE YOU HAPPY WITH YOUR CHEEKS?] [both laugh]- Yeah [TOUCHES HER CHEEKS] I am... I never had them, never because since I was... I think that, he asked for pictures of what I looked like as a baby, and in my first year I was a ball of fat and you see by my second birthday all the fat had left my face. You know, from the time I was two years old to now, I didn't have cheeks. 
Emma, a 20-year old college student, described how she felt before and after having her cheeks filled and how her self-esteem improved afterwards:

Yes, well I'm very skinny, and it sucked the fat from my face, I had to get filler. [IN YOUR CHEEKS?] Yes. I have filled... these cheeks have been filled (both laugh). []. [AND HOW DO YOU FEEL, BEFORE AND AFTER?] Oh super, because before, I felt, ugly... I looked at myself and did not like it. Now I see myself in the mirror and I like what I see; my self-esteem rose. It was a lot, it was really, it was almost down to the bone, that's why it hurt so much. When they went in, they had to fill in a lot. [IMAGINE] Yes, and so that, the pills did that to me. He made a pocket of fat here, and distributed the fat in a bad place. Before I was almost a D bra size and I was really skinny, skinnier than now. Because of the pills, so they took me off them, and [the fat] went down little by little.

Challenges to adherence. Having had to take medication from a very early age, pHIV-I youth shared some of their ART adherence strategies. Like many other things in their lives, strategies for adherence also evolved through their various life stages. When they were very young, family members or caregivers were responsible for the youths' adherence to medication. Parents and caregivers reminded them to take their medication or actually gave them the medication. Among study participants, there was an explicit connection in their narratives between assuming responsibility for ART intake early in their lives and adherence to treatment in adulthood. Some participants attributed their failure to assume the responsibility for medication intake in early adulthood to their parents or caregivers not training them and expressed greater difficulty with adherence. As Isabel expressed it: 
What happened was that my grandmother used to give them to me herself. I was grown already... 12, 13, 14 years old... she, poor lady, would come with a cup of milk to my bed and she would give them to me. What happened is that she didn't teach me to be responsible from an early age with my own pills, me being the one that should've gotten up. When all of a sudden I had to become independent, live alone, and I got an apartment, got pregnant, up to the present, I've been very irresponsible with my pills. []Because I can't get used to it and I've been living on my own for two years now, two years and six months and I can't get used to it; sometimes even a week goes by [WITHOUT TAKING THEM].

Other challenges to adherence experienced by study participants were fatigue and indifference with adherence to their medication regimen. While they understood the importance of ART in their lives very well, they also acknowledged that sometimes ART interfered with their daily activities and social lives. Often, what made study participants feel different was not necessarily having HIV, but rather having to follow a daily medication regimen. Some, like Isabel, even expressed a desire to be "normal" and not take medication anymore:

[talking about ART] ... you get very tired, you get very tired of the same. There comes a point when you want to feel normal, to not have to be taking medication like other people. It's really tiring, man, you get really tired (Isabel, 22 years old).

Alonso indicated how his busy schedule interfered once with his medication intake: Yes there was, a time, a time when I didn't take them, a time when I was younger. I didn't take them, I didn't take them for a while. But later I started taking them 
again. [WHY DIDN'T YOU TAKE THEM?] Well, because at first...when I started at university, a lot of times it was because I was busy and in a hurry. Sometimes I left in the morning I didn't remember and when I remembered I was already on my way; well, I'll take it at night or I'll take it now or take it later; and by the time I realized it I hadn't taken them and I was like that for a while.

Alejandra observed that she is responsible with her medication, but admitted that she forgets to take them when going out for fun:

Yes, like I'm supposed to. But sometimes every once in a while, you know if something happens at night, well, you know, I forget to take it then and if there's alcohol involved well, I'm more likely [to forget]...

Similarly to Alejandra, Arturo, a 22-year old father of two, said that he was very responsible with his therapy but acknowledged that sometimes he forgets to take the medication:

It's somewhat of a nuisance to be taking so many things. When one goes out to have fun, one is not thinking about medication. I am pretty rigorous with that, but that I forget, obviously I forget.

\section{Meaning Construction for Adherence Strategies}

Establishing a daily routine. Study participants talked about adherence. Those describing themselves as adherent expressed that at this point in their lives, medication intake was a normal process, completely incorporated into their daily routines. Incorporating medication intake into their regular activities seemed to enhance and support medication adherence for these participants. Alejandra shared her experience with her medication intake: 
It's routine: I wake up and I immediately get a water bottle from the fridge and I take out the pills I have to take and that's it. And then at night, at about 9 or 10pm, I take the other ones.

Marina’s narrative concurred with Alejandra’s opinion:

Force of habit (she laughs). I have been taking medicine all my life... and also I don't think about it; you know, I don't say I need this to survive; no it's automatic already.

Social support. Some study participants said that their family members or significant others reminded them to take their medication. Study participants saw this as an act of love rather than an undesirable prompting or interference. They recognized the importance of being adherent and really appreciated that someone besides themselves cared about them and helped them with their medication intake. In some cases, this person was a parent; in others, a partner; and, in some cases, an offspring. Emma told of her experience with her mom and boyfriend:

My mom (both of us laugh) ... at night I already know before going to bed. Well sometimes... I've wanted to, they've [healthcare providers] dealt a lot with my mom. The doctor herself [has said] "look you have to let her remember" but, that's how she is... she puts hers next to mine. When I wake up she puts them next to my breakfast. Yes, (she laugh) sometimes at night, my boyfriend reminds me, he says “hey, did you take the pills?” like that.

Fernanda found her support in her daughter:

...I told her,[daughter's name] help me, because, honestly, sometimes I get up to take care of the baby and sometimes it gets to be 11 o'clock in the morning and I 
say, “Oh God, I haven't taken the pills.” And, honestly, by that time I just don't take them.

Adherence Promoting Devices. The mechanical devices used by study participants ranged from commonly available instruments to more sophisticated technology including alarms. Some said that a pillbox helped them organize their weekly medication and made their medication intake an easy process. Fernanda and Carla were two who used pillboxes to organize their medication; they explained:

I have the pill box on top of the table; my daughter has 18 alarms that say “remember mom's medicine" (Fernanda, 29 years old). ...like I've told you, I have my pill organizer, one for the morning and one for the evening (Carla, 23 years old).

Others relied on the alarm in their cellular phones and noted that it was a good reminder of ART intake. Miranda, a 19- year old single mother, said that she even writes a reminder on her hand when her cell phone is not available.

Well, I put it on my cellphone, in the calendar and it reminds me when it's time. If I don't have the cellphone at hand ... I write it on my hand or somewhere to help me remember.

\section{Discussion}

The life course of an individual consists of multiple transitions (changes in roles and statuses) and social trajectories (longer-term patterns of stability or change). These transitions and trajectories are shaped by the historical context in which they take place (Elder, 1998). Not surprisingly, the phenomenological approach employed in this study, captured the dynamic and interconnected process that emerged between participants’ 
diverse trajectories and their respective interactions with ART therapy. The latter shaped and in turn was shaped by life events and turning points in their lives.

The history of the AIDS epidemic and the populations associated with the disease since its earlier years (homosexuals, injection drug users, and commercial sex workers), have contributed to the stigmatization of AIDS patients and their rejection by society. Study participants were born between 1983 and 1994, during the very early years of the epidemic. In an effort to avoid their suffering as children, their HIV-infection status was concealed from them. The reasoning behind withholding disclosure was partly based on the then mortality rates which were very high at that time; patients were expected to die before it was necessary or appropriate to explain their illness to them. Study participants were also part of a historical juncture in which most were born before the use of zidovudine (AZT) to prevent mother-to-child transmission. However, they benefited from the introduction of ART that allowed them to live longer and healthier lives. According to participants, their daily reliance on ART triggered their discovery of the truth about their HIV infection. Most study participants had been taking some medication since their infancy; however, the real reason for medication intake was withheld from them as children. Although pHIV-I youth in this study expressed a desire to know what was going on with their health, they also revealed that the truth about their HIV-status was not easy to learn. Several study participants reported having parents and caregivers who lied about their health status. For both family members and study participants, the revelation of the truth about their diagnosis became a complex situation; the former had to face their own fears in order to be honest with the infected children. 
Among Puerto Ricans, social interaction is vital. Family and friends are major sources of support (Varas-Díaz, Serrano-García, \& Toro-Alfonso, 2005). The decision by parents and caregivers to conceal participants' HIV-infection from them and to others is in a way understandable. Research conducted on HIV "has shown that Puerto Ricans assigned great importance to family relations” (Díaz, 1998 as cited in Varas-Díaz et al., 2005, p.181). Besides their attempt to avoid their loved ones from suffering because of the stigma attached to it, it is also very likely that caregivers wanted to protect their own primary sources of support and their social interactions. Revealing participants' HIV infection to them or to others placed them in a vulnerable position. As noted by VarasDíaz et al. (2005), close relationships with family and friends can be double-edged, a source of support or a source of stigma (Varas-Díaz el at., 2005).

As participants frequently indicated, some used ART as a way to force parents or caregivers to tell them the truth about their status. These participants told the researcher that knowing they were HIV-positive gave them some relief because they finally knew the name and nature of their illness. Others acknowledged feeling betrayed by their caregivers when they discovered the truth. In their meaning construction of both their health condition and their dependence on ART, they indicated that when a certain level of maturity was reached, then parents and caregivers were morally obligated to share the truth about their condition. In retrospect when recreating the moment of disclosure during the interview, they felt anger and a sense of frustration that this moment of truth had to be forced or negotiated with their parents or caregivers. The experience of discovering a "secret" that everyone knew except them, the most affected parties, was one of anger and betrayal. As their narratives suggested, these feelings prevailed even 
when there was some understanding of the good intentions behind the attempt to "protect" the child from the truth.

Perinatally HIV-infected youth in the United Kingdom reported similar experiences of feeling "stupid" and "betrayed” by their caregivers (Dorrell \& Katz, 2013). Because of the secrecy around them and their health status, some study participants in Puerto Rico used clues, information, and their lived experiences to reach a conclusion about their health. Two study participants believed they had cancer like their mothers, and concluded they were going to die of cancer as their mothers did. A similar situation emerged in a study conducted in the United Kingdom by Dorrell and Katz (2013) among a sample of pHIV-I. Caregivers did not know that they had caused study participants unnecessary stress and anxiety. All study participants agreed that it is better to know, and that knowledge was important in order to assume responsibility for their medication and medical treatment. Most indicated that learning the truth about their diagnosis marked a turning point in their lives. It was an event that changed their life course trajectory forever. As noted by one participant, knowledge of their condition marked a transition "from being a healthy individual to an individual with a chronic health condition.” The latter reinforces the interconnectedness between life course transitions and the medication intake process.

Similarly, Blasini et al. (2004) found that participants self-reported that knowing their diagnosis helped them to develop better adherence to ART. As in that study, participants in this study said that, once they knew their HIV-infection, they understood the importance of ART intake and adhering to a regimen. They also reported that they began to care more about their health once they learned their HIV status. They now see 
ART as their lifeline and what keeps them healthy, and they very much prefer this knowledge to the previous false references to their condition as asthma, heart medication or vitamins. However, it is important to note that in the Blasini et al. (2004) study, one participant (of 40) continued depressed months after finding out his status in the disclosure study, and insisted that he would have preferred never to have known. Even when study participants understood the importance of ART, they also realized and acknowledged the difficulties inherent to daily medication intake. Their narratives indicated they were as active as any youth. It was precisely, the normality of their lives, they reported, that interfered with ART adherence: having a busy life, busy schedules, friends, and a social life. Among the tools they reported to help with ART adherence were incorporating their ART intake into their daily routine, using a pillbox and cell phone alarms, and reminders by family and loved ones. These strategies suggest that "routinizing” medication intake in the context of predictable life events (Wagner \& Ryan, 2004) (in contrast to "mindfulness" of what the medications treat) may be a more acceptable and effective for promoting ART adherence in some youth without consciously dwelling on the painful topic of HIV.

The lives of pHIV-I youth have been touched by a variety of major life events or “abrupt changes that may produce serious and long-lasting effects” (Hutchison, 2010, p.12) such as losing a parent, becoming orphaned, being cared for by family members, difficulties experiencing when reaching puberty, and the dilemma of disclosing or not their diagnosis. Experiencing the side effects of ART was an added burden to their life trajectories and one that affected their life course, as most chronic illnesses do. 
Some participants experienced much worse adverse effects than others. Of the twenty who participated in the study, eight reported suffering from serious adverse effects ranging from mild, self-limited or manageable to disfiguring beyond the control of the physician and patient, and permanent. The latter exerted a major impact on the lives of the youth. Interestingly, lipodystrophy was reported as the worst side effect, even more difficult than having HIV. Participants with lipodystrophy suffered the rejection and aggression of their classmates because of their appearance, more than HIV-related discrimination.

Goffman (1963) defined stigma as an attribute that is deeply discrediting. This attribute makes a person "different from others" and "of a less desirable kind" (Goffman, 1963, p. 3). Goffman identified three types of stigma: (1) abomination of the body, which refers to physical deformities; (2) blemishes of the individual is stigma associated to the character of the individual; and (3) tribal stigma related to race, nation, and religion (Goffman, 1963). At present HIV patients continue to suffer rejection, discrimination, and stigmatization. Lipodystrophy illustrates what Goffman (1963) called abomination of the body. For the study participants who suffered from lipodystrophy, their body shape represented a visual manifestation of having HIV. In some cases, participants took the drastic decision to drop out of school to avoid the rejection and aggression of classmates who mocked their looks and were hostile. The decision to withdraw, as indicated by the above examples of dropping out of school, ultimately represented an additional source of social isolation. Social isolation is an action that a stigmatized individual takes to avoid questioning, aggression or people ridiculing or tormenting them because of their appearance (Varas-Díaz, Serrano-García, \& Toro-Alfonso, 2004). This 
situation further illustrates how an ART adverse effect transcended the individual's condition and had an impact on her social life as well.

For years, none of the participants suffering from lipodystrophy knew that their body deformity was related to ART. They suffered in silence, in some cases for a considerable amount of time, and experienced low self-esteem resulting from their appearance. It was not until they dared to ask that they were told that their deformities were due to ART. For the researchers, it was baffling to learn that otherwise sensitive physicians failed to explain to their young patients the reasons behind their disfigurement. Participants, who went through medical procedure to treat lipodystrophy effects on their bodies, expressed feeling "great" after the procedure and with higher selfesteem. This provides a clear example of how understanding the reasons underlying the condition led these two young women to pursue a course of action that resulted in a positive "life event" that altered their self-image and transformed their daily lives.

\section{Conclusion and Implications}

According to Elder (1998) an individual's life course is full of transitions and trajectories. For pHIV-I youth, being HIV-positive shaped or configured a distinct life trajectory which was indelibly affected by this condition. Disclosure and acceptance of their HIV infection status framed a major transition in their life trajectories and especially in strengthened their adherence to ART. However, their lives did not come to a halt because they experienced this major turning point; on the contrary, their lives continued, albeit with the additional burden of their diagnosis, but with increased awareness of the role of ART for their health and survival. 
This is a population that has continually faced challenge after challenge, including parental loss and orphaning, being raised by other family members, discovering the truth about their diagnosis, dealing with ART and its adverse effects and eventually assuming the responsibilities of work, school and family. As they repeatedly indicated, they must continually overcome these challenges in order to lead as normal a life as possible and thrive despite their condition.

All participants agreed on the importance of being treated as young individuals capable of understanding and dealing with learning of their HIV status. Specifically, participants believed that this was especially relevant to their daily interactions with ART which includes adherence and compliance. Participants strongly emphasized that paternalism and overprotection, even when well-intentioned, were ineffective in protecting them from rejection and discrimination. In general, they agreed that in the end, lies about their condition were more harmful than beneficial, as in the case of ART intake. Similarly, all pointed out that family members, caregivers and health professionals need to listen and respect their wishes in matters related to their health outcomes. Moreover, proactive explanations of emerging adverse effects, particularly disfiguring effects that were not self-limiting, would likely had been effective in having the patients feel "normal" and led them to access effective treatment in a timely fashion.

Participants emphasized the importance of engaging patients and caregivers as equal partners with health care providers in making treatment decisions and ultimately deciding what was best for them. They insisted on the importance of having adult health care services to help them to better understand their diagnosis, particularly in increasing their overall understanding of their medication regimen and adherence, responding to 
stigmatizing experiences, enhancing their self-esteem and body image, and furthering their goals to live a healthy life with HIV. Additionally, their narratives indicated that the needs of caregivers and family members need to be repeatedly assessed, since, capacity building and support are critical to caregivers in their role as effective partners in the transition of the pHIV-I person from a dependent childhood to an independent and successful adulthood. This process, as respondents repeatedly noted, begins with disclosure of the HIV infection status to the child (Blasini et al., 2004) and is intrinsically important for ART adherence and compliance. 


\section{References}

Arrivillaga, M., Martucci, V., Hoyos, P., \& Arango, A. (2013). Adherence among children and young people living with HIV/AIDS: A systematic review of medication and comprehensive interventions. Vulnerable Children and Youth Studies, 8(4), 321-337. Retrieved from http://dx.doi.org/10.1080/17450128.2013.764031

Blake, B., Robley, L., \& Taylor, G. (2012, November-December). A lion in the room: Youth living with HIV. Pediatric Nursing, 38(6), 311-318.

Blasini, I., Chantry, C., Cruz, C., Otriz, L., Salabarria, I., Scalley, N., . . . Diaz, C. (2004). Disclosure model for pediatric patients living with HIV in Puerto Rico: Design, implementation, and evaluation. Developmental and Behavioral Pediatrics, 25, 181-189.

Brown, L., \& Lourie, K. J. (2000). Children and adolescents living with HIV and AIDS: A review. Journal of Child Psychology and Psychiatric, 41(1), 81-96.

Carr A. (2003). HIV lipodystrophy: Risk factors, pathogenesis, diagnosis and management. Aids, 17, S141-S148.

Creswell, J. W. (2007). Qualitative inquiry \& research design: Choosing among five approaches (2nd ed.). Thousand Oak, California: Sage Publication, Inc.

Dorrell, J., \& Katz, J. (2013). "I knew I had something bad because no-one spoke about it" - disclosure discovery: Experiences of young people with perinatally acquired HIV in the UK. Vulnerable Children and Youth Studies, 8(4), 353-361. Retrieved January 2014, from http://dx.doi.org./10.1080/17450128.2013.774453

Elder, G. H. (1998, Feb). The life course as developmental theory. Child Development, 69(1), 1-12. Retrieved April 2014, from http://www.jstor.org/stable/1132065.

Fair, C., \& Albright, J. (2012). “Don't tell him you have HIV unless he's 'The one’”: Romantic relationships among adolescents and young adults with perinatal HIV infection. AIDS Patient Care and STDs, 26(12), 746-754.

Goffman, E. (1963). Stigma: Notes on the management of spoiled identity. New York, NY: Simon \& Schuster, Inc.

Grondin, J. (1994). Introduction to Philosophical Hermeneutics. Yale University Press. New Haven, Connecticut.

Hazra, R., Siberry, G. K., \& Mofenson, L. M. (2010). Growing up with HIV: Children, adolescents, and young adults with perinatally acquired HIV infection. The Annual Review of Medicine, 61, 169-185. 
Hogwood, J., Campbell, T., \& Butler, S. (2012). I wish I could tell you but I can't: Adolescents with perinatally acquired HIV and their dilemmas around selfdisclosure. Clinical Child Psychology and Psychiatry, 0(0), 1-17.

Hutchison, E. D. (2010). A life course perspective. In E. D. Hutchison, Dimensions of human behavior: The changing life course (pp. 1-38). Thousand Oaks , California: SAGE Publications.

Koenig, L., Nesheim, S., \& Abramowitz, S. (2011). Adolescents with perinatally acquired HIV: emerging behavioral and health needs for long-term survivors. Current Opinion in Obstetrics and Gynecology, 23, 321-327.

Larkin, M., Watts, S., \& Clifton, E. (2006). Giving voice and making sense in interpretative phenomenological analysis. Qualitative research in psychology, 3(2), 102-120.

Leonard, L., \& Ellen, J. (2008). "The story of my life": AIDS and 'autobiographical Occasions'. Qualitative Sociology, 31, 37-56.

Lester, S. (1999). An introduction to phenomenological research. Stan Lester Developments, 1-4. Retrieved on March 2013, from: http://www.sld.demon.co.uk/resmethy.pdf accessed

Michaud, P., Suris, J., Thomas, R., Gnehm, H., Cheseaux, J., \& MoCHIV. (2010). Coping with an HIV infection. Swiss Medical Weekly, 140(17-18), 247-253

Nicholas, S. W., \& Abrams, E. J. (2002). Boarder babies with AIDS in Harlem: Lessons in applied public health. American Journal of Public Health, 92(2), 163-165.

Patton, M. Q. (1990). Qualitative evaluation and research methods. Thousand Oaks, CA: Sage Publications, Inc.

Persson, A., \& Newman, C. (2012). 'When HIV-positive children grow up: A critical analysis of the transition literature in developed countries'. Qualitative Health Research, 22(5), 656 - 667. Retrieved from http://dx.doi.org/10.1177/1049732311431445

Rennie, D. L. (2007). Methodical hermeneutics and humanistic psychology. The Humanistic Psychologist, 35(1), 1-14.

Sherman, B., Bonanno, G., Wiener, L., \& Battles, H. (2000). When children tell their friends they have AIDS: Possible consequences for psychological well-being and disease progression. Psychosomatic Medicine, 62, 238-247.

Smith, J., Flowers, P., \& Larkin, M. (2009). Interpretative Phenomenological Analysis: Theory, Method and Research. Thousand Oaks, California: SAGE, Inc. 
Sohn, A. H., \& Hazra, R. (2013). The changing epidemiology of the global paedriatric HIV epidemic: Keeping track of perinatally HIV-infected adolescents. Journal of the International AIDS Society, 16(1)

UNAIDS. (2011). Countdown to zero: Global plan towards the elimination of new HIV infections among children by 2015 and keeping their mothers alive, 2011-2015. Retrieve from:

http://www.unaids.org/en/media/unaids/contentassets/documents/unaidspublicatio n/2011/20110609_jc2137_global-plan-elimination-hiv-children_en.pdf

UNAIDS. (2013). Global Report: UNAIDS report on the global AIDS epidemic 2013. http://www.unaids.org/en/media/unaids/contentassets/documents/epidemiology/2 013/gr2013/UNAIDS_Global_Report_2013_en.pdf.

Varas-Díaz, N., Serrano-García, I., \& Toro-Alfonso, J. (2004). Estigma y diferencia social: VIH/SIDA en Puerto Rico. Ediciones Huracanes.

Varas-Díaz, N., Serrano-García, I., \& Toro-Alfonso, J. (2005, February). AIDS-related stigma and social interaction: Puerto Ricans living with HIV/AIDS. Qualitative Health Research, 15(2), 169-187. doi:10.1177/1049732304272059

Vijayan, T., Benin, A. L., Wagner, K., Romano, S., \& Andiman, W. A. (2009). We never thought this would happen: Transitioning care of adolescents with perinatally. AIDS Care, 21(10), 1222-1229. doi:10.1080/09540120902730054

Wagner, G.J. \& Ryan, G.W. (2004) Relationship between routinization of daily behaviors and medication adherence in HIV-positive drug users. AIDS Patient Care STDs,18 (7), 385-93

WHO - World Health Organization (2014) Use of antiretrovirals for treatment and prevention of HIV infection [Online HIV treatment information]. Retrieved from http://www.who.int/hiv/topics/treatment/en/

Willis, W. J., \& Jost, M. (2007). Foundations of qualitative research; Interpretive and critical approaches. London: Sage. Page 106 


\section{Appendix A}

\section{Interview Guide}

\section{$\underline{\text { Personal Life }}$}

- How would you describe yourself?

o Happy, nervous, positive, negative, etc.

- What do you like to do in your leisure time?

- Do you have any goals you want to achieve in the future?

- What does “disease” mean to you?

- What does "HIV" mean to you?

- When did you find out about your diagnosis?

o How?

o Who told you?

o What did it mean to you?

- How would you describe your life before and after your diagnosis?

- How do you cope with your diagnosis?

- Have you considered becoming a parent?

- If she/he is, what has the experience been like?

- If she/he isn't what are your thoughts about it?

\section{$\underline{\text { Social Aspects }}$}

- What does "family" mean to you?

- Who have been the most meaningful people for you?

- Tell me more about your parents, who are or were they?

- How do you feel about your parents or what do you think about them?

- In your opinion, how does your family deal with HIV?

- Tell me about your experience at school, university or work environment?

- What do you consider most important before disclosing your diagnosis to others?

- Do your siblings or other family members know about your diagnosis?

- What do you consider are the pros and cons of disclosing your diagnosis?

- What does "friendship" mean to you? 
- What are your thoughts about intimacy in a relationship?

- Do you disclose your HIV status with intimate partners?

- Does your diagnosis have implications in your personal relationships? Positive? Negative? Would you give me an example?

Medical Aspects

- Tell me about your experiences with your health care providers (physicians, nurses, pharmacists, emergency room personnel, etc.)

- How long have you been taking medications?

- What does “medication” mean to you?

- What factors facilitate (or not) taking your medications?

- What additional services would you like to receive?

- How do you feel about your transition to adult care?

o How do you envision your adult care?

- What do you think about PREP for prevention? 


\section{Appendix B}

\section{Spanish quotes for the manuscript:}

\section{A Tough Pill to Swallow: The Meaning of ART for Puerto Rican Perinatally HIV-}

\section{Infected Youth}

- Eh, yo empecé como que a dudar, a eso de 10 a 12 años, porque comencé a preguntar, qué pastilla me estoy tomando?... yo dije en mi mente 'yo tengo algo', debo de tener algo (Mauro, 21 años).

- Viste cuando uno va creciendo pues uno va viendo la diferencia de que uno en medicamento otros niños no... (Alonso, 20 años).

- No, no me decía, ella [su mamá] me obligaba, me regañaba y todo y yo 'no me las voy a tomar, yo no sé lo que yo tengo, para que yo necesito tomarme esto, hasta que tú no me digas no pienso tomármelas'. Cuando ustedes me den el nombre, yo me bebo las pastillas como se supone que sea (Eugenio, 19 años).

- Entonces cuando mami muere que ya yo sé beber... Cuando me dan AZT en pastillas que yo veo que es la misma pastilla que mi mamá tomaba, pues empecé a preocuparme, pero a mí no me dijeron que mi mamá tenía VIH, me dijeron que tenía Cáncer, y yo creía que tenía Cáncer. Y obviamente veía a mi mamá, la vi como sufrió, que eso son imágenes que eso a mí no se me olvida, fue horrible (Fernanda, 29 años).

- "Pues me sentí enojada con mi papá, porque tú sabes tantos años en tomarme estos medicamentos. Él nunca me explicó así, el simplemente me dijo tomate estas medicinas para tu salud (Alejandra, 21 años). 
- Y cuando, eso fue otra que cuando yo me enteré que sí que yo la tenía yo me sentí tan, estúpida, pues porque mucha gente lo sabía menos yo, todo el mundo los sabia, mi familia, todo el mundo, todo el mundo menos yo (Isabel, 22 años).

- Mi vida. Ahí está mi vida. [PERO TE CANSAN] (risas) Me cansan sí, pero es verdad, es la verdad no puedo mentir, esos medicamentos, ahí está mi corazón como quien dice, porque si yo, obviamente, es obvio que si yo no me sigo tomando los medicamentos voy a decaer en un hospital y sabe Dios lo que pase, hasta me puedo morir porque es la realidad de la vida, así es la condición (Isabel, 22 años).

- Pero los medicamentos, claro que son mi salvación ahora mismo, si no fueran por ellos no estuviese aquí tan bien y tan viva (Marina, 23 años).

- Bueno pues los medicamentos, es una herramienta útil para mantener mi estado de salud, lo mejor posible (Mauricio, 19 años).

- A mi machacaban lo medicamentos de adultos y me lo ponían en el bibi para poder... (Marina, 23 años).

- Yo recibía suero y un liquidito transparente. [PERO CADA CUANTO TIEMPO] Mensual. [O SEA QUE TU TENIAS QUE VENIR] mensual a recibir eso, mensual todo el tiempo.... Después de ahí yo creo que me dieron unas pastillas, no me dieron bastantes pastillas, y antes de las pastillas, perdóname que te interrumpa, me inyectaba, me ponían inyecciones que no me acuerdo como se llama, que también pasé por ese procedimiento (Esteban, 26 años).

- [] me daban líquido en lo que, había una que sabía mala, malísima y para yo tomármela, me tenían que sentar así, y mi tía era la que me la daba, mi Tia 'okay, te 
la voy a dar' y siempre teníamos un vasito de líquido de chocolate porque sabía tan mala, pero ahí si tenían que obligarme a tomármela [] (Marina, 23 años).

- Pues me dio culebrilla, porque unos medicamentos me sacaron pues el virus de la culebrilla. En el cambio de medicamentos me dio un rash que no podía ni con mi vida, me llené todo de ampollas (Arturo, 22 años).

- Pues eso fue lo más que me afecto, de efectos secundarios de mis medicamentos [refiriéndose a la lipodistrofia] (Marina, 23 años).

- Este, yo digo que de todo, todo, todo lo peor, lo más difícil que se me ha hecho asimilar [refiriéndose a la lipodistrofia] (Isabel, 22 años).

- Yo me quejé, ya pero ya cuando grande que se nota más obviamente, pues yo tengo esto bien, el busto grande y mi grasa se concentra en el estómago si te das cuenta, mis brazos son flaquitos, mis piernas también. Bueno a lo mejor no te habías dado cuenta -[NO]- (carcajadas de ambas) Pero hay gente que me dice, 'tú tienes los brazos bien flaquitos' y a uno le empieza a dar inseguridad y mi cara, que no se nota, era chupa, chupa, para adentro entera. Y yo me quejé, yo le dije mira por qué? Y entonces ahí fue que me dijeron 'mira tú llevas casi tomando una medicina que lo que hace es que no te distribuye bien, no sabe cómo distribuir la grasa bien'. Entonces yo me quejé y me dijeron 'vamos a quitártela' me la quitaron que se yo hace como 5 años atrás (Marina, 23 años).

- De la escuela no me acuerdo mucho, pero, este...es como te digo, las cosas, los recuerdos que tengo, son como recuerdos malos, porque yo lo que me acuerdo de la escuela era que empecé a dejar la escuela y la dejé porque me vacilaban en la escuela, porque yo desde chiquita siempre fui bien fllllllaaaacaaa, pero flaca que 
parecía un palillo entonces era bien....tetona y no tenía nada de atrás y me vacilaban en la escuela y eso a mí me, de verdad que yo me acuerdo que eso me afectó un montón, yo sufría un montón cuando los nenes me vacilaban por eso... todavía a los 25 años yo tenía complejo y yo no me atrevía ponerme una ropa, yo me vestía con faldas largas, yo ponerme un Mahón, yo no me atrevía, porque tenía esa vergüenza, me quedé con eso desde chamaquita (Fernanda, 29 años).

- Pues al yo ser como soy, físicamente, más ellos siempre me decían palabras como, que si pareces un macho, que si travesti, que si whatever, y son cosas que si lo de la condición, los muchachos tratándome de esa manera, poco a poco me fueron bajando la autoestima (Isabel, 22 años).

- Y él se especializa en eso, es en [municipio de Puerto Rico] y me dieron la opción, y cuando hicimos todos los papeleos el gobierno nos lo cubrió, y me los hicieron hace como un mes. [Y ESTAS CONTENTA CON TUS CACHETES?]- Siii [SE TOCA LOS CACHETES] yo estoy...nunca los tuve, nunca porque ya...cuando yo cumplí dos a mi cara se le había ido toda la grasa. Tus sabes, que eso fue desde los dos años hasta ahora yo no tenía cachetes... (Marina, 23 años).

- Sí, pues que yo soy muy flaquita, y a mí me chupó la grasa de la cara, yo me tuve que poner relleno. [EN LOS CACHETES?] Sí. Tengo rell...estos cachetitos son rellenos (carcajadas de ambas) [] [Y COMO TE SIENTES, ANTES Y DESPUES?] Ay súper, porque antes me sentía, fea...antes me veía y no me gustaba. Ahora me miro en el espejo y sí me gusta, me subió el autoestima. Era mucho, estaba bien, estaba llegando casi al hueso, por eso fue que me dolió tanto, cuando entraban, tenía que despegar mucho. [IMAGINATE] Si, y pues eso, me hizo las mismas pastillas. Me 
hizo un chichón aquí de grasa, eso es que me distribuyo la grasa en mal lugar. Antes yo era, casi D de brassiere y yo era bien flaca, más flaca que ahora. Por las mismas patillas, entonces me las quitaron, entonces se fueron bajando poco a poco (Emma, 20 años).

- Lo que pasa es que mi abuelita, me acostumbro a dármelas ella, siendo grande ya de 12, 13, 14 años ella iba, bendito, con un vasito de leche a la cama, me las llevaba, que pasa no me enseñó a ser yo responsable desde chiquita con mis pastillas yo siendo yo la que tuviera que levantarme. Cuando de la nada yo tuve que independizarme, vivir sola, me dieron el apartamento, caí preña, hasta el día de hoy, yo he sido tan irresponsable con mis pastillas... [] Porque no me acostumbro y llevo ya dos años viviendo sola, dos años y seis meses y no me acostumbro, a veces pasas hasta una semana [sin tomárselas](Isabel, 22 años).

- [TALKING ABOUT ART] y es que te aborreces, te aborrece de lo mismo, llega un punto que quieres sentirte normal, como los demás no tener que estar bebiendo esos medicamentos y cansa en verdad, acho en verdad cansa (Isabel, 22 años).

- ...un tiempo sí no me los tomé... Pero que después me los volví a tomar. [PORQUE NO TE LOS TOMASTE?] Na' porque primero empezó como que fue, cuando empecé la universidad que muchas veces era por el ajetreo. A veces salía por la mañana no me acordaba y cuando me acordaba ya iba en camino, pues me lo tomo por la noche o me lo tomo esto, me lo tomo aquello y cuando venía a ver pues no me los tomaba y estaba así tiempo (Alonso, 20 años). 
- [] Si, como Dios manda, a veces uunna que otra vez, tu sabes si salgo por la noche, pues tu sabes se me olvida en esa ocasión y si hay alcohol envuelto pues menos todavía [] (Alejandra, 21 años).

- Poco pesado estar tomando tantas cosas, cuando uno sale a divertirse no está pensando en medicamentos. Soy bastante riguroso con eso, pero de que se me olvidan, obviamente se me olvidan (Arturo, 22 años).

- Es algo ya rutinario, me levanto enseguida saco una botella de agua de la nevera y saco las pastillas que me tengo que me tomar y ya. Y después por la noche, ya como a eso de las 9 o 10pm me tomo las otras (Alejandra, 21 años).

- Costumbre (risas de ella) yo llevo toda mi vida tomando medicina y ya... y también no lo pienso, tú sabes no digo, esto es para yo sobrevivir no es ya automático (Marina, 23 años).

- ....mamí (risa de ambas) este por la noche ya yo sé antes de acostarme pues a veces... He querido, han bregado mucho con mi Mai, la misma doctora, mira déjala a ella que se recuerde, pero na' esa es ella...las pone al lado de la mía. Cuando me levanto me la pone ahí con mi desayuno. Si, (risa de ellas) a veces por la misma noche, el mismo novio mío me lo recuerda, me dice mira ya te tomaste las pastillas, y así (Emma, 20 años).

- ...yo le dije a ella, [nombre de su hija] ayúdame, porque de verdad sinceramente, a veces yo me levanto a atender el bebe y a veces dan las 11 de las mañana y digo 'Dios mio, no me bebí las pastillas' y sinceramente a esa hora ya yo no me las tomo (Fernanda, 29 años). 
- Tengo la cajita de las pastillas encima de la mesa, mi hija tiene 18 alarmas, que dicen 'acuérdese medicina de mami' (Fernanda, 29 años).

- [] y como te digo tengo mi pastillero, el de por la mañana y el de por la noche (Carla, 23 años).

- Pues lo pongo en el celular, en la agenda y me lo va acordando cuando me tocan. O si no, pues si no tengo el celular en la mano, pues o lo escribo en la mano o en algún lado que me acuerde (Miranda, 19 años). 


\section{SECOND MANUSCRIPT}

\section{Reconstructing the Truth: The Life Experiences of Puerto Rican Perinatally HIV-}

\section{Infected Youth with Disclosure}

Georgina Silva-Suárez, ${ }_{1}$ Elena Bastida, ${ }_{1}$ Consuelo Beck-Sagué, ${ }_{1}$ Silvia E. Rabionet, 2,3 and Irma Febo, 3

${ }_{1}$ Florida International University, Miami, FL, USA

${ }_{2}$ Nova Southeastern University, Ft. Lauderdale, FL, USA

${ }_{3}$ University of Puerto Rico, Medical Sciences Campus

\section{Corresponding Author:}

Georgina Silva-Suárez, MPHE, Florida International University, Robert Stempel College of Public Health and Social Work, Miami, FL, 33199,USA

Email: gsilv010@fiu.edu

\section{Acknowledgments}

I express my sincere gratitude to my dissertation committee for their guidance and dedication: Dr. Elena Bastida, Dr. Consuelo Beck-Sagué, Dr. H. Virginia McCoy, Dr. Mario De la Rosa and Dr. Silvia Rabionet. I would like to thank Dr. Carmen Zorrilla, Dr. Irma Febo, the staff of the University of Puerto Rico (UPR) Pediatric HIV/AIDS Research Program and CEMI and the Puerto Rico Mentoring Institute for HIV and Mental Health Research for supporting this study. Also, I would like to thank Dr. Annette B. Ramírez de Arellano, and my research assistant, Ana Carolina Arboleda, for their invaluable contributions to the study. I thank Florida International University, Graduate School for awarding me a Dissertation Year Fellowship. 


\section{Declaration of Conflicting Interests}

The authors declare no potential conflicts of interest with respect to the research, authorship, and/or publication of this article.

\section{Funding}

This research study was funded by the National Institute of Mental Health (NIMH) through the Puerto Rico Mentoring Institute for HIV and Mental Health Research (grant \# 1R25MH083617) and Florida International University, Dissertation Year Fellowship

\section{Biographical Information}

Georgina Silva-Suárez, MPHE, is a health educator and graduate student at Florida International University, Robert Stempel College of Public Health and Social Work Elena Bastida, PhD, is a professor in the Department of Health Promotion and Disease Prevention at the Robert Stempel College of Public Health and Social Work at Florida International University

Consuelo Beck-Sagué, MD, is an assistant professor in the Department of Health Promotion and Disease Prevention at the Robert Stempel College of Public Health and Social Work at Florida International University

Silvia E. Rabionet, EdD, is an associate professor in the College of Pharmacy at Nova Southeastern University and in the School of Public Health at the University of Puerto Rico, Medical Sciences Campus

Irma Febo, MD, is an associate professor in the Department of Pediatrics at the School of Medicine of the University of Puerto Rico, Medical Sciences Campus. She is the director of the UPR Pediatric HIV/AIDS Research Program 


\begin{abstract}
The present research used interpretative phenomenological analysis (IPA) to explore the life experiences of perinatally HIV-Infected (pHIV-I) youth in Puerto Rico. This article seeks to understand the impact of HIV disclosure on pHIV-I youth, and to capture their perceptions on disclosing their status to others. Twenty in-depth interviews were conducted and audio-recorded; these included questions about disclosure, and considerations before disclosing to others and to intimate partners. For study participants, the revelation that they had HIV was shocking. Although most suspected they had some type of disease because of their dependence on medications and frequent clinical visits, they did not conclude that they had HIV. However, by now, they have appropriated their HIV condition as something that is owned by them and their families. Most respondents said that disclosing their medical status to their intimate partners was one of "the most difficult things" they had to do. Although some experienced rejection, others found acceptance and support, with the majority reporting a sense of responsibility to themselves and to others. Findings presented here highlight the importance of the disclosure experience and their overall perceptions of this major life transition, which we find to be of importance to health professionals either in the treatment or prevention fields.
\end{abstract}

\title{
Key words:
}

HIV perinatally infected; Puerto Rico; interpretative phenomenological analysis; disclosure, adolescents 


\section{Introduction}

The lives of perinatally HIV-infected (pHIV-I) children have often been cloaked in silence and secrecy (Sherman, Bonanno, Wiener, \& Battles, 2000; Vijayan, Benin, Wagner, Romano, \& Andiman, 2009). Compared to children with other chronic diseases, pHIV-I children are less likely to be told about their illness (Hardy et al., 1994 as cited in Lesch et al., 2007). Worldwide, only a minority of them know their status. Although disclosure is more common in industrialized than in low- and middle-income countries, even in the former, only 30\%-40\% know their status (Pinzón-Iregui, Beck-Sagué \& Malow, 2013). Revealing their HIV diagnoses to children may require divulging family secrets as well as revealing the HIV diagnoses of other family members. Disclosure, therefore, has many dimensions, as it involves disclosing to the pHIV-I youth as well as to others.

The American Academy of Pediatrics (1999) has recommended disclosing HIV positive status to affected children as soon as it is developmentally appropriate. There are two types of disclosure: partial and full disclosure. In partial disclosure, the child knows something about the disease but is unaware of its name, lacks specific information about it, or does not know how he/she acquired it. Full disclosure involves revealing details of the disease to the child, including the name of the disease and specific information about it and how he/she acquired it, if the route of infection is known (Wiener, Mellins, Marhefka, \& Battles, 2007).

In order to facilitate the disclosure of HIV infection to pHIV-I children, the UPR Pediatric HIV/AIDS Research Program, the pediatric HIV comprehensive care unit of the University of Puerto Rico School of Medicine, “developed a structured clinical model for 
health professionals, caregivers, and family members” (Blasini et al., 2004, p.182). The disclosure model seeks to overcome stigma and helplessness and to empower patients and caregivers by giving them choices, information, and support (Blasini et al., 2004, p.183). The disclosure model has five components: (1) training seminars for health professionals; (2) caregiver educational and intervention sessions; (3) a patient education and intervention session; (4) a disclosure session; and (5) post-disclosure follow-up. Professionals who participate in the training session report a higher comfort level dealing with patients' disclosure. There is a significant increase among the caregivers who feel relief after disclosing (3\% vs 36\%, p <.001). Eighty percent of the youth consider disclosure of HIV infection as a positive event for them, and $90 \%$ of their families favor disclosure in general (Blasini et al., 2004, p. 186).

The second important aspect of disclosure is disclosing to others. The when, why, and who to disclose are among the questions adolescents living with HIV must address. Public health professionals work diligently to encourage judicious disclosure to prevent risky sexual behavior and transmission of the virus and drug resistance (Wiener et al., 2007). Perinatally-infected youth who may be willing to disclose their HIV status may, nevertheless, face a number of difficulties, including the uncertainty of others' reactions, fear of rejection, stigma, and fear of losing control of their personal information (Hogwood, Campbell, \& Butler, 2012). These youths are more likely to reveal their diagnosis in specific circumstances, such as being in a romantic relationship, getting married, having a child, and getting a job (Hogwood et al., 2012).

Moreover, perinatally-infected youth face other problematic situations related to disclosing their diagnosis. The families of some of these patients may encourage them to 
conceal or lie, or may prohibit their talking about their diagnosis because of fear of rejection and discrimination against them and/or their families (Sherman et al., 2000; Vijayan et al., 2009). These youths may, therefore, face conflicting advice. While health care providers and public health officials encourage them to reveal their diagnosis to their intimate partners; their families, on the other hand, may encourage them to conceal their illness as much and as long possible, sometimes all their lives.

Perinatally HIV-infected youth who know about their disease very early in their lives also know about the transmission of HIV and that using condoms is the most common preventive strategy to protect themselves and others against HIV transmission (Fernet et al., 2007). Those who are sexually active use condoms most of the time, even though they may not necessarily reveal their diagnosis to their partners (Fernet et al., 2007; Sanders, 2008). They may give a variety of reasons for using condoms, prevention of pregnancy being the most frequent rationale (Fernet et al., 2007). Because of the complexity of their situation, their sense of responsibility to others, and their fear of rejection, some may even choose to abstain from certain sexual activities or delay sexual intercourse to avoid full disclosure (Fernet et al., 2007).

The objectives of this article are twofold: (1) to explore the disclosure experience of pHIV-I youth in Puerto Rico which, as revealed by study participants, signaled a major turning point in their lives; and (2) to identify major experiential components in their narrative construction of their own disclosure to others. Capturing the voices of these young adults as they relate their everyday experiences of living with HIV in Puerto Rico provides insights and information about their life course trajectories and psychosocial aspects of their lived experience. Though individual life courses vary, disclosure of HIV 
diagnoses and age at the time of disclosure fluctuate and accordingly, support from family and friends may contrast throughout this time. Findings from this study reveal that the experience of disclosure itself is a major and impacting moment for all. Data presented here further indicate that those experiencing disclosure at an early age (as young as four), are likely to accept their condition as normal and construct their condition as any other personal characteristic, for example, height or hair color. For "tweens" or teenagers, however, learning about their diagnosis at this time in their lives may be quite traumatic, since it becomes intertwined wither relevant developmental changes, e.g. puberty, sexuality and other body changes.

\section{Methods}

This study used interpretative phenomenological analysis (IPA), a qualitative framework that aims to explore how people make sense of their everyday life experiences (Smith, Flowers, \& Larkin, 2009). Phenomenological research seeks to examine an experience or phenomenon "the way it occurs and in its own terms" (Smith et al., 2009, p. 12).

IPA is particularly appropriate in the study of HIV disclosure because the topic is one that leaves a deep imprint on informants' life experiences. Participants in this study could, therefore, vividly recall not only the circumstances under which they learned about their status, but also what disclosure meant to them.

However, it must be recognized that what they believe to "vividly recall" has been altered by the passing of time and repeatedly transformed in their memory recollections of the disclosure event. And thus this "vivid recall" is at best a reconstruction of that experience. For purposes of the material presented here, the exact details of the event are 
of little importance, however, the reconstruction of this experience is very much at the center of the discussion. It is not the accuracy of the event itself that is of importance here, but how this experience, however recalled, reconstructed or transformed many times over throughout the years has shaped and continues to shape the current unfolding of their lives.

\section{Sample Selection}

Purposeful sampling was used to recruit study participants. This sampling method seeks to select information-rich cases to study in depth (Patton, 1990). Powerful or rich cases are those "from which one can learn a great deal about issues of central importance to the purpose of the research" (Patton, 1990, p.169). The in-depth interview was selected as the method most suitable to collect participants' life experiences. Eligibility requirements include patients or former patients of the UPR Pediatric HIV/AIDS Research Program, who are perinatally HIV-infected; know their HIV status; are willing to share their life experiences.

\section{Recruitment}

The UPR Pediatric HIV/AIDS Research Program's staff physician, nurses, and/or social workers determined whether or not patients met the inclusion criteria when they attended the clinic for their routine visits. When potential participants met the inclusion criteria, UPR Pediatric HIV/AIDS Research Program staff invited them and their parent or guardian, when appropriate (i.e., when the potential participant was less than 21 years old), to participate in the research study. After participants and their parents agreed to participate, they were contacted by telephone by the first author who explained the purpose of the study and gauged their willingness to participate in an interview to explore 
their life experiences as pHIV-I youth living with HIV. Questions or concerns were clarified during the first contact call, and an interview appointment was scheduled. Participants and their parents or guardian (when needed) gave written informed consent.

\section{Interview Guide}

A set of open-ended questions was developed (See appendix A for the interview guide). Questions addressed the overarching goal of the study, which was to examine how pHIV-I youth describe the impact of HIV in their lives. In keeping with IPA framework, the questions sought to elicit both the respondents' experience with certain phenomena and how they interpreted these phenomena. The list of open-ended questions was then categorized into three major thematic areas: personal, social, and medical.

The interview guide was assessed by a group of experts on perinatal HIV infection that included a physician, a social worker, and a public health specialist. The group’s recommendations were incorporated into the interview guide, which included questions about disclosure and considerations about disclosing to others, with emphasis on intimate partners. Some of the experts' observations informed the ordering and wording of the questions. The interview guide was piloted with a potential participant, who reported feeling comfortable during the interview and thought that the questions were very appropriate and pertinent for pHIV-I youth in Puerto Rico. No changes were made after conducting the pilot. In keeping with the goal of IPA, the purpose of the interview was to learn how participants make sense of their various experiences, and report these in their own words. An overall hermeneutical interpretive approach was followed in which effort was made to explore how participants made sense of their lived experience, through reconstruction of their disclosure events. 
The Institutional Review Boards (IRBs) of the Florida International University and the University of Puerto Rico Medical Sciences Campus evaluated and approved the study protocol.

\section{Data Collection}

Twenty pHIV-I women and men between the ages of 18 to 30 years old were recruited and interviewed. The interview lasted between 45 and 90 minutes. Interviews were conducted in a non-judgmental, respectful environment at the Maternal Infant Study Center (CEMI, for its Spanish acronym), a sister clinic to the UPR Pediatric HIV/AIDS Research Program that also provides services to people living with HIV. All the interviews were conducted in Spanish, the native language of both study participants and the researcher. After completing the interview, each participant received a monetary amount to cover transportation and meal and other expenses for the day.

All interviews were audio recorded, then transcribed by the first author. Transcripts were sanitized by removing any comments that may have compromised confidentiality. A graduate research assistant, immersed in Puerto Rican culture and proficient in English and Spanish, translated all interviews ${ }^{4}$. It is noted, however, that the original Spanish text was used in conducting the qualitative analysis presented here; thus avoiding a third level of text interpretation as indicated in qualitative procedures.

\section{Data Analysis}

Transcripts were examined individually. Following the steps proposed by Smith et al. (2009), the researchers read and re-read each of the transcripts establishing the participant as the focus of analysis. Transcripts were examined in an open-minded,

\footnotetext{
${ }^{4}$ Four of the authors are native Spanish speakers. Each independently read and selected Spanish transcripts and cross validated the English translation.
} 
systematic, and exploratory manner. Initial observations were recorded along the margins of each transcript. In addition to the first author, transcripts were read by at least two other members of the research team and contributors to this paper. Passages from the interviews were then discussed with other team members in relation to situation and meaning construction, as suggested by the IPA approach.

The first exploratory stage of the analysis identified approximately 40 themes. These were narrowed down or consolidated according to the following criteria: (1) their recurrence within and across cases (how often they were mentioned); (2) their relevance to care and treatment; (3) the relationship across themes.

In exploring participants' constructions of their lived disclosure experience, eight interrelated and connected themes were selected. The selected themes were the following: the meaning of disclosure, consequences of knowing their diagnosis, feelings about information withholding and deception by caregivers, pre-disclosing considerations, disclosure to others, fear of rejection, institutional discrimination, and stigma and rejection. Figure 1 presents how these eight themes are connected to each other and how they contributed to a better understanding of participants' experiences regarding disclosure. Those experiences fall within two broader dimensions: learning about their HIV diagnosis; and disclosing their status to others. Each of these dimensions is used in organizing the data analysis and in interpreting the findings. 
Figure 1. Patterns and Connections Among Themes That Emerged During Phenomenological Analysis

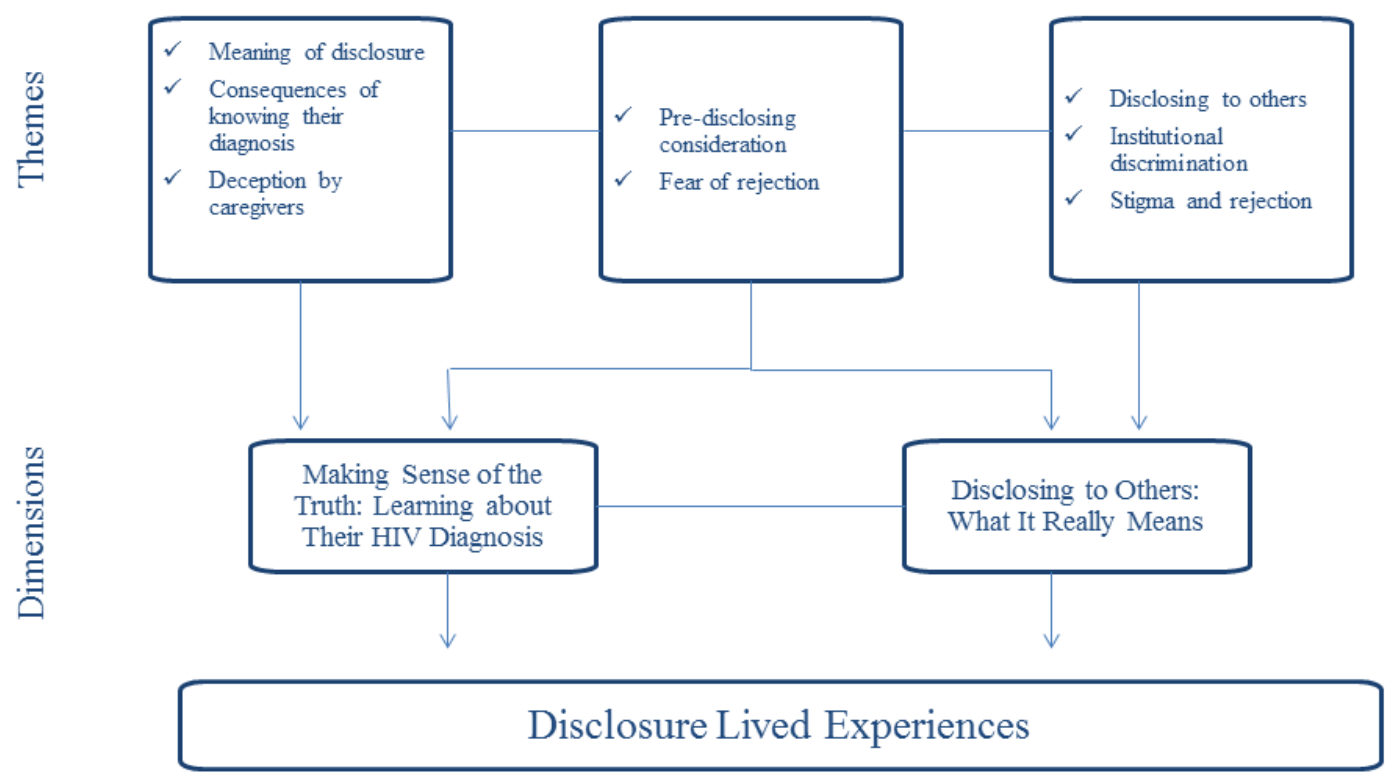

\section{Multiple Coding (Inter-Rater Reliability)}

In order to confirm the themes that emerged, 10 of 20 interview transcripts were assessed by two professionals, one in the area of human rights and the other in public health. Both identified major themes from the same 10 transcripts. The emerging themes were then cross-checked by each professional. When this procedure revealed discrepancies in topics, the coders clarified and discussed other possible interpretations, and refined or created a new code or theme. NVIVO 10 (QSR International, Burlington, and 2014 USA) qualitative analysis software was used to facilitate the systematic processing of the information generated by in-depth interviews. 


\section{Findings}

\section{Demographic Characteristics of the Study Population}

Among the 20 study participants eight were male and twelve were female.

Participants ranged in age from 18 to 29 years (mean age $=22$ years). Eighteen study

participants had completed high school and two had completed middle school. Only one study participant was married at the time of the interview; sixteen were single and three were cohabitating (see Table 1).

Table 1

Sample Demographic Characteristics by Gender

\begin{tabular}{lcc}
\hline \multicolumn{1}{c}{ Characteristics } & Male & Female \\
\hline Age distribution & 8 & 12 \\
$18-19$ & 3 & 2 \\
$20-21$ & 2 & 4 \\
$22-23$ & 1 & 4 \\
$24-25$ & 1 & 1 \\
$26-30$ & 1 & 1 \\
Highest Academic Degree Completed & \\
Middle School & 0 & 2 \\
High School & 8 & 10 \\
Marital Status & & \\
Single & 6 & 10 \\
Married & 1 & 0 \\
Cohabitating & 1 & 2 \\
Employed & & \\
Yes & 5 & 6 \\
No & 3 & 6 \\
Studying & 5 & 7 \\
Yes & 3 & \\
No & & \\
\hline & &
\end{tabular}




\section{Lived Experiences Regarding Disclosure}

Disclosure is a difficult topic for most study participants to discuss. The moment when they finally learned their HIV status was a definitive turning point in their lives Most participants confided that for them, the latter was a time in which important health information; critical to their survival was revealed. They further noted that this knowledge imposes a heavy social burden on them, because at some point in their lives they are likely to consider disclosing their status to others. The sharing of such personal information can be considered a second turning point in their lives.

Given the importance that participants attributed to disclosure the experiences, meanings and constructions of all aspects of the disclosure experience were explored throughout the interviews in accordance with following IPA procedures. In this manner the interviewer probed to obtain as much individual and detailed information as possible on these two major junctures in the life course of the respondents. Extensive information was compiled about participants’ life experiences when discovering their HIV status and when disclosing to others. The implications of these life events were introspectively examined by each participant as each constructed his or her own individual narrative about the experience.

The results section is divided into the two turning points: (1) learning about their HIV diagnosis; and (2) disclosing their status to others. Fragments of participants’ narratives were selected to support each of the themes; informants were given fictional names to protect their identities (see Appendix B for participants' quotes in the original Spanish). 


\section{Making Sense of the Truth: Learning about Their HIV Diagnosis}

Sixteen of the 20 participants recalled the age when their HIV diagnosis was revealed. On average, participants learned about their diagnosis at the age of 12 . The youngest found out her diagnosis when she was 4 years old; the oldest, when he was 18 years old. Thirteen participants learned about their diagnosis through the UPR Pediatric HIV/AIDS Research Program, oftentimes from a multidisciplinary team, which included a pediatrician, a psychologist, nurses and a social worker. The remaining participants did not recall how they learned their diagnosis, or found out through a parent or caregiver. Two of them said that they did not recall an exact moment when their diagnosis was revealed; both of them said that it was a gradual process: every time they had a question, that question was answered according to their age. Both were pleased with this type of disclosure. Two other participants were told by their parents and were satisfied with how their parents handled the disclosure.

Miranda, a 19-year old single head of household, narrates how her father revealed her HIV diagnosis:

[talking about who revealed her diagnosis] Umm, my dad. [WOULD YOU TELL ME WHAT THAT EXPERIENCE WAS LIKE?] Well, I took it in stride, because, well, I suspected it, because of all I saw in [UPR Pediatric HIV/AIDS Research Program]: the blood samples, the signs they always had around, so I already suspected it. But well I took it calmly when he told me, and I was like a little down at first, but I later took it all in. [AND IT WAS AT 9 YEARS OLD?] Yes. [WHY DID HE DECIDE TO TELL YOU?] Well, because I had asked him, why so many 
appointments, so many samples taken? So that's when he told me. And I was in shock for a moment, but later I took it all in.

Carla, a single 23-year old professional, observed that her mother decided to reveal her diagnosis on her way to the UPR Pediatric HIV/AIDS Research Program. As a result, Carla was able to clarify the information and her remaining doubts with HIV/AIDS Research Program personnel:

I found out because it was already time for my mom to tell me, according to the clinic's protocol and everything, because we were on our way to an appointment at [the UPR Pediatric HIV/AIDS Research Program]. [THEY TOLD YOU AT [THE UPR PEDIATRIC HIV/AIDS RESEARCH PROGRAM] ?] Yes, I was going to an appointment at [the UPR Pediatric HIV/AIDS Research Program] and we were talking on the way because I lived in (town in Puerto Rico) and mom and I started talking on the way while in traffic until she told me. [OH, YOUR MOM TOLD YOU?] Yes, she told me and then I talked to the doctors here at [the UPR Pediatric HIV/AIDS Research Program], the doctors talked to me and explained it to me. Because I didn't know; even then, I didn't know. [IT TOOK YOU BY SURPRISE?] Yes, yes...

Two other participants learned about their HIV status while they were hospitalized. For one of them, the revelation was extremely shocking: neither she nor her mother knew that she had HIV before that hospitalization. While she was very sick in the hospital, her mom told the physician that she herself was HIV positive and suggested that her daughter might be too. The daughter was 13 years old at the time, and learning that she had HIV like her mother was heart-breaking. 
The participant who discovered her HIV diagnosis at the youngest age was 4 years old. She said that she was watching TV when she saw Magic Johnson talking about HIV and the medicine he was taking. She recalls telling her mother that Magic's medicine was the same as hers so they must have the same disease.

Another study participant, Marina, a single 23-year old, remembers how the UPR Pediatric HIV/AIDS Research Program staff used a cartoon book to explain and to reveal her diagnosis. She said that after receiving the explanation with the book she understood. She explained the situation as follows:

Well, at the age of 9, they explained it to me with a little book. I remember, they put me there in a little room and they explained it to me with the little book. It's like there's the virus, which is bad, and the defenses are trying to fight it; and they told me. [AND WHO TOLD YOU?] Oh, I don't remember, haha. [BUT WAS IT IN YOUR HOUSE?] No, it was at [the UPR Pediatric HIV/AIDS Research Program]; they explained it to me with a little book, and I understood. What knowing their HIV diagnosis meant. Study participants differed in their reception to disclosure. Some reported that they had suspected something because of their medications and medical visits. These participants thought that they might have something because, contrary to their peers, they had to take medication and undergo medical check-ups regularly. When their diagnosis was revealed to them, most took it calmly. Others reported that, once they knew their diagnosis, they understood many odd things that had happened in their lives, such as their daily doses of medication and the loss of one or both parents. Marina was one of the participants who reported a greater understanding after learning her diagnosis: 
Well, greater understanding. Obviously, then I was also able to understand why my parents passed away... [] Everything kind of fell into place. And even at 9 years old one does not think about that, but, yes, then I became aware, that's why they gave me medication, that's why my parents died.

At the time they learned their diagnosis, study participants became aware of the social implications of having HIV. Isabel, a 22-year old mother of two whose condition was revealed at age 12, shared her fear of rejection and discrimination by her possible future partners:

Now, when I started to understand what it really was and what the diagnosis is and everything, it was very tough and I won't deny it. I went really crazy, I started thinking that no man was going to want me, umm, that I would disgust him or cause disgust in someone that I liked.

For others, the news was completely unexpected and shocking; they could not understand what was happening to them. For this group, discovering that they were HIV positive was very “tough to take in.” Some questioned "Why me?” Mauricio, a 19-year old, was one of the participants whose diagnosis surprised him:

Well, it was really a very difficult experience, because I never imagined I had that illness.

In the long run, they learned to live with their diagnosis and reported coming to grips and coping with their health situation. The majority of study participants understood the importance of taking care of their health. Some even reported that this knowledge requires that they be careful with themselves and with others. 


\section{Disclosing to Others: What It Really Means}

Their perception about disclosing. Two layers of social distance emerge when analyzing participants’ perceptions with reference to disclosing their HIV status. The first layer involves disclosing their HIV status to others in general; and the second, disclosing to special friends and intimate partners. That is, the latter relates to immediate kin, close friends and intimate partners in their private sphere; while the former involves the public sphere in their lives. Most study participants reported that they consider their HIV diagnosis as something within their private sphere, strictly their own, to be shared only with their family, but not with others. They, therefore, do not feel a need to disclose their status. Their argument is: if being HIV-infected is not an impediment in my life and if I can behave like a non-infected peer, why do I need to disclose it? Alonso’s quote reinforces this belief and attitude:

I don't, I don't talk about it publicly with everybody. You know, not everybody who knows me knows. Because it really isn't everybody; it's mostly my family. Because, if it doesn't affect me, why should I talk about it, if I can live life? (Alonso, 20 years old, married).

Marina claimed ownership of her diagnosis. In her own words, "it is something that belongs to me.” She continued:

Um, but um, it's like, again I tell you: HIV for me it's not something that I have to be disclosing or anything like that. It's a condition like arthritis, diabetes, that has to be treated and that's it.

Study participants who have disclosed their HIV status to special friends or to their partners described the event as "the most difficult thing they have done in their 
lives.” Most study participants felt an urge to reveal their HIV status to their partners or significant others. Despite their willingness to disclose and recognizing the importance of disclosing their status to their partners, some indicated that it was very difficult to disclose the information and they had no idea or guidance on how to begin. They also feared how the other person would react. Most went through a phase of constant rumination on whether or not to disclose.

Because of the importance attached to sharing this very private, personal and even painful information, respondents recalled the circumstances under which they disclosed their status to others. Probing on the part of the researcher revealed the meaning with which the youth imbue the topic of disclosure. One participant even said that she had participated in a role-play in which she rehearsed the conversation in which she would reveal her diagnosis to her boyfriend. Emma, a 20-year old college student, shared her experience and feelings when disclosing to her boyfriend:

It was very hard, it was the most difficult thing I've done in my life [REALLY?] It was very hard, I cried like I've never cried (she laughs) [BEFORE, AFTER OR DURING?] Throughout (both laugh). I didn't know how to start, I didn't know how to finish [].

Mauricio also shared his experience when disclosing to his girlfriend, and agreed with Emma that it was a difficult thing to do:

That was a year after, after, after we started dating, well we saw that the relationship was stable and that things would go well, and, well, I made the decision to tell her. Actually, it wasn't easy, because the first thought I had was rejection. I was afraid of being rejected, of having the relationship end, but thank 
God I had the courage, the strength, the resolve to tell her and, well, she listened to $\mathrm{me} . .$.

Responsibility to others and to themselves. Along with their diagnosis, pHIV-I youth reported a strong sense of responsibility to others. This is intrinsically related to having an intimate relationship. Most expressed feeling responsible for protecting their partners from HIV; they, therefore, felt an obligation to reveal their HIV diagnosis and to use condoms. Marina, who was not sexually active at the moment of the interview, shared her future educational and counseling plan for when a potential partner enters in her life:

But my plan is also, that when telling him, we would both be informed of how to take precautions, because even like this I want to be a mother. That is my dream and obviously he will worry, but what if my child comes out... you know. But I have it all planned out in my head, like that, once I see the commitment, telling him clearly and also both of us being informed.

Eugenio, a 19-year old student, mentioned how he feels regarding protecting his girlfriend:

I feel a great deal of responsibility. You know, it's as if I was carrying two pails of water on my back.

Arturo's narratives shows indicates the level of responsibility that pHIV-I youth feel and observe; they realize that they have to protect themselves as well as others: Well...is like any other illness: ...you have to treat it and you have to take care of yourself, you have to take care of others. We have to protect the people we're 
with. Sex is good, that isn't questioned and no one can say the contrary. But you have to be careful. [] There's no need to be selfish. (Arturo, 22 years old).

All study participants were aware of their condition and its transmissibility. In addition to protecting others from getting HIV, they also sought to protect themselves, becoming advocates for condom use. Alejandra, a 21-year old college student, expressed the following:

[] if there's no protection they're screwed because I don't do it without protection. Because... if you have something and I don't know and you haven't told me. I mean, there are people that don't say anything. They do what they do with other people, and they're off to the races... and I'm not like that.

A small number of the sexually-active participants decided not to reveal their diagnosis to their sexual partners. The most common reason for informants not revealing their HIV-status to their sexual partners was that they were not in a "serious" relationship. For these participants, a serious relationship is one in which they are committed to each other, in which they see a future together. Non-serious relationships are in their initial stages; for example, in which the duration of the relationship is unknown because the parties have known each other for a short time. Another type of non-serious relationship, as one participant noted, is one in which both individuals know that the relationship is not likely to last. Nevertheless, participants said that they always insist on using condoms during sex.

Although the majority of those interviewed reported being very cautious, one study participant said that he had had sex without condom and without disclosing his diagnosis to his sexual partner and now he is responsible for his partner's HIV-infection. 
Esteban, a 26-year old male and the only participant who reported being gay, also identified some difficulties regarding disclosing his HIV status within his "community," due to promiscuity and gossiping. Indecision about disclosure and his ambiguity toward his community proved costly, as indicated below:

The one I'm currently with, it just happened, after a long time, unfortunately, I had relations with him without protection and now he has it. [OKAY, BUT DID HE KNOW YOU HAD IT OR NOT?] No, I didn't tell him at that time, I didn't tell him but not with the intention of concealing it from him. It's that, in the moment, it happened in the moment and I lost control and whatever, when we finished it's when I fell into a crisis and regretted it and told him, right away, within the same hour and everything. Right away, I stopped him and I told him. And he only asked why I hadn't told him before and I was left like, in a daze, in a daze because, maybe some people say it spontaneously and I can say it spontaneously, but when a new relationship enters my life it's very...

Consideration before disclosing. The majority of the study participants agreed that before disclosing their HIV-status it is important to explore the level of mutual trustworthiness in the relationship. Some said they make sure that the other person is non-judgmental and understanding. For Alejandra, trust was a key element before disclosing her HIV-status:

Well, trust. So, if that person really trusts me and reveals personal things to me and well I have the same trust with that person revealing personal things. Well, that way eventually, look you know, a long-time friendship, I reveal the condition, as if it were normal. 
Others, such as Mauricio, said that they consider everything: level of understanding, trust, and even project the person's reaction:

Well, uh, everything, I always look at everything: that it's a person capable of understanding, that it's a person who understands, you know, who is capable, so to speak, who is a responsible person and who really has proved to be a sincere friend, male or female. You know that they're not there out of self-interest.

Victoria, an 18-year old nursing student, makes sure that the person to whom she reveals her diagnosis will not judge her:

...but for me it has to be, that they've gained my trust so that I can say, yes I know that this person won't judge me, or say anything, because a lot of people judge, "oh because you did and that" and then ask a lot of questions.

Timing of disclosure. The moment at which participants decide to reveal their diagnosis to their partners varies. Some study participants said that they reveal their diagnosis almost immediately after they meet possible partners. They explained that they do it that way because, if the person is going to reject them, it is better to know it at the beginning of the relationship. This is the case of Isabel:

If I'm meeting a man or a woman, even before a kiss, if I see that they like me and that I like them and that more than a kiss or a kiss can happen, I tell them, even if nothing happens, from the start. Because, because you don't know if after a kiss, you tell the person and the person doesn't understand and thinks that they could get it from a kiss and they might even want to kill you...

Others prefer to assess their relationship before disclosing. In some cases the delay in disclosing to intimate partners is not on purpose. Study participants who delay 
this process said that at the time, it happened, they wanted to tell their partners earlier, but they reported that the fear of rejection and not knowing how their partner would react contributed to their silence. Although they did not reveal anything, some said that keeping the secrecy surrounding their health situation worried them. This was the experience of Emma:

I told him, I think, after being with him 7 months. I wanted to tell him, I wanted to tell him. But I didn't know how to tell him because some rumors had reached him, and I had denied it. It was the beginning of the relationship. But he took it well. Mauricio shared a similar situation. He withheld his diagnosis from his girlfriend for one year. He wanted to make sure that they had a solid relationship before revealing his diagnosis. Like Emma, he was worried about his girlfriend's reaction to his diagnosis. He observed:

Yes. That was a year after, after, after we started dating, well we saw that the relationship was stable and that things would go well and well I made the decision to tell her. [ ]...it worried me a lot, a lot, I didn't know how she was going to take it, how she was going to react to that, you know because it's an illness for which there is no cure at present, you know, and, well, I lived in fear, I lived in fear of telling her.

One of the oldest study participants, Fernanda, a 29-year old housewife, said that when she was younger it was harder to let others know about her HIV-status. When she was 19 she was in a relationship and withheld her diagnosis; when she got pregnant she decided to let her partner know about her pregnancy and HIV-status. Her partner rejected her not because of having HIV but because she did not let him know earlier. 
I loved the father of my daughter and I did not tell him anything, and I got pregnant and all. Thank God, he is okay, but he remained angry, and did not even acknowledge the child. He[] found out when I got pregnant and I told him...look, I'm pregnant and this is what is happening and I told him about my condition. And then, what happened was what I had been afraid of ...he then rejected me, and threw me out of his house. []He got frightened and did not want to hear from me again. [AND WHY DO YOU THINK HE REJECTED YOU, FOR YOUR CONDITION OR...] Because, I had not told him, because I had not told him. Fear of rejection. Study participants said that the main reason for avoiding disclosing their HIV status is the fear of rejection and discrimination. The majority agreed that they fear how others will accept the diagnosis and how they will react. Even participants who have never experienced rejection expressed fear of being discriminated against or rejected. They reported knowing other HIV-positive youths who have been rejected because of their health condition. For example, Miranda:

What worries me is how he takes it, how he's going to react, because there are people who take it calmly, there are people who get angry and aggressive, and that's my fear.

Similarly Victoria expressed worries about being judged:

The bad thing is that they can judge you and they can hurt you; people whom you thought wouldn't hurt you, hurt you. [AND HAVE YOU EVER BEEN THROUGH THAT EXPERIENCE?] No, actually, up until now I've never been judged, or anything [AND WHERE DOES IT COME FROM...] I don't know, I've always felt that they could react badly, I don't know why. A lot of people react badly so I 
feel that they could react badly. [WHY DO YOU THINK THIS?] Because they did it to my sister, and I was there and I was left with that and I was like. [WHO TREATED HER BADLY?] A guy who was with her treated her badly and someone from the family, who didn't know and she told them and he treated her badly. So since then, I avoid telling them, and if I stay at a friend's house they always ask me "Why do you take medications?", and I say "it's for this thing or I make something up" because I never bring them in the bottle, I bring them separately in a container, like loose pills.

Consequences of disclosing. Study participants have experienced an array of consequences after revealing their HIV-status to others. Some suffered rejection and even institutional discrimination for being HIV positive. Fernanda reported being scheduled last for a cesarean because the institution claimed that the surgical suite would require a special cleansing following her C-section.

One time I experienced something strange, but it didn't bother me. But, it was when I had the girl because when I had the girl they did not see me until 2 o'clock and I heard the doctor when he said “...remember that she's an HIV patient, so we have to leave her for last" and it made me feel bad at the time.

Julia, a 25-year old employed mother of one child, was reproached for being "sick" when she got into an argument with her partner.

[ ]my daughter's dad is supportive but... he's supportive, but he let it slip once that "you," I don't know, we were fighting, that "it's that you're sick," and it hurt me, but he won't do it again. 
Additionally, revealing their diagnosis to others has placed these young adults in vulnerable situations. Some participants reported being victims of gossip and violation of confidentiality by those individuals to whom they revealed their diagnosis. Alejandra confided that she had to transfer to another school because she could not handle the gossiping and the talking after her friend divulged her HIV-status to other classmates: Well, I got to tell a friend of mine, but ...she didn't take it the way that I thought she was going to take it and well eventually everybody knew about it and so I changed schools.—SO, BECAUSE SHE DIVULGED THE INFORMATION??Yes, and well like nobody talked to me, because I was like the black sheep (she smiles) of the classroom. -AND WHAT GRADE WAS THAT?-Tenth. -AND DID YOU TELL ANYONE WHEN YOU SWITCHED SCHOOL?—NO. -UNTIL YOU LEFT_Yes, until I left, relaxed.

Others who also indicated having experienced discrimination indicated a more subtle style of rejection. For example, they explained that when they disclosed their HIV-status to others, oftentimes the other person seemed to accept them at first; however as time passed they noticed that those persons kept their distance and eventually disappeared from their lives.

Kathy, a 21-year old self-employed woman, interpreted her experience after she divulged to friends:

It changes. [CHANGES?] Yes. [FOR THE BETTER? FOR WORSE?] Many times, most of the times I've experienced it has been for worse. [FOR WORSE? WHAT'S THE REACTION?] They drift apart, you know, little by little... first they 
say "oh that's nothing" to not make you feel bad but in time you realize that they've stayed away.

Others who had disclosed their HIV status to their close friends, partners or others reported the disclosure as a positive experience. Some reported a small brief phase of disbelief from the persons to whom they revealed their diagnosis, followed by acceptance. These participants agreed that acceptance had been a positive experience for them: they felt empowered and loved. This is supported by Mauricio when sharing his experience:

Thank God she accepted my condition and that experience also helped me to accept myself, to accept my condition, and it helped me to improve my selfesteem.

Emma reconstructed what first appeared as her partner's rejection: At first he was shocked because he had to live with his parents who were, how do I say it, drug addicts, and when I told him that [her diagnosis] and he was, like, "Wow!" And well, I said to him that day, hey let's leave it at that, because it was already... umm he left, but he returned. But because I had gone to bed, he left me a letter, but he didn't give it to me, he was like umm, I'm not going to give her anything, but he threw it, over there. But because I was there, then I got it, I found it. And he called to see how I was and then the next day we got together again because he said he didn't mind.

A response of shock followed by acceptance was also experienced by Victoria when she revealed her HIV diagnosis to her friends. In her words, 
... they were in shock but, they were not judgmental; they were left like "really, I can't believe it." And, I don't know, but they were always there. No, they were never like we're going to leave you. [AND THEY'RE STILL YOUR FRIENDS?] Yes. [AND WHY DID YOU DECIDE TO TELL THEM?] Because they've always been with me and they tell me all their things so, I didn't, I didn't want to feel like I was hiding something. Whenever I give my friendship it has to be sincere; if not, then there's nothing.

\section{Discussion}

In keeping with findings reported by other studies, participants learned the truth about their health status when they were approximately 12 years old (Butler et al., 2009; Dorrell \& Katz, 2014; Fernet et al., 2007). They found out about their diagnosis through diverse of ways, although the majority of them say they learned it through the UPR Pediatric HIV/AIDS Research Program. This is not surprising, since all participants were UPR Pediatric HIV/AIDS Research Program patients or former patients, most since the time of their birth. The UPR Pediatric HIV/AIDS Research Program is one of the few HIV clinics that has developed its own disclosure model for HIV pediatric patients. As study participants indicated, most experienced the revelation of their diagnosis in the company of a multidisciplinary team. This reflects the UPR Pediatric HIV/AIDS Research Program disclosure model. One participant reconstructed the moment in which her diagnosis was revealed to her. She narrates how a member of the multidisciplinary team used a book of cartoons when revealing her diagnosis. She acknowledged that the book helped her to better understand her diagnosis and the information she was receiving 
at the time. The book is just one of the tools the UPR Pediatric HIV/AIDS Research Program staff use in their disclosure sessions.

Blasini et al. (2004) found that 78\% of the participants in their study did not suspect their HIV diagnosis; they believed they had other illnesses, such as a heart condition (10\%), kidney disease (3\%) or cancer (5\%). Similarly, some participants in the current study also suspected they might have something because of their clinical visits and need for medication. And, similarly to the findings by Blasini’s et al. (2004), most study participants did not know they had HIV. As expressed by study participants, learning their HIV diagnosis helped them to better understand their health situation, medication intake, and their clinical visits. Moreover, some study participants, after reconstructing their disclosure experience, indicated that learning their HIV-status helped them to understand odd things or tragic events in their lives such as losing one or both parents around the same period of time.

For the youths interviewed in this study, knowing and understanding their health status meant more than recognizing a responsibility to themselves and others. Disclosure marked a turning point in their lives and altered the course of their lives dramatically and forever (Elder, 1998).

The life course is often accompanied by transitions -changes in roles, statuses, and trajectories -longer term patterns of stability or changes (Hutchison, 2010). As shown in this study, the life course of pHIV-I youth has been full of transitions. When study participants were children they were living as "healthy and normal” children since most were unaware of their diagnosis. As they learned their diagnosis, they faced one of many turning points in their lives. And this juncture was accompanied by a change in 
their respective trajectories. As revealed in their narratives, they constructed their own perspectives from that of a "healthy" and "normal" child or youth to a child or youth with a chronic and stigmatizing health situation. Some reported that this event produced anxiety, fear, and discomfort. When assessing their life experiences they noted that, as time passed and they internalized their health situation, their perceptions of themselves also changed. Even after struggling with what at the time marked a tragic discovery about themselves, with time they began to acknowledge, understand and accept this imposed transition in their life course. In the end, they perceive themselves as "normal" and capable of achieving anything they want. They have accepted that some life situations will be different for them, but have rejected the idea that they should feel or be treated differently from their non-infected peers.

Study participants were emphatic in stressing ownership of their diagnosis, while also insisting on its privacy, and thus it should be kept in the private and not public sphere. When the researcher probed about their perception of disclosing their HIV-status to others, most participants said that, in some situations, it is not necessary to do so. Blasini et al. (2004), Fielden et al. (2006) and Michaud et al. (2010) reported similar findings: many HIV-infected youth choose to avoid disclosing their HIV diagnosis to others. According to Hogwood et al. (2012), revealing their HIV status to others is intrinsically linked with their intimate or love relationships. Similarly to Vijayan et al. (2009) and Wiener \& Battles findings (2006), our study participants acknowledge that disclosing their HIV diagnosis to a romantic partner was one of the most difficult things they must routinely confront. Even when study participants expressed their desire and 
will to reveal their diagnosis to their partners, most acknowledged not knowing how to begin; they also expressed fear of being rejected by the person they love.

Participants said that, before revealing their HIV diagnosis to someone, they needed to trust that person and to have a sense of how he/she would react to the disclosure. Revealing their status was very common when they were engaged in a committed relationship. When they do not consider a relationship as "serious," most do not reveal their diagnosis; still, most advocate for condom use.

IPA explores not only a person's experience, but also what it means to them. Disclosure of HIV status, as revealed in this study, suggests that a person's experience is often colored by that of others. Thus, while some participants reported not having experienced rejection themselves, they know that it has happened to others. They are therefore cautious and even fearful of revealing to others their condition.

Almost all study participants concurred that at some point in their lives, they have feared rejection. Some participants reported being rejected by their friends after disclosing their HIV status. Others fear rejection even when they have never experienced it in their lives. They have learned about rejection as a result of the generalized social stigmatization of HIV and through the experiences of other HIV positive friends or relatives.

Life experiences following disclosure vary. Some said they had experienced rejection and even been discriminated against, while others reported being accepted. Some mentioned that the social support that they received after the revelation of their HIV status served to reassure them that they were worthy individuals. This also helped them to feel a sense of mastery over HIV by increasing their self-esteem and confidence. 


\section{Conclusion and Implications}

Most study participants recognized that learning their HIV diagnosis was one of the biggest moments in their lives, and thus all agreed that it marked a major transition in their life course. They expressed that being surrounded by family and caring health professionals made a difference in how they coped with their diagnosis. The majority of study participants expressed feeling supported by their health care providers and were pleased with the method UPR Pediatric HIV/AIDS Research Program staff use to reveal HIV-diagnosis. This finding could be related to the UPR Pediatric HIV/AIDS Research Program's disclosure model, which not only deals with patients' needs, but also addresses the needs of families and health professionals.

It is not easy to cope with having a highly stigmatized chronic birth condition However, as revealed in the interviews, pHIV-I youth in this study have learned to manage their health status and its social consequences. They consider themselves overachievers because they have not only overcome and dealt with diverse life challenges, such as losing their parents and social stigmatization, but also faced the anxieties and insecurities of adolescence and puberty.

One important aspect of qualitative studies is that they enable participants' voices to be heard. These voices inform the scientific world about individual journeys through major life turning points, such as disclosure, all from participants' perspective. The use of IPA in this study, therefore, captured participants’ perspectives and their understanding of their disclosure experiences, a complex topic that is often poorly understood. 
Participants’ perspectives regarding disclosing to others were clear: they affirm ownership of their diagnosis, which as they observed, "belongs to them and their families.” In order to safeguard their will regarding their diagnosis -keep it from themselves and their families- the public perception of disclosure has to be modified. When these patients are labeled as "public hazards," it is not difficult to understand their choice to not disclose to others. In some situations, maintaining confidentiality is not easy. In the United States, 23 states have laws that require HIV patients to disclose their status (Galletly \& Pinkerton, 2006). Laws criminalizing HIV patients by forcing them to disclose to their intimate partners or to persons with whom they have any sexual contact go against the grain of our patients' will and life experiences. At the UPR Pediatric HIV/AIDS Research Program, for example, study participants have received much more than clinical treatment; most have also received information regarding how to protect themselves and how to protect others, emphasizing condom use.

Based on their lived experiences, perceptions, and interpretations of these experiences within their personal and societal context, study participants recognized their responsibility to protect their partners against HIV infection. However, they also believe that the responsibility to protect and prevent HIV infection should be a shared one, not exclusively theirs. The current generalized discussion and prescriptions on discourse has to be evaluated. When participants openly discuss their disclosure experience, they are reporting not just from their own individual position but also representing the societal perspective. Public health and prevention efforts regarding HIV need to include the general population. Several research studies have found that the pHIV-I population is very much aware of the transmissibility of infection and that the use of condom is an 
effective way to prevent HIV infection (Blake, Robley, \& Taylor, 2012; Fernet et al, 2007; Marhefka et al, 2011). If the general public were to attain the same sense of responsibility to themselves and to others that pHIV-I youth have achieved, HIV transmission could be lowered. From this perspective, participants' decisions on whether or not to disclose should be protected.

Finally, the experience of the one participant in the study who reported he was gay highlights the need to explore the lived experiences of gay or lesbian pHIV-I youth. Their life experiences and trajectories could be different from those of heterosexual youth, as clearly expressed by this one participant. He observed that within "his community” ---referring to the gay community--- he has had to deal with issues such as promiscuity, which made it more difficult to disclose his status to others. From a public health perspective, it behooves researchers and practitioners to further explore the life experiences of the Puerto Rican gay community in order to obtain a better understanding of this community and more effectively target interventions to meet their particular needs.

IPA seeks to gather the essence of participants’ lived experiences regarding sensitive or complex topics that are poorly understood or unexplored (McCormack, L., 2010). While the topic of disclosure has been studied previously, the IPA approach followed in this study, allowed for the collection of information on participants’ interpretation of their own experiences when first learning about their disease and when they disclose their status to others. This provides essential information to better understand their reality. Although findings from this study cannot be generalized, the lived experiences reported here can help to inform public health practices and services 
aimed at this population in Puerto Rico as well as in New York City and Florida, which have large populations of Puerto Ricans and others of Latin descent. 


\section{References}

American Academy of Pediatrics Committee on Pediatrics AIDS. (1999). Disclosure of illness status to children and adolescents with HIV infection. Pediatrics, 103(1), 164-166.

Blake, B., Robley, L., \& Taylor, G. (2012, November-December). A lion in the room: Youth living with HIV. Pediatric Nursing, 38(6), 311-318.

Blasini, I., Chantry, C., Cruz, C., Otríz, L., Salabarría, I., Scalley, N., . . . Díaz, C. (2004). Disclosrue model for pediatric patients living with HIV in Puerto Rico: Design, implementation, and evaluation. Developmental and Behavioral Pediatrics, 25, 181-189.

Butler, A., Williams, P., Howland, L., Storm, D. H., Seage, G., \& Team, T. P. (2009). Impact of disclosure on health -related quality of life among children and adolescents living with HIV infection. Pediatrics, 123, 935-943. doi:10.1542/peds.2008-1290

Dorrell, J., \& Katz, J. (2014). 'You're HIV Positive': Perinatally infected young people's accounts of the critical moment of finding out their diagnosis. AIDS Care, 26(4), 454-458. Retrieved from http://dx.doi.org/10.1080/09540121.2013.841833

Elder, G. H. (1998, Feb). The life course as developmental theory. Child Development, 69(1), 1-12. Retrieved April 2014, from http://www.jstor.org/stable/1132065

Fernet, M., Proulz-Boucher, K., Richard, M., Lévy, J., Otis, J., Samson, J., . . Trottier, G. (2007). Issues of sexuality and prevention among adolescents living with HIV/AIDS since birth. The Canadian Journal of Human Sexuality, 16(3-4), 101111.

Fielden, S. J., Sheckter, L., Chapman, G. E., Alimenti, A., Forbes, J. C., Sheps, S., \& ... Frankish, J. C. (2006). Growing up: Perspectives of children, families and service providers regarding the needs of older children with perinatally-acquired HIV. AIDS Care, 18(8), 1050-1053. doi:10.1080/09540120600581460

Galletly, C., \& Pinkerton, S. (2006, June 28). Conflicting messages: How criminal HIV disclosure laws undermine public health efforts to control the spread of HIV. AIDS Behavior, 10, 451-461. doi:10.1007/s10461-006-9117-3

Hogwood, J., Campbell, T., \& Butler, S. (2012). I wish I could tell you but I can't: Adolescents with perinatally acquired HIV and their dilemmas around selfdisclosure. Clinical Child Psychology and Psychiatry, 0(0), 1-17.

Hutchison, E. D. (2010). A life course perspective. In E. D. Hutchison, Dimensions of human behavior: The changing life course (pp. 1-38). Thousand Oaks, California: SAGE Publications. 
Lesch, A., Swartz, L., Kagee, A., Moodley, K., Kafaar, Z., Myer, L., \& Cotton, M. (2007, July). Paediatric HIV/AIDS disclosure: towards a developmental and processoriented approach. AIDS care, 19(6), 811-816. doi:10.1080/09540120601129301

Marhefka, S. L., Valentin, C. R., Pinto, R. M., Demetriou, N., Wiznia, A., \& Mellins, C. A. (2011). "I feel like I'm carrying a weapon.” Information and motivations related to sexual risk among girls with perinatally acquired HIV. AIDS Care, 23(10), 1321; 1321-1328; 1328.

McCormack, L. (2010). Primary and vicarious posttraumatic growth following genocide, war and humanitarian emergencies: An interpretative phenomenological analysis. (Doctoral dissertation). University of Nottingham, Nottingham, United Kingdom.

Michaud, P., Suris, J., Thomas, R., Gnehm, H., Cheseaux, J., \& MoCHIV. (2010). Coping with an HIV infection. Swiss Med Wkly, 140(17-18), 247-253.

Patton, M. Q. (1990). Qualitative evaluation and research methods. Thousand Oaks, CA: Sage Publications, Inc.

Pinzón-Iregui, M. C., Beck-Sagué, C. M., \& Malow, R. M. (2013). Disclosure of their HIV status to infected children: A review of the literature. Journal of Tropical Pediatrics, 59(2), 84-89. doi:10.1093/tropej/fms052

Sanders, L. (2008, Feb). Women's voices: The lived experience of pregnancy and motherhood after diagnosis with HIV. Journal of Association of Nurses in AIDS Care, 19(1), 47-57. doi:10.1016/j.jana.2007.10.002

Sherman, B., Bonanno, G., Wiener, L., \& Battles, H. (2000). When children tell their friends they have AIDS: Possible consequences for psychological well-being and disease progression. Psychosomatic Medicine, 62, 238-247.

Smith, J., Flowers, P., \& Larkin, M. (2009). Interpretative Phenomenological Analysis: Theory, Method and Research. Thousand Oaks, California: SAGE, Inc.

Vijayan, T., Benin, A. L., Wagner, K., Romano, S., \& Andiman, W. A. (2009). We never thought this would happen: transitioning care of adolescents with perinatally. AIDS Care, 21(10), 1222-1229. doi:10.1080/09540120902730054

Wiener, L., \& Battles, H. (2006). Untangling the web: A close look at diagnosis disclosure among HIV-infected adolescents. Journal of Adolescent Health, 38, 307-309. doi:10.1016/j.jadohealth.2005.03.024

Wiener, L., Mellins, A., Marhefka, S., \& Battles, H. (2007). Disclosure of an HIV diagnosis to children: History, current research, and future steps. $J$ Dev Behav Pediatr, 28(2), 155-166. 


\section{Appendix A}

\section{Interview Guide}

\section{Personal Life}

- How would you describe yourself?

o Happy, nervous, positive, negative, etc.

- What do you like to do in your leisure time?

- Do you have any goals you want to achieve in the future?

- What does “disease” mean to you?

- What does "HIV" mean to you?

- When did you find out about your diagnosis?

o How?

o Who told you?

o What did it mean to you?

- How would you describe your life before and after your diagnosis?

- How do you cope with your diagnosis?

- Have you considered becoming a parent?

- If she/he is, what has the experience been like?

- If she/he isn't what are your thoughts about it?

$\underline{\text { Social Aspects }}$

- What does "family" mean to you?

- Who have been the most meaningful people for you?

- Tell me more about your parents, who are or were they?

- How do you feel about your parents or what do you think about them?

- In your opinion, how does your family deal with HIV?

- Tell me about your experience at school, university or work environment?

- What do you consider most important before disclosing your diagnosis to others?

- Do your siblings or other family members know about your diagnosis?

- What do you consider are the pros and cons of disclosing your diagnosis? 
- What does "friendship" mean to you?

- What are your thoughts about intimacy in a relationship?

- Do you disclose your HIV status with intimate partners?

- Does your diagnosis have implications in your personal relationships? Positive? Negative? Would you give me an example?

\section{Medical Aspects}

- Tell me about your experiences with your health care providers (physicians, nurses, pharmacists, emergency room personnel, etc.)

- How long have you been taking medications?

- What does “medication” mean to you?

- What factors facilitate (or not) taking your medications?

- What additional services would you like to receive?

- How do you feel about your transition to adult care?

o How do you envision your adult care?

- What do you think about PREP for prevention? 


\section{Appendix B}

\section{Spanish quotes for the manuscript:}

\section{Reconstructing the Truth: The Life Experiences of Puerto Rican Perinatally HIV-}

\section{Infected Youth with Disclosure}

- [Hablando sobre quien le reveló su diagnóstico]Esto, mi papá. [ME CONTARIAS COMO FUE ESA EXPERIENCIA?] Pues lo tome normal, porque pues como me imaginaba lo de la condición, porque lo veía todo en [la clínica], las muestras de sangre, los rótulos que siempre tenían por ahí, pues como ya me imaginaba. Pero pues lo tomé tranquila cuando él me lo dijo y como estuve así como que un poquito down al principio, pero después lo asimilé. [Y FUE A LOS 9 AÑOS] Sí. [¿¿POR QUE EL DECIDIO DECIRTELO?] Pues porque yo le había preguntado que por qué tantas citas, tantas sacadera de muestras, entonces pues fue ahí que él me lo dijo. Y me quedé como que en shock por un momento, pero después lo asimilé (Miranda, 19 años).

- Me entere porque ya era el momento en que mami me lo tenía que decir, por protocolo de la clínica y todo, pues veníamos para una cita en [la clínica]. [¿FUE EN [LA CLÍNICA] QUE TE LO DIJERON?] Sí, venía para una cita en [la clínica] y veníamos hablando por el camino porque vivía en (pueblo de PR) y empezamos hablar mami y yo en el tapón por el camino hasta que me lo dijo. [AH, ¿TE LO DIJO TU MAMÁ?] Sí, me lo dijo y entonces acá en [la clínica] pues hablé con las doctoras, las doctoras me hablaron y me explicaron. Porque yo no sabía, a todas estas yo no tenía conocimiento. [TE TOMÓ POR SORPRESA?] Sí, sí (Carla, 23 años). 
- Pues a los 9 años, me lo explicaron con un librito y me acuerdo, me pusieron así en un saloncito pequeño y me lo explicaron con el librito. Como que esta el virus que es malo y las defensas tratando de pelearlo y me lo dijeron. -y quién te lo dijo?- Ay no me acuerdo jaja. - ¿Pero fue en tu casa?- No, fue en[ la clínica de VIH/SIDA de la Universidad de Puerto Rico]. Me explicaron con un librito, y pues entendí (Marina, 23 años).

- Bueno, más entendimiento. Obviamente, también ahí pude entender porque mis padres fallecieron [] todo como que encajó, y aún a los 9 años uno no piensa en eso, pero sí ahí yo encajé, por eso a mí me dan medicinas, por eso mis papas fallecieron (Marina, 23 años).

- Ahora, cuando empecé a entender que realmente era y como es que es el diagnóstico y todo, fue bien fuerte y no lo voy a negar. Yo me volví bien loca, este yo empecé a pensar que ningún hombre me iba a querer, este que yo lo que podía era darle asco o causarle asco o desprecio a una persona, a una persona que me gustara (Isabel, 22 años).

- Bueno, pues fue una experiencia de verdad bien fuerte, porque jamás y nunca me imaginé que tenía esa enfermedad (Mauricio, 19 años).

- Que en parte viste, yo no, yo no lo hablo públicamente con todo el mundo, tu sabes no todo el mundo que me conoce sabe, porque en verdad no es to' el mundo es mayormente mi familia, porque es como yo digo, si a mí no me afecta para que tener que decirlo, si yo puedo vivir la vida (Alonso, 20 años). 
- Este, pero eh, es como que, vuelvo y le digo el VIH para mí no es algo que yo tenga que estar ni divulgando, ni nada por el estilo, es como una condición como la artritis, la diabetes, que hay que tratarla y ya (Marina, 23 años).

- Fue bien difícil, fue lo más difícil que he hecho en mi vida [DE VERDAD] fue bien difícil, lloré como nunca (se ríe) [ANTES, DESPUES O DURANTE] todos (carcajadas de ambas). No sabía cómo empezar, no sabía cómo terminar [] (Emma, 20 años).

- Eso fue un año después de, de, de que nos hicimos novios, pues vimos que la relación era estable y que nos podía ir bien y tomé la decisión pues de contarle. De hecho, no fue nada fácil, porque el primer pensamiento que me vino fue el rechazo. Tenía miedo al rechazo, a que la relación se rompiera, pero pues gracias a Dios tuve el valor, la fuerza, la determinación de contarle y pues ella me escuchó... (Mauricio, 19 años).

- Pero mi plan también es, que al yo decírselo, seamos orientado los dos de cómo, tener cuidado, porque aun así yo quiero ser madre, ese es mi anhelo y obviamente va a ser preocupación de él, pero si mi hijo sale...tu sabes. Pero yo lo tengo planificado en mi cabeza, así de que sí cuando ya yo vea el compromiso, decírselo claro y también ser orientados los dos... (Marina, 23 años).

- Me siento responsable, pero una cosa inmensa. Tu sabes, es como si tuviera dos baldes de agua en mi espalda (Eugenio, 19 años).

- Pues que nada, que esto es como cualquier enfermedad, que hay que tratarla y hay que cuidarse, hay que cuidar a los demás. Hay que cuidar a las personas con las que estamos. El sexo es bueno, eso no se niega y nadie puede decir lo contrario, pero hay 
que cuidarse. Yo lo he sabido hacer y tengo dos hijos hermosos, bellos y preciosos y son negativos. Y la madre de mis hijos es negativa y compartimos por 5 años, así que se puede, se puede hacer, sin afectar la vida de otro. No hay por que ser egoísta (Arturo, 22 años).

- Si, y si no hay protección están ‘chavao’ porque yo no lo hago sin protección, porque y si tú tienes algo y yo no sé y tú no me lo has dicho. O sea, hay personas que no dicen nada, hacen lo que hacen con otras personas y vámonos que es tarde. -UJUMy yo no soy así (Alejandra, 21 años).

- El que estoy ahora, da la casualidad que después de tanto tiempo, de mala suerte, estuve con él y estuve sin protección y él lo tiene. [OKAY, PERO EL SABIA QUE TU LO TENIAS O NO?] No, al momento de estar con él no se lo había dicho, yo no se lo había dicho y no por no decírselo, es como, en el momento, en el momento pasó y me descontrolé y whatever, cuando yo terminó de hacerlo ahí es que caigo en crisis y lo siento y se lo digo, ahí en el mismo momento, la misma hora y todo. En el momento, lo paro y le digo y solamente lo que me dijo es que por que no se lo había dicho antes y me quedé como, en un viaje, me quede en un viaje porque, algunas personas a lo mejor lo dicen espontáneamente y yo lo puedo decir espontáneamente pero al momento de llegar una relación a mi vida eso es bien... (Esteban, 26 años).

- Pues la confianza. O sea, si esa persona de verdad tiene confianza en mí, en revelarme cosas personales y pues yo tenía la misma confianza con esa persona de revelarle cosas personales, pues así eventualmente, mira tu sabes, mucho tiempo de amistad, le revelo la condición, como que normal (Alejandra, 21 años). 
- Bueno, eh, todo, siempre brego todo, que sea una persona capaz de entender, que sea una persona entendida, tu sabes capacitada por decirlo así, que sea una persona este responsable y que de verdad denote que es un amigo o una amiga sincera. Tu sabes que no está por interés (Mauricio, 19 años).

- pero para mí tiene que ser, que sea haya ganado mi confianza que yo puedo decir, mira en verdad yo sé que esa persona no me va a juzgar, ni va a decir nada, porque mucha gente juzga, 'ah que si tú, que porque’ y después muchas preguntas, (Victoria, 18 años).

- Si yo voy a conocer un hombre o una mujer, antes de hasta un beso, si ya yo veo que yo le agrado a la persona y que la persona me agrada a mí y que puede pasar más de un beso o un beso, yo lo digo, aunque no pase nada, desde el principio. Por qué, porque tú no sabes si después de un beso, tú le dices a la personas y la persona no entienda y se crea que por un beso se lo vas a pegar y te quieran hasta matar (Isabel, 22 años).

- Se lo dije creo que fue a los 7 meses de estar con él. [ ] Sí, hay yo decía, se lo quiero decir, se lo quiero decir, no sabía la manera de cómo decírselo, porque le habían llegado rumores, pero yo se lo había negado, era al principio de la relación. Y pero lo tomó bien (Emma, 20 años).

- Sí. Eso fue un año después de, de, de que nos hicimos novios, pues vimos que la relación era estable y que nos podía ir bien y tomé la decisión pues de contarle. [ ] Me preocupaba bastante, bastante, no sabía cómo lo iba a tomar, como lo iba a reaccionar ante eso, tu sabes porque es una enfermedad que hasta ahora no tienen 
cura, tu sabes y pues vivía con miedo, vivía con miedo de contarle (Mauricio, 19 años).

- El papa de mi nena a mí me encantaba y yo no le dije nada y salí embarazada y todo, gracias a Dios él no tiene nada pero él se quedó con ese rancor, y ni siquiera a la nena reconoció. El [ ] se enteró cuando yo salí embarazada y yo le dije, que yo le dije, mira estoy embarazada y esta es la que hay y le dije lo de mi condición y ahí pues, pasó lo que yo tanto miedo le tenía, sucedió ahí porque me rechazo, me boto de su casa. [] Cogió miedo y no quiso saber más de mí. [Y PORQUE TU CREES QUE TE RECHAZO, POR LA CONDICION O....] Porque no se lo dije, porque no se lo dije (Fernanda, 29 años).

- Lo que me preocupa es cómo lo tome, cómo él vaya a reaccionar, porque hay gente que reacciona tranquilo, hay gente que me reacciona como enfogono agresivo y ese es mi temor (Miranda, 19 años).

- Lo malo es que te pueden juzgar y te pueden lastimar, personas que tu pensabas que no te iban a lastimar, te lastiman. [¿Y HAS PASADO POR ESA EXPERIENCIA EN ALGUN MOMENTO?] Fíjate, no, hasta ahora no he pasado por nada que me juzguen, ni nada [Y DE DONDE VIENE, ESE...] Es que no sé, siempre está en mi que pueden reaccionar mal, no se por qué. Muchas persona reaccionan mal y pues, yo siento que podrían reaccionar mal. [¿POR QUE TU CREES?] Por a mi hermana se lo hicieron, y yo estaba y me quedé con esa y yo como que. [¿QUIEN LA TRATO MAL?] Un muchacho que estaba con ella, la trató mal y alguien de la familia también, que no lo sabía y ella se lo dijo y la trato mal y yo desde ese entonces, evito decirle, y siempre me preguntan 'porque tu tomas medicamentos' si me quedo en 
casa de amistades, y yo 'que si es por algo o me invento algo' porque yo nunca los llevo en los frascos, yo las llevo sueltas en el cosito, pastillitas así suelta (Victoria, 18 años).

- Una vez, vi algo raro, pero no me molestó pero, que fue cuando yo tuve la nena pero cuando yo tuve la nena a mí me dejaron pa' las dos de la tarde y yo escuché a un médico cuando le dijo 'no acuérdate que ella es paciente VIH y hay que dejarla pa' lo último' y a mí eso me hizo sentir mal en aquel momento (Fernanda, 29 años).

- [ ] el pai de mi hija, me apoya pero... él me apoya, pero una vez se le safó, que si tú, que se yo, peleando, pero es que tu estas enferma, y eso me dolió, pero ya no lo vuelve a hacer (Julia, 25 años).

- Pues llegué a contárselo a una amiga mía, pero pues no lo tomó como pensé que lo iba a tomar y pues eventualmente todo el mundo supo de eso y pues me cambié de colegio. -O SEA, ¿POR QUÉ ELLA DIVULGÓ LA INFORMACIÓN?- Sí, y pues como que nadie me hablaba, pues yo era como que la ovejita negra (se sonrie) del salón. - ¿Y EN QUÉ GRADO FUE ESO?- Pa' décimo. - ¿Y EN EL OTRO COLEGIO, CUANDO TE CAMBIASTE, LE DIJISTE A ALGUIEN?- No. -HASTA QUE SALISTE- Sí, hasta me salí, tranquila (Alejandra, 21 años).

- Cambia. [¿CAMBIA?] Sí. [¿PARA BIEN?, ¿PARA MAL?] Muchas veces, la mayoría de las veces que me han tocado para mal. [¿ंPARA MAL?, ¿CUÁL ES LA REACCIÓN?] Se alejan, tú sabes poquito a poquito....tú sabes primero te viene con el cuento 'ah!, eso no es nada' como por no hacerte sentir mal pero con el tiempo pues tú te das cuenta que pues se alejaron (Kathy, 21 años). 
- gracias a Dios aceptó mi condición y esa experiencia me ayudó también a aceptarme, a aceptar mi condición y me ayudó a mejorar mi autoestima (Mauricio, 19 años).

- al principio él lo tomó en shock porque él tuvo que vivir con los papás que eran, como te explico, drogadictos y cuando yo le digo eso se quedó como wow. Y nada, ese día yo le dije, pues mira vamos a dejarlo aquí, porque estaba ya... este él se fue, pero regresó pero como yo me había acostado, me escribió una cartita, pero no me la entregó, como que estaba desto, no le voy a entregar nada, pero la tiró, por ahí, como yo estaba por ahí pues la cogí, la había encontrao y llamó para ver cómo estaba y pues al otro día volvimos porque dijo que no le importaba (Emma, 20 años).

- ...se quedaron en shock pero no, no fue algo que juzgaran, se quedaron como que 'en serio, no lo puedo creer' y que se yo, pero siempre estuvieron ahí. Nunca dijeron no te voy a dejar sola, no. [Y, ¿TODAVIA SIGUEN SIENDO TUS AMIGOS?] Sí. [Y, ¿POR QUÉ DECIDISTE DECIRLE?] Porque siempre han estado conmigo y ellos me cuentan todas sus cosas y yo pues, no, no me quería sentir que estuviera escondiendo algo. Siempre que yo doy mi amistad tiene que ser sincera si no, no (Victoria, 18 años). 


\section{THIRD MANUSCRIPT}

“That’s True Love:” Lived Experiences of Puerto Rican Perinatally HIV-Infected Youth within Their Families Context

Georgina Silva-Suárez, ${ }_{1}$ Elena Bastida, ${ }_{1}$ Silvia E. Rabionet, ${ }_{2,3}$ Consuelo Beck-Sagué, 1 Mario De La Rosa, ${ }_{1}$ and Irma Febo, 3

${ }_{1}$ Florida International University, Miami, FL, USA

${ }_{2}$ Nova Southeastern University, Ft. Lauderdale, FL, USA

${ }_{3}$ University of Puerto Rico, Medical Sciences Campus

\section{Corresponding Author:}

Georgina Silva-Suárez, MPHE, PhDc, Florida International University, Robert Stempel College of Public Health and Social Work, Miami, FL, 33199,USA

Email: gsilv010@fiu.edu

\section{Acknowledgments}

I express my sincere gratitude to my dissertation committee for their guidance and dedication: Dr. Elena Bastida, Dr. Consuelo Beck-Sagué, Dr. H. Virginia McCoy, Dr. Mario De la Rosa and Dr. Silvia Rabionet. I would like to thank Dr. Carmen Zorrilla, Dr. Irma Febo, the staff of the University of Puerto Rico (UPR) Pediatric HIV/AIDS Research Program and CEMI and the Puerto Rico Mentoring Institute for HIV and Mental Health Research for supporting this study. Also, I would like to thank Dr. Annette B. Ramírez de Arellano, and my research assistant, Ana Carolina Arboleda, for their invaluable contributions to the study. I thank Florida International University, Graduate School for awarding me a Dissertation Year Fellowship. 


\section{Declaration of Conflicting Interests}

The authors declare no potential conflicts of interest with respect to the research, authorship, and/or publication of this article.

\section{Funding}

This research study was funded by the National Institute of Mental Health (NIMH) through the Puerto Rico Mentoring Institute for HIV and Mental Health Research (grant \# 1R25MH083617) and Florida International University, Dissertation Year Fellowship

\section{Biographical Information}

Georgina Silva-Suárez, MPHE, PhDc is a health educator and graduate student at Florida International University, Robert Stempel College of Public Health and Social Work

Elena Bastida, $\mathrm{PhD}$, is a professor in the Department of Health Promotion and Disease Prevention at the Robert Stempel College of Public Health and Social Work at Florida International University

Silvia E. Rabionet, EdD, is an associate professor in the College of Pharmacy at Nova Southeastern and in the School of Public Health at the University of Puerto Rico, Medical Sciences Campus

Consuelo Beck-Sagué, MD, is an assistant professor in the Department of Health Promotion and Disease Prevention at the Robert Stempel College of Public Health and Social Work at Florida International University

Mario De La Rosa, $\mathrm{PhD}$, is a professor in the Department of Social Work at the Robert Stempel College of Public Health and Social Work at Florida International University 
Irma Febo, MD, is an associate professor in the Department of Pediatrics at the School of Medicine of the University of Puerto Rico, Medical Sciences Campus. She is the director of the UPR Pediatric HIV/AIDS Research Program.

\begin{abstract}
This study used interpretative phenomenological analysis to explore the life experiences of perinatally HIV-Infected (pHIV-I) youth in Puerto Rico within a family context. It focused on the evolving nature of the family and the array of situations experienced by these youths and their families. Twenty in-depth interviews were conducted and audio-recorded; these included questions on participants’ families, family structure, family management of HIV, and perceptions of their parents. Study participants considered their family to be essential and dynamic players in their lives and treatment, and as a source of love and support. In contrast, they also reported being stigmatized and discriminated against by members of their own family. Not surprisingly, the burden of losing one or both parents at a young age was considered more difficult to handle than having HIV. Among those losing their parents, most ended up living with other family members. This became a challenging situation for the caregivers, especially for grandparents who were dealing with their own grief. Study participants described their health care providers as part of their extended families and choose to keep in touch with them as they transition to adult care. Despite the changes and challenges that families of pHIV-I youth must endure, most participants expressed a desire to have children at some point in their lives. Findings presented here suggest that services targeted to this population need to stress social support, incorporate family members into the medical process, provide their patients special guidance and support while
\end{abstract}


transitioning to adult care, and make available to their patients the latest information regarding HIV prevention, treatment, and reproductive decisions.

Key words: Adolescents; Puerto Rico; HIV perinatally infected; interpretative phenomenological analysis; Family

\section{Introduction}

Over time, the HIV epidemic has evolved with similar characteristics worldwide. Whether a country is developed or developing, the disease "disproportionately affects the poorest parts of the world” (Lamorde et al., 2012, p.1; UNAIDS, 2011; Hazra, Siberry, \& Mofenson, 2010; Mitchell \& Linsk, 2004). In the wealthiest countries, it primarily impacts the poorest areas and most socially marginalized people, including those who are homeless, substance users, and individuals from racial, sexual, and ethnic minorities (Mitchell \& Linsk, 2004; Lee \& Johann-Liang, 1999). In the United States, the highest prevalence of pediatric HIV infection is found in the poorest urban areas within ethnic minorities' enclaves, which have historically suffered discrimination and racism (Wiener, Mellins, Marhefka, \& Battles, 2007). Most of the striking racial and ethnic disparities seen in HIV prevalence in the urban US population disappear when controlling for spatial distribution in low income neighborhood, where over $20 \%$ of residents live below the poverty level (Denning \& DiNenno, 2010).

The burden of HIV affects not only infected patients but also their families and caregivers (Gomez, Fernández, Otero, Miranda, \& Hunter, 2000; Shang, 2009; Schuster et al., 2000). Families of HIV-infected patients encounter stigma and social discrimination linked to the disease (Ji, Li, Lin, \& Sun, 2007; Iwelunmor, Airhihenbuwa, Okoror, Brown, \& Belue, 2006). In some cases, the disease label may be applied to an 
entire family; in a village in Nigeria, for example, when a person acquires HIV infection, the villagers call the whole family an "AIDS family" (Alubo et al, 2002 as cited in Li et al., 2006). Children of families affected by HIV struggle to understand why they are mistreated (Ji et al, 2010).

HIV-infected individuals and their families also face financial problems in addition to confronting the burdens of the disease. For example, in the Caribbean and worldwide, employers may test prospective and current employees, often without advising them that they are being tested or informing them of their results; this information is used to exclude HIV-infected persons from employment (Human Right Watch, 2004). In China, employees reported to be fired because they tested HIV positive (Cao et al, 2005, as cited in Li et al., 2006). Moreover, the disease also has financial implications for those uninfected family members expected to provide support to the affected. Worldwide, families not only help the affected individual to cope with the disease but also provide financial and medical assistance and psychological support (Li et al., 2006).

Family support is crucial for people living with HIV and can be critical to decision-making related to treatment-seeking and other situations (Li et al., 2006). Among adolescents living with HIV, family members and caregivers may be the ones who remind them to take their medication (Michaud et al., 2010). Among pHIV-I youth, family members assumed responsibility for their treatment when they were young children (Hazra et al., 2010), and this support often continues into adolescence. Among Latinos, close and supportive family relationships are important throughout the life span (Díaz, 1998). Maintaining a close relationship with family and 
viewing the family as a source of emotional and material support is known as familismo (for example see, Marín, 1989). Puerto Ricans value their social relationships and consider family and friends as a source of support in their life trajectories (Varas-Díaz, Serrano-García, \& Toro-Alfonso, 2005).

This article explores the life experiences of Puerto Rican pHIV-I youth within a family context, focusing on the evolving nature of families and the diverse challenges faced by these youth and their kin. Participants' narratives of their lived experiences enable us to examine diverse periods in their lives. In addition, these accounts should facilitate understanding the meanings and constructions they assign to "family." Through their narrated experiences, we learn what they value the most, who they consider family, how they make sense of their life situation following a devastating blow in their lives, feelings about their family, and desires to start a family of their own.

\section{Methods}

This study used interpretative phenomenological analysis (IPA), a qualitative framework that seeks to explore how persons make sense of their everyday life experiences (Smith, Flowers, \& Larkin, 2009). Phenomenological research seeks to examine an experience or phenomenon "the way it occurs and in its own terms” (Smith et al., 2009, p. 12).

The IPA approach allowed to gather the vivid recall of participants lived experience within their family context, in addition to the meaning they ascribed to those experiences. However, it is recognized that what they believe to "vividly recall” has been altered by the passing of time and repeatedly transformed in their memory recollections of the family interactions, transitions and other life events involving their families. And 
thus this "vivid recall" is at best a reconstruction of the experience in question. For purposes of the material presented here, the exact details of the family interaction or event is of little importance, however, the reconstruction of these interactions are very much at the center of the discussion. It is not the accuracy of the past interaction or event itself that is of importance here, but how this experience and/or event, however recalled, reconstructed or transformed many times over, throughout the years, has shaped and continues to shape the current unfolding of their lives and their interactions with their families.

\section{Sample Selection}

Purposeful sampling was used to recruit study participants. This sampling method seeks to select information-rich cases to study in depth (Patton, 1990). Powerful or rich cases are those "from which one can learn a great deal about issues of central importance to the purpose of the research" (Patton, 1990, p.169). The in-depth interview was selected as the method most suitable to collect participants' life experiences. Eligibility requirements included: being current or former patients of the UPR Pediatric HIV/AIDS Research Program; pHIV-I; aged 18-30 years, having knowledge of their HIV status; and willingness to share their life experiences.

\section{Recruitment}

The UPR Pediatric HIV/AIDS Research Program’s staff physicians, nurses, and/or social workers determined whether or not patients met the inclusion criteria when they attended the clinic for their routine visits. When potential participants met the inclusion criteria, UPR Pediatric HIV/AIDS Research Program staff invited them and their parent or guardian, when appropriate (i.e., when the potential participant was less 
than 21 years old), to participate in the research study. After participants and their parents agreed to the interview, they were contacted by telephone by the first author, who explained the purpose of the study and gauged their willingness to participate in an interview to explore their life experiences as pHIV-I youth living with HIV.

Questions or concerns were clarified during the telephone conversation, and an interview appointment was scheduled. Participants and their parents or guardian (when needed) gave written informed consent.

\section{Interview Guide}

A set of open-ended questions was developed (See appendix A for the interview guide). These addressed the main goal and research question of the study, which was to examine how pHIV-I youth describe the impact of HIV in their lives, placing special emphasis on their families of orientation, on their decision to start their own families (families of procreation) and overall on the quality of family interaction and their perceptions and feelings. In keeping with the IPA framework, the questions sought to elicit both the respondents' experience with certain phenomena and how they interpreted these phenomena. A list of open-ended questions was then subdivided into three major thematic areas: personal, social, and medical.

The interview guide was assessed by experts on perinatal HIV infection; these included a physician, a social worker, and a public health specialist. The question guide was piloted with a potential participant, who reported feeling comfortable during the interview, and thought that the questions were very appropriate and pertinent for pHIV-I youth in Puerto Rico. No changes were made after conducting the pilot. Throughout the 
process, we sought to learn how participants made sense of their experiences in their own words.

The Institutional Review Boards (IRBs) of the Florida International University and the University of Puerto Rico Medical Sciences Campus evaluated and approved the study protocol.

\section{Data Collection}

Twenty pHIV-I women and men between the ages of 18 to 30 years were recruited and interviewed. The interview lasted 45 to 90 minutes. Interviews were conducted in a non-judgmental, respectful environment at the Maternal Infant Study Center (CEMI, for its Spanish acronym), a sister clinic to the UPR Pediatric HIV/AIDS Research Program that also provides services to people living with HIV. All interviews were conducted in Spanish, the native language of both study participants and the first author. After interview completion, each participant received a monetary incentive to cover transportation and other expenses associated with study participation.

All interviews were audio recorded, then transcribed by the first author.

Transcripts were sanitized by removing any comments that may have compromised confidentiality. A graduate research assistant, immersed in Puerto Rican culture and proficient in English and Spanish, translated all interviews. ${ }^{5}$ It is noted, however, that the original Spanish text was used in conducting the qualitative analysis presented here; thus avoiding a third level of text interpretation, as indicated in qualitative procedures.

\footnotetext{
${ }^{5}$ Four of the authors are native Spanish speakers. Each independently read and selected Spanish transcripts and cross validated the English translation.
} 


\section{Data Analysis}

Transcripts were examined individually. Following the steps proposed by Smith et al. (2009), the researchers read and re-read each of the transcripts establishing the participant as the focus of analysis. Transcripts were examined in an open-minded, systematic, and exploratory manner. Initial observations were recorded along the margins of each transcript. In addition to the first author, transcripts were read by at least two other members of the research team and contributors to this paper. Passages from the interviews were then discussed with other team members in relation to situation and meaning construction, as suggested by the IPA approach.

The first exploratory stage of the analysis identified approximately 40 themes. These were narrowed down or consolidated according to the following criteria: (1) their recurrence within and across cases (how often they were mentioned); (2) their relevance to care and treatment; (3) the relationship across themes.

To understand the meaning that participants constructed when talking and introspectively examining their family experiences and interactions, twelve interrelated and connected themes were selected, including: parenting, caregivers, social support, family support, life challenges, having a living biological mother, absence of resentment, fear of rejection, mental health, relationship with healthcare providers, feeling of anger and hatred, and stigma and discrimination.

Figure 1 presents a diagram indicating how these eleven themes are not only interconnected, but fall within the four broader dimensions that gradually emerged from the narratives participants constructed when attempting to relate their lived experience 
within their family context. Each of these four dimensions is used below in organizing the data analysis and in illustrating the findings.

Figure 1. Patterns and Connections Among Themes That Emerged During Phenomenological Analysis

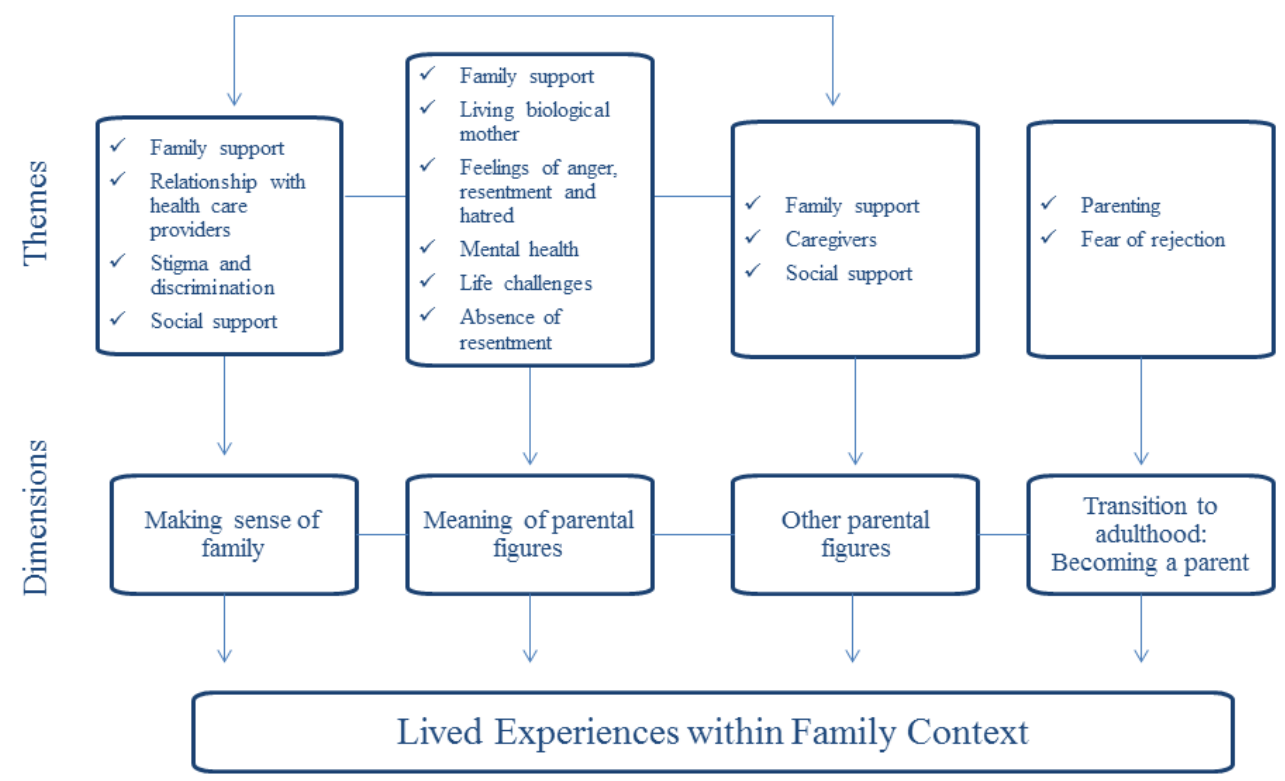

\section{Multiple Coding (Inter-Rater Reliability)}

In order to confirm the themes that emerged, 10 of 20 interview transcripts were assessed by two professionals, one in the area of human rights and the other in public health. Both identified major themes from the same 10 transcripts. The emerging themes were then cross-checked by each professional. When this procedure revealed discrepancies in topics, the coders clarified and discussed other possible interpretations, refined or created a new code or theme. NVIVO 10 (QSR International, Burlington, and 2014 USA) qualitative analysis software was used to facilitate the systematic processing of the information generated by in-depth interviews. 


\section{Findings}

\section{Demographic Characteristics of the Study Population}

Of the 20 study participants, eight were male and twelve were female.

Participants ranged in age from 18-29 years (mean age=22 years). Eighteen had

completed high school and two had completed middle school. Only one study participant was married at the time of the interview; sixteen were single and three were cohabitating (see Table 1).

Table 1

Sample Demographic Characteristics by Gender

\begin{tabular}{ccc}
\hline Characteristics & Male & Female \\
\hline 8 & 12
\end{tabular}

Age distribution

18-19

20-21

32

22-23

24

24-25

1

4

26-30

1

1

1

1

Highest Academic Degree Completed

Middle School

$0 \quad 2$

High School

8

10

Marital Status

Single

6

10

Married

$1 \quad 0$

Cohabitating

1

0

Employed

Yes

No

3

6

Studying

Yes

No 


\section{Making Sense of Family}

While exploring the life experiences of pHIV-I youth, family emerged as a central presence and foundation in their lives. Four broad dimensions were particularly highlighted from participants' narrated life experience related to family: (1) making sense of family; (2) the meaning of parental figure; (3) the roles of other parental figures; and (4) the transition to adulthood: becoming a parent. These topics were recurring themes in participants' interpretation of their life experiences related to their families. Fragments of participants' narratives were selected to support each of the themes; informants were given fictional names to protect their identities (see appendix B for participants' quotes in Spanish).

Meaning of family. When study participants spoke about the most significant people in their lives, all of them agreed that these were members of their family. Family meant everything to them, as expressed by Emma a 20-year old student:

My life. My family is my everything. Family is... (silence) everything for me, like a little part of you.

Family is where they find love, trust and support. Family members are the people who have been with them during their most difficult situations in life, and they were therefore very thankful for the solidarity they received from family members. Mauricio, a 19-year old student, agreed with this meaning and shared what family meant to him: Well, for me family is a support group; you know, it's essential for every human being to have that warmth, that affection, because they're the people that represent security for the human being. They symbolize unity, you know, and it's something, really very beautiful when the family is united, always keeping in 
contact, supporting one another. And that's really how it should be in a nuclear family.

The "dark side" of family: Even though most study participants said that family was the institution in which they found love, trust, and support, family experiences varied. Some study participants recall experiencing rejection from specific family members. Marina remembers how one of her aunts and cousins were loving and affectionate with her siblings who did not have HIV, but not with her.

Well, my family on my mother's side, [puff] super well. My family from my father's side, I have already seen there the ignorance and I have some cousins that aren't very... I am very clingy and very touchy-feely, and a hug-giver and they you know... [and it's] because of that, because they're crazy about my sisters. But since I was little, I have always been the one that's excluded, at least with them and their mom. Their mom was always... you know. But anyways, they don't hug too much, no... [it's] ignorance, but I have already seen that those on my father's side are more likely to (gesture of rejection, aauuhh) than "love". It's funny because his brother, he had it [HIV] as well [referring to his father].

Luz also recalls how, when she was little, one of her great-aunts seemed to fear “contamination” whenever she visited their home.

My grandmother's sister, whom we call "aunt," would not eat our food or drink from a glass whenever she came to visit us.

Kathy, a 21-year old self-employed woman, was visibly affected as she reconstructed how her sister told everyone about her diagnosis, disregarding her will or her feelings about the matter. 
... Because she does not have it, she told others, because we have never gotten along well. [HAVE YOU TOLD HER HOW YOU FEEL?] The one who assumed that role, of talking to her, was mom, but she [her sister] still sort of treated her even more disrespectfully.

Healthcare providers as family. When study participants talked about their health care providers, they described them as part of their extended families. Most respondents agree that those who have been taking care of them were also their family. Even though some recognized that medical visits and exams could be tiring, they also acknowledged the love and support they had received from their healthcare providers. Study participants said that not only did they help and support them, but also supported their family. When reconstructing her medical experience, Marina said:

My experience (she laughs) they are my second family. I have been here all my life and honestly... [ ] they are my second family and they are the kind of people who have taken my family, also my grandparents you know, and my experience to heart, you know, and have treated me well (she laughs).

The majority of them agreed that the clinical care they received has been good, but what they most appreciate is their providers' affection and sincere dedication towards their wellness. Arturo shared his experiences at the UPR Pediatric HIV/AIDS Research Program and his perception of what he thinks is most important in clinical care:

Well, very good, they are part of my family already. They all saw me at birth; they have seen how I have grown. [ ] Their quality, the human quality that they show, they are very special to me. Very special to me... that is what I will miss the most, because I know that the medicine is there and any doctor can prescribe it. But 
it's not only a medical issue, it's that they care about me, they look after me... That is worth more than anything else.

Those already transitioned into adult care, acknowledged that adult care is very far from what they were used to in pediatric care. This is Esteban's experience: [ ] the fact is that never again have I been treated like at [UPR Pediatric HIV/AIDS Research Program]. They have come to be my family; they are my mother, my father, everyone is there, you know. I was scolded at times, but it was all, everything; very, very familiar. And when I go elsewhere to get care, it is not the same.

They were thankful to have had great care during their developmental years, helping them cope with their life challenges. Mauricio narrated his experiences at the UPR Pediatric HIV/AIDS Research Program:

Well, because the doctors here, in project [UPR Pediatric HIV/AIDS Research Program] they've provided me with great psychologists, great doctors who have helped me, you know, accept my condition. And always, since I was little, even when they have not told me what my condition was, they taught me to value myself, to not feel less than anyone. They helped me a lot to be a confident person. They taught me to be a confident person and so all those motivational words from the psychologists, from the doctors, well my family, also church groups. [ ] Actually I don't have any complaints about anyone, because aside from being health professionals, from being nurses or doctors, they've also been a helping hand, they've been a helping hand, they've supported me and they've been more like a part of my family for me. They're like family to me. 


\section{Meaning of Parental Figures}

Even though study participants said that family meant everything to them, the fact is that most families have experienced very difficult times. Losing family members, dealing with a potentially fatal illness, and taking care of a newborn, are only some of the situations the families of pHIV-I youths have had to cope with. Five study participants said that they had lost both parents due to HIV; another eight had lost at least one parent. Participants characterized the burden of losing one or both parents at a young age as a heavier weight than having HIV. This early loss irrevocably became the catalyst for numerous life challenges pHIV-I youths have had to address.

Mother figure. Six study participants considered themselves blessed because their parents are alive and they know many other perinatally HIV-infected youth who have not been as fortunate; several referred to their mothers as their "life.” All of them said that they love their mothers very much; they are proud of them and see them as role models and "fighters." In addition, they recognized that sharing the same health condition and having an ally in their life journey made it more bearable. This is Emma's experience, she considers herself blessed to have her mother around:

My mom, that was here (her laugh), well she always... she's my life, I love her, she's always been there with me, always. [I feel] lucky to have her with me. To have her healthy. [DO YOU THINK HAVING HER AS A PARTNER MAKES IT EASIER?] Yes, she's always talking to me about whatever new things there are. She's the one who says: "Emma, the pills, the pills" because every time she takes them she also sets them out for me. I am proud of her, because she really has overcome a lot, she's a fighter. 
Carla, a 23-year old professional, also considers herself fortunate to have her mother alive. She sees her mom as an example to follow and a source of support. My mom [ ] is my main model, a hard working woman, always. Well today I am 23 and she is still GI with the medications, the appointments; you see, we come to the appointments together. She's always come to my appointments at [UPR Pediatric HIV/AIDS Research Program] and she really is my biggest [role] model. [I feel] Blessed. Imagine that, even though we share, how do I say, the same condition, we are always there holding each other's hand. Really, thanking God, because even though we have the condition, we are well. And well, we pray so that things stay like that and she will be around for a long time.

When study participants talked about their fathers, their opinions and feelings varied considerably. Most spoke fondly about their mothers, but not so about their fathers. This is often linked to the fact that they see them as the source of their HIV infection.

Feelings towards their fathers. Most of the study participants' mothers were believed to have been infected by their partners --- the study participants' fathers--- with injection drug use as the fathers' route to HIV infection.

Fernanda was one participant who learned that her HIV infection indirectly resulted from of her father's drug use:

There they told me that it was that my father used drugs and infected my mother who infected me, and that was all. [AND YOUR FATHER?] Well, I don't know so much, and, well, I can't deny that I feel a lot of resentment toward him even if he's dead... but I can't forgive him. 
Some study participants said that their mothers were not necessarily aware of their fathers' HIV infection; they therefore feel resentment towards the father. Isabel shared her feelings towards her father:

At present the person I hate is my dad. Because knowing that he had it and the condition he had, he didn't care and he didn't take care of my mom. [OH, SO HE KNEW?] He knew, actually, before being with my mom; 3 or 4 women in the same area where my mom lived died because of him.

Luz, a 23-year old mother of one, expressed feelings of disgust and hatred towards her father, talking harshly about him. Other respondents said that forgiveness was not possible, because they blame their fathers for the loss of their mothers and for their own HIV infection:

When mom told me about what I had, and have, well I got upset with my father and, since then, I have never loved [him]. He is dead, he died at twentysomething [ ]. I'm glad he's dead because otherwise I would kill him.

In this situation, the patients as well as their siblings and other family members suffered the consequence. One study participant said that faith in God helped her to forgive her father for transmitting the HIV to her mother and indirectly to her. But her sister could not and cannot handle the situation, expressing hatred toward him. This is Marina’s experience:

Well, I think that even today, even if they deny it, there is resentment towards my father, because, obviously, in a way it was his fault. My sister is the one who never accepted it; still today she hates my father, she hates him and expresses it this way: "Why not him instead of my mother?” And I think that my grandmother 
always resented my father as well [ ]...there's resentment towards him, because it's his fault that she died. [ ] I had to personally forgive him, in the sense that, it is his fault. Like I said, I have values, and I say God knows what He's doing. Because of all my family, and all of my siblings, I am the only one who believes in God and has faith. And for me that isn't a coincidence: that I, who am the youngest, the one who was born with it, I believe in God and have faith. For me that isn't a coincidence.

Several participants did not show any resentment towards either parent. For example, Alonso expressed compassion and understanding, saying that he cannot blame them but the circumstances; and that he is sure that his parents loved him.

....and I don't feel bad because I just don't feel bad. It's like I say, I know that if it wasn't for her I wouldn't have gotten it because she's my mom and I know she loved me and my dad too; they loved me, you know, so I don't feel like that... I don't saddle them with blame. The circumstances are to blame, because everyone had their thing and not everyone is perfect and they made mistakes. So I can't judge them because of that, nor will I say that they're bad [...] At least they gave me life and until this day I'm pretty big and fat [both of us laugh]; I really don't feel bad about this...

Loss of parents. The ages at which study participants lost their parents ranged between one and 16 years. Regardless of the age at which they lost them, the impact on their lives was profound. While some do not want to remember them, others yearn to be able to hear their mother's voice at least once more. This is the case of Isabel, a 22-year old mother of two who also said that having HIV and overcoming the challenges and the 
burden of the disease would have been easier with her mother alive. Her interpretation of that experience is as follows:

My [ ] mother died the day of my 1st birthday. It's very, very painful, because my mom was only 26 years old when she died, a girl. And not being able to, how do I say it, not being able to have her next to me, at the time I found out about the condition, and for her to help me, hear her voice, to know how she spoke, to feel her next to me, we would have gone through the same, we would have been able to understand each other so well. And not to have been able to live those experiences, well...

The families of two study participants told them that their first birthday was celebrated in the hospital so that their mothers could participate. Because of the death of their parents, some study participants concluded that those affected with HIV can die due to this condition; it was at that moment that they started to see HIV as a something to be feared. Some study participants sought psychological assistance to help them overcome the loss of their parents. Alonso, a 20-year old participant who lost his mother at a young age, did not worry about HIV at that time, but rather found the loss of his mother devastating:

Yes, well, right, because, when I lost my mom, because of the condition, when I was 5 years old and she was 21. [ ] So that didn't affect me at that point, it wasn't about the condition itself. It was because I had lost my mom. There was a time that, that I was like traumatized, I was traumatized, but they took me to a psychiatrist, psychologists and that helped me. And, anyways, after that I moved 
on little by little. You know in part I was never like, it was like that for a brief moment; but I was able to continue my normal life.

Arturo, 22 years old and a father of two, said that losing his parents was a very dramatic experience:

The biggest shock was that my parents died and I was only 4 years old. [THEY BOTH DIED WHEN YOU WERE 4?] Yes, one in June and the other in July, [just] a month apart.

\section{Others Parental Figures}

Adoptive parents. Participants who were adopted expressed warm feelings towards their adoptive parents. They now acknowledge that taking care of an HIV infected infant was probably difficult, so they are very grateful for their adoptive parents who adopted them nevertheless. Victoria, an 18-year old student, relates how her mother adopted her even though her health condition was precarious at the time. She said that it was an act of "true love:"

That was true love, because not everyone does that, not everyone does that. And besides, I was very little, had the condition, and then I got very sick. I don't know what I had but I was close to death. And when I was born I weighed 4 pounds and I was really tiny, I was 13 ” or something like that, I was very small, really tiny. And when she saw me, well, she fell in love and adopted me. And I don't know, but after that, things got complicated and I got sick and I spent some time in the hospital.

Other study participants mentioned the difficult situations that their parents endured to protect and care for them when they were very young. Esteban, a 26-year old 
single male and one of the oldest study participants, said that he needed to go to the clinic monthly to receive a treatment for HIV infection (possibly intravenous immunoglobulin). He described how his family struggled with bad weather and transportation when taking him to the clinic for treatment:

[Referring to his adoptive parents] Yes, they do not know who my real parents are, or anything. It's as if they gave me my life and they [the adoptive parents] were there and I could see that. You know, I cannot get soaked; I am not supposed to get wet because I quickly begin to cough [ ]. And they were always there for me, they were always taking me to the hospital and... We did not have a car and it was a long way off because sometimes when we took the bus we got soaked. It is something that I really am grateful for, that they adopted me, because they have been very responsible parents.

Caregivers. Most study participants who lost their parents lived with other family members. This was a challenging situation for the caregivers. Not only did they have to deal with the HIV infection, but also with the frustration and suffering of the study participants. Oftentimes, grandparents were the ones who assumed the responsibility for their care, a particularly difficult situation. Some were still grieving their daughters or sons, while they also had to assume responsibility for their grandchildren. For some, accepting the death of their own children and discovering that their grandchildren had an HIV diagnosis were difficult and very emotional situations to absorb. Most had to resume parenting their grandchildren at a later stage in their lives. Moreover, they had to learn how to manage institutional matters, such as school 
applications and medical care in order, to obtain benefits for their grandchild. This was the situation of Marina, a 23-year old student:

Well, when I was very sick - you know, I was already [sick] at two months of agemy grandparents, who were always very close to my mother, were desperate. And when they took me to the hospital... and my grandmother was told (the diagnosis), well, she said she could not take it. She went into a depression, also because of my mother. My mother's death was something that had a strong impact on them [ ] But it was not just terrible for them [...] they did not know what to do in 1989 with a two-month old baby who was almost dying; they did not know what to do and the doctors told them "look, she is not likely to live long..." It was awful for them to accept that, and realize it, and try to live through it.

Caregivers also had to deal with rebellious acts on the part of study participants.

Fernanda, a 29-year old mother of two, said that she left her caregivers' house to pressure them to tell her the truth about her health situation.

I left my house one weekend, and when I returned, my aunt asked me what it was that I wanted, that I could not do that to them, leaving like that, that she was scared because my mom had died and when she died, I became a rebel.

Isabel shared how she started using drugs as a way to handle the difficulties she was going through, such as losing her mother, an uncle, enduring sexual molestation, and disliking her physical appearance due to the side effects of HIV medication. She later said she gave up drugs because of the suffering she was causing to her grandmother and the family who had been taking care of her since she was one year old: 
I went through drug addiction. That was another experience I went through after I found out about my condition. I began to hang out a lot with a cousin and I began to learn about pot, cigarettes, heroin, crack. [YOU TRIED ALL THAT?] I tried all that but I can't say that I got into all that because if I had, I would not be here now. I did try it, and used it at least once. And I have to tell you that I became really crazy. But I have no regrets because I think that was a process I had to go through because of what had happened. Now, what is important is to change and be different and show my children that it is wrong.

\section{Transition to Adulthood: Becoming a Parent}

Most study participants agreed that they would like to be parents someday. Some said they were too young to take that step and also acknowledged that because of their HIV status they need to be more cautious than other peers. This is Emilia's perception of becoming a mother:

It's going to be somewhat difficult, because it is not going to be a normal process. I am going to have to be more cautious than any other mother... (Emilia, 21 years old)

Kathy, a 21-year old self-employed woman, was one of the participants who would like to become a mother in the future:

I don't feel ready to have a kid now, so I will make do with having nephews. But I'd like to, though not right now.

Rodrigo, a single 21-year old participant, shared similar views, saying that he was interested in becoming a parent, but he needed to be financially and personally established before making that decision: 
(Speaking of when he would like to be a father): ...when I have a decent job, have settled down, and have a house.

Six study participants were parents at the time of the interview. All agreed that being a parent was the most wonderful thing they have experienced. This is what Luz, a 23-year old mother of one, shared about being a mother:

(Referring to the experience of being a mother): It's brutal. It's good, but it is difficult, though good.

Arturo also shares his perception of being a father:

Very satisfactory and very enriching. Very good, it really has been.

All study participants who reported being a parent said that their children as well as their partners were not HIV infected. However, some study participants feared that their children could suffer HIV stigma and discrimination as a result of having an HIVinfected parent. Isabel's fear extends well beyond this concern. She fears that if her kids are discriminated against because of her HIV infection, they will turn on her and judge or reject her because of that:

Even if they don't have it, they may be rejected because they'll think that they have it. Because there are a lot of ignorant people in this life. And [...] if they get picked on, then they'll go home and they'll start judging me, and blame me for having been treated like that, and... and having to live through that experience scares me. It scares me...

\section{Discussion}

Approaching the family from a life course perspective provides the tools to better understand the lived experiences of pHIV-I youth within their family context. The life 
course perspective allows the researcher to conceptualize the social and psychological development of the individual within the "historical forces that shape the social trajectories of family, education and work, and they in turn influence the behavior and particular lines of [their individual] development” (Elder, 1998, p.2). Using this perspective, we can explore how these forces impact the individual life experience across the lifespan (Hutchison, 2010).

The interview guide used in this study was designed to collect information regarding the meanings and reconstructions of attributed life events, trajectories, and turning points in the life of pHIV-I youth in Puerto Rico as these are embedded within the family context. We obtained information that shed light on how the family unit was affected by the HIV and AIDS diagnosis and how, in turn, they reacted to this disclosure.

Studies have found that the burden of HIV affects not only infected patients but also their families and caregivers (Gómez et al., 2000; Shang, 2009; Schuster et al., 2000). Family members are often the ones responsible for the medical care, social support, and adherence to medication of the HIV patient (Ji et al., 2010; Li et al., 2006; Richter, 2010).

The meaning that the study participants ascribe to their family is linked to how the family fulfills its members' needs. Study participants expressed that their families mean everything to them; they recognized that family members have been with them during very difficult times. As they reconstruct their life experiences within the family context and daily interactions with family members, they emphasized their appreciation for the support they have received from them. As is the case among other cultural groups, most Puerto Rican families rely on family members as the first sources of support in adverse 
situations or even when facing ordinary aspects of daily life (Varas-Díaz et al., 2005).

Most study participants agreed that when they are among family members, they can be themselves without being judged or discriminated. Their immediate family provided very special support and unconditional love; it is also where their "secret" is known and respectfully safeguarded.

Family members usually know valuable information about each other; this information can be used to support and help them through life. However, on occasions this information can become a source of discomfort and suffering. Family interactions can be tinged with stigma (Varas-Díaz et al., 2005). One study conducted in Puerto Rico found stigma toward HIV positive individuals among family members (Varas-Díaz, Serrano-García, \& Toro-Alfonso, 2004). Study participants shared their experiences of discrimination and breaches of confidentiality within their families. Participants reconstructed discriminatory experiences received from family members such as, avoidance in sharing utensils, while others assured their physical distance and suffered from lack of affection from their relatives. One female participant said that her own sister had disclosed her HIV status outside of the family. This participant was greatly affected by this action; however, she is one of a few who considered herself to be blessed because her mother is alive.

Study participants reported receiving support and love from others sources, such their healthcare providers, which they refer to and consider an extension of family. In a study conducted in South Africa, Iwelunmor et al. (2006) found that HIV/AIDS couselors and health-care providers were considered family members due to the support they provided to their patients. Others research studies (Michaud et al., 2010; Valenzuela 
et al., 2011; Vijayan, Benin, Wagner, Romano, \& Andiman, 2009) have shown that study participants attach much value to their relationship with their healthcare providers. In agreement with the aforementioned research, most study participants expressed how they and their families received support, caring, affection, medical care, and love from their health professionals during their journey with HIV. These experiences led participants to consider their professional caregivers as "family." These professionals are the one who accompanied them throughout the different stages of their lives and have seen them grow and develop. Study participants expressed gratitude to these professionals and credited them for helping them to accept their HIV status and feel empowered and confident about themselves. Their healthcare providers have become a key source of social support for them.

Mothers are crucial support figures for study participants. Those whose mothers are living indicated being thankful and feeling "blessed" because they know multiple pHIV-I peers who have lost one or both parents. These participants consider their mothers "fighters" and refer to them as role models to emulate. They observed how their mothers deal and manage their own HIV-infection and also how they help them to cope with theirs. In a sense the mother who shares her diagnosis becomes not only a role model but also a "socializing agent" who directly transmits to her child the knowledge and behaviors necessary in responding to this condition.

In contrast, participants had a different, negative perception of their fathers. The life experiences of study participants within their families are context-dependent; their perceptions of HIV are also contingent on their environment. All study participants were born within the first decade of the HIV/AIDS epidemic (1983-1994); their views on their 
fathers could, therefore, be linked to that particular historical period. Some study participants expressed that their fathers' HIV infection was due to intravenous drug use. Some also said that their fathers were aware of their own health situation and kept it from their mothers. At the beginning of the epidemic, HIV/AIDS was associated with particular groups in society that were stigmatized prior to the epidemic such as homosexuals, intravenous drug users, and commercial sex workers (Varas-Díaz et al., 2004). These negative societal appraisals could explain why study participants talked about their mothers in complimentary terms and spoke unfavorably about their fathers. Most blamed the fathers for their mothers' HIV infection. Thus, they portrayed their mothers as unwitting victims while their fathers received few if any favorable mention. This finding supports prior research. A study by Kennedy (2010), found that, when children learned about their mothers' HIV infection, their reactions varied from manifestations of emotional support and closeness to denial and anger. In that same study, one participant expressed anger toward his father, the source of his mother's HIV infection.

Some study participants reported the loss of their mother or father due to HIV. To them this represented a major life event and transition since they were orphaned at the time; while it also became a turning point for the entire family. Perinatally HIV-infected youth in this study expressed that one of the most difficult challenges they had faced in life was the loss of one or both parents due to HIV infection. For orphaned participants, HIV infection became a secondary challenge. They reconstructed their experiences with depression after loss of their mothers; in some cases psychological help was needed to help them overcome the devastating experience. 
Losing one of their family members represented a major disruption in the family. Not only did it have an impact on the participant, but the entire family unit was disrupted. When an HIV parent dies, the family may assume responsibility of raising the children of the deceased (Brown \& Lourie, 2000; Blasini et al., 2004; Mathambo \& Gibbs, 2009). This situation is difficult not only for the children but also for the family, since they now must face the burden and stress of caregiving (Li et al., 2006). As study participants reported, most of their family members struggled in adapting to their new life situation.

For some study participants, achieving stability and learning to live without their parents became a struggle. Some spoke of their rebellion at that point in time; others began using illicit drugs to cope with their life situation. As noted by most study participants, caregivers had to address their immediate emotional needs while also learning to monitor their care, medical visits, and their schooling. Study participants observed that their healthcare providers were a source of support for their families in this process. Healthcare providers and caregivers were key in helping the family to adapt and become stable.

Participants acknowledged that their parents and caregivers had to deal with much more than just the HIV infection. One emerging situation was coping with the children's loss of their parents. On losing their parents, these children concluded that HIV is a horrific illness that can rob them of their lives as it did their parents' lives. Participants acknowledged that it was a difficult situation for them as well as for their caregivers. The latter, as study participants narrated and reconstructed their interactions with caregivers, were grieving because of the loss of their sons or daughters, while also they noted that they had to deal with a child who had just lost one or both parents due to the same health 
condition. They understood this as a process that took time, but eventually, the family managed to regain a new balance that enabled it to cope with the life event that had shaken its foundation.

Study participants who were adopted said that they felt blessed, describing their adoption as an "act of true love." At a disruptive moment in their infancy, adoption gave these participants an opportunity to become part of a family unit where they found balance and harmony. They expressed being thankful to their adoptive parents for the opportunity to be raised within a family and expressed much admiration for them.

Although study participants have suffered the impact of diverse challenges, their life course has continued to evolve. One of the most common and expected transition to adult life is becoming a parent. This is the case for pHIV-I youth as well. According to some study participants, one of their major life milestones was becoming a parent. They said that being a parent is one of the best things that had happened in their lives, and they expressed gratitude for having HIV negative children. Childbearing was considered a defining moment in the lives of study participants; they constructed it as a new beginning in which they were given the opportunity and gift to create a family of their own.

\section{Conclusion and Implications}

Study participants experienced several devastating situations throughout their lives. Losing one or both parents due to HIV infection was one of the most difficult experiences to bear. Based on their reconstructed experiences of the conditions surrounding this event, the support they received from their family, healthcare providers and, in some situations, mental health professionals, was essential to overcoming their grief and helped them to cope with their loss. They also demonstrated great sensitivity 
toward their health condition and the implications of having HIV. Those with living mothers consider themselves blessed to have a companion in their HIV journey.

Adopted study participants gave meaning to the act of being adopted by defining it as an "act of true love" and characterized their adoptive parents as responsible and caring individuals. They also acknowledged that their adoptive parents assumed a heavy burden in deciding to adopt them.

All treasured the health care received at the UPR Pediatric HIV/AIDS Research Program and considered the staff as family. Through their narratives they revealed that the support they and their families received from these health professionals was essential not only to them but also to their families. Indeed, participants extended the concept of "family" to include these valued individuals. In their narratives, time and again, they reiterated that staff members far exceeded their professional duties and helped them and their families to cope with the implications of HIV beyond the medical context. Because of this tight bonding with their healthcare providers, most study participants agreed on their desire to receive adult healthcare comparable to the one they received in the pediatric unit (e.g. UPR Pediatric HIV/AIDS Research Program).

Findings of this study provide important information for the planning and development of medical and health services targeted to this population. As observed by study participants during their interviews, care should include continuing social support, incorporating of family members in the medical process, provision of special guidance and support while transitioning to adult care, and latest information regarding HIV prevention and treatment. These needs are clearly not addressed within typical adult clinical services that involve only the patient while rarely engaging his/her partner, and 
almost never, parents, caregivers or former healthcare providers. However, this is not the case for participants who transition to $\mathrm{CEMI}^{6}$.

Based on the reconstruction of participants lived experiences within the family context, some areas have been identified that need to be considered when dealing with this particular population. Notable, among these is the hatred some study participants harbor toward their fathers. The desirability of exploring a more balanced, mature understanding of their fathers’ behaviors is a significant unmet need in the highly supportive care that these youth have received. The perspective that study participants have towards their mothers vs. their fathers and the effect of these opinions on their lives, should be further investigated. A study conducted by Borchert \& Rickabaugh (1995) found that mode of HIV transmission is a determinant factor that influences others' perception of “personal control, positive affect, and willingness to help people with AIDS” (p. 664). Perception of individuals who acquired HIV through intravenous drug use was associated with less positive affect and less willingness to help (Borchert \& Rickabaugh, 1995). Drug use is a complex social problem that in most cases affects the family system. A study conducted among incarcerated substance users in Georgia found that fathers were not an integral part in the lives of this population; most expressed anger and sadness for the fathers’ lack of involvement in their lives (Johnson \& Hull, 2009). In addition, those incarcerated men who were fathers were not able to make a connection between their feelings towards their fathers and the possible pain they were causing to their own children, when they were almost replicating their father's behaviors (Johnson

\footnotetext{
${ }^{6}$ CEMI is the Spanish acronym for Maternal Infant Study Center. CEMI is a sister clinic to UPR Pediatric HIV/AIDS Research Program that also provides services to people living with HIV. It is part of the University of Puerto Rico and it is located on the Medical Sciences Campus, next to the Pediatric Hospital in which most UPR Pediatric HIV/AIDS Research Program participants receive their health services.
} 
\& Hull, 2009). It would be worthwhile to study pHIV-I youths' perceptions about their parents more deeply to better understand what influences their perceptions and to ascertain if substance use is a determinant factor in their perceptions.

A second area that was identified and found important to address is reproductive counseling and decision-making regarding family procreation. Six study participants expressed being parents at the time of the interview; however, none mentioned family planning, strategies for deferring or planning future pregnancies while exploring precautions to protect their partners. In the current study, only one study participant mentioned her intention for her and her future partner to be informed regarding reproductive alternatives. Participants also expressed a need to be better informed regarding new advances for HIV prevention such as pre-exposure prophylaxis (PrEP). Even when not placing HIV at the center of their lives, they acknowledged a need for education and information about their health condition as an important aspect of their wellbeing and quality of life.

Currently, study participants are going through a major transition from pediatric care to adult care. When speaking of this situation in the context of their family situations and interactions, all emphasized that this transition would benefit if the adult care were to follow the UPR Pediatric HIV/AIDS Research Program's model. All also reiterated that whatever model is developed by adult treatment clinics, these need to be comprehensive and incorporate their families into the treatment plan. Time and again their narratives emphasized their desire for a holistic approach that incorporates their families in all aspects of treatment. In their narratives there is a wistful, sentimental characterization of the UPR Pediatric HIV/AIDS Research Program's clinical services that might reflect in 
part a nostalgic recollection of the pediatric setting, while anticipating or recalling the less-supportive climate of the adult setting.

The narratives of the life experiences of pHIV-I youth gathered in this study suggest an urgent need for comprehensive health services for this population. Some study participants acknowledged that they needed psychological help to overcome and understand some of the difficult situations they encountered at some point in their lives in addition to their medical services. Also, their narratives reveal that the love and support they receive from their family, friends, and health care providers help them overcome their life challenges. They expect adult health care to not only prepare them to face challenges relevant to their HIV condition but also to help them when other challenges emerge, for example, reproductive decisions. 


\section{References}

Blasini, I., Chantry, C., Cruz, C., Ortíz, L., Salabarría, I., Scalley, N., . . D Díaz, C. (2004). Disclosure model for pediatric patients living with HIV in Puerto Rico: Design, implementation, and evaluation. Developmental and Behavioral Pediatrics, 25, 181-189.

Borchert, J., \& Rickabaugh, C. A. (1995). When illness is perceived as controllable: The effects of gender and mode of transmission on AIDS-related stigma. Sex Roles, 33(9-10), 657-668.

Brown, L., \& Lourie, K. J. (2000). Children and adolescents living with HIV and AIDS: A review. J Child Psychol and Psychiat, 41(1), 81-96.

Denning, P., \& DiNenno, E. (2010). Communities in crisis: Is there a generalized HIV epidemic in impoverished urban areas of the United States? International AIDS Conference, 21

Díaz, R. (1998). Latino gay men and HIV: Culture, sexuality, and risk behavior. New York: Routledge.

Elder, G. H. (1998, Feb). The life course as developmental theory. Child Development, 69(1), 1-12. Retrieved April 2014, from http://www.jstor.org/stable/1132065

Gómez, M. A., Fernández, D. M., Otero, J. F., Miranda, S., \& Hunter, R. (2000). The shape of the HIV/AIDS epidemic in Puerto Rico. Pan Am J Public Health, 7(6), 377-383.

Hazra, R., Siberry, G. K., \& Mofenson, L. M. (2010). Growing up with HIV: Children, adolescents, and young aduls with perinatally acquired HIV infection. The Annual Review of Medicine, 61, 169-185.

Human Rights Watch. (2004). A test of inequality: Discrimination against women living with HIV in the Dominican Republic . Retrieved, January 28, 2014., Retrieved from http://www.hrw.org/sites/default/files/reports/dr0704.pdf

Hutchison, E. D. (2010). A life course perspective. In E. D. Hutchison, Dimensions of human behavior: The changing life course (pp. 1-38). Thousand Oaks , California: SAGE Publications.

Iwelunmor, J., Airhihenbuwa, C., Okoror, T., Brown, D., \& Belue, R. (2006). Family Systems and HIV/AIDS in South Africa. Int Q Community Health Educ, 27(4), 321-335. doi:10.2190/IQ.27.4.d.

Ji, G., Li, L., Lin, C., \& Sun, S. (2007). The impact of HIV/AIDS on families and children-A study in China. AIDS London, England, 21(8), S157. doi:10.1097/01.aids.0000304712.87164.42 
Johnson, S., \& Hull, H. (2009). Fathering Capacity of Incarcerated Substance Users. The Source, 19(1), 11-13. Retrieved from

http://aia.berkeley.edu/media/pdf/TheSourceSpring09.pdf

Kennedy, D. P. (2010). Parents' disclosure of their HIV infection to their children in the context of the family. AIDS and Behavior, 14(5), 1095-1105.

Lamorde, M., Byakika-Kibwika, P., Boffito, M., Nabukeera, L., Mayito, J., OgwalOkeng, J., . . . Merry, C. (2012). Steady-state pharmacokinetics of lopinavir plus ritonavir when administered under different meal conditions in HIV-infected Ugandan adults . Journal of Acquired Immune Deficiency Syndromes, 60(3), 1-8. doi:10.1097/QAI.0b013e3182567a35

Lappin, J. (1988). Family Therapy: A Structural Approach. In R. A. Dorfman, Paradigms of clinical social work (Vol. 1) (pp. 220-252). Psychology Press.

Lee, C.-L., \& Johann-Liang, R. (1999). Disclosure of the Diagnosis of HIV/AIDS to Children Born of HIV Infected Mothers. AIDS Patient Care and STDs, 13(1), 4145.

Li, L., Wu, S., Wu, Z., Sun, S., Cui, H., \& Jia, M. (2006). Understanding family support for people living with HIV/AIDS in Yunnan, China. AIDS and Behavior, 10(5), 509-517. doi:10.1007/s10461-006-9071-0

Marín, G. (1989). AIDS prevention among Hispanics: Needs, risk behaviors, and cultural values. Public Health Reports, 104(5), 411-415.

Mathambo, V., \& Gibbs, A. (2009). Extended family childcare arrangements in context of AIDS: Collapse or adaptation? AIDS Care, 21(S1), 22-27.

Michaud, P., Suris, J., Thomas, R., Gnehm, H., Cheseaux, J., \& MoCHIV. (2010). Coping with an HIV infection. Swiss Med Wkly, 140(17-18), 247-253.

Mitchell, C., \& Linsk, N. L. (2004). A multidimensional conceptual framework for understanding HIV/AIDS as a chronic long-term illness. Social Work, 49(3), 469477.

Patton, M. Q. (1990). Qualitative evaluation and research methods. Thousand Oaks, CA: Sage Publications, Inc.

Richter, L. (2010). An introduction to family-centered services for children affected by HIV and AIDS. Journal of the Interational AIDS Society, 13(suppl 2)(S1), 1-6. Retrieved from http://www.biomedcentral.com/1758-2652/content/13/S2/S1/

Schuster, M. A., Kanouse, D. E., Morton, S. C., Bozzette, S. A., Miu, A., Scott, G. B., \& Shapiro, M. F. (2000). HIV-infected parents and their children in the United States. American Journal of Public Health, 90(7), 1074-1081. 
Shang, X. (2009). Supporting HIV/AIDS affected families and children: The case of four Chinese counties . International Journal of Social Welfare, 18(2), 202-212.

Smith, J., Flowers, P., \& Larkin, M. (2009). Interpretative Phenomenological Analysis: Theory, Method and Research. Thousand Oaks, California: SAGE, Inc.

(UNAIDS) Joint United Nations Programme on HIV/AIDS. (2011). AIDS at 30: Nations at the crossroads. (No. 9789291738953). Geneva, Switzerland: UNAIDS.

Valenzuela, J., Buchanan, C., Radcliffe, J., Ambrose, C., Hawkins, L., Tanney, M., \& Rudy, B. (2011). Transition to adult services among behaviorally infected. Journal of Pediatric Psychology, 36(2), 134-140 . doi:10.1093/jpepsy/jsp051

Varas-Díaz, N., Serrano-García, I., \& Toro-Alfonso, J. (2004). Estigma y diferencia social: VIH/SIDA en Puerto Rico. Ediciones Huracanes.

Varas-Díaz, N., Serrano-García, I., \& Toro-Alfonso, J. (2005, February). AIDS-related stigma and social interaction: Puerto Ricans living with HIV/AIDS. Qualitative Health Research, 15(2), 169-187. doi:10.1177/1049732304272059

Vijayan, T., Benin, A. L., Wagner, K., Romano, S., \& Andiman, W. A. (2009). We never thought this would happen: Transitioning care of adolescents with perinatally acquired HIV infection from pediatrics to internal medicine. AIDS Care, 21(10), 1222-1229. doi:10.1080/09540120902730054

Wiener, L., Mellins, A., Marhefka, S., \& Battles, H. (2007). Disclosure of an HIV diagnosis to children: History, current research, and future steps. Journal of Developmental \& Behavioral Pediatrics, 28(2), 155-166. 


\section{Appendix A}

\section{Interview Guide}

\section{$\underline{\text { Personal Life }}$}

- How would you describe yourself?

o Happy, nervous, positive, negative, etc.

- What do you like to do in your leisure time?

- Do you have any goals you want to achieve in the future?

- What does “disease” mean to you?

- What does "HIV" mean to you?

- When did you find out about your diagnosis?

o How?

o Who told you?

o What did it mean to you?

- How would you describe your life before and after your diagnosis?

- How do you cope with your diagnosis?

- Have you considered becoming a parent?

- If she/he is, what has the experience been like?

- If she/he isn't what are your thoughts about it?

\section{$\underline{\text { Social Aspects }}$}

- What does "family" mean to you?

- Who have been the most meaningful people for you?

- Tell me more about your parents, who are or were they?

- How do you feel about your parents or what do you think about them?

- In your opinion, how does your family deal with HIV?

- Tell me about your experience at school, university or work environment?

- What do you consider most important before disclosing your diagnosis to others?

- Do your siblings or other family members know about your diagnosis?

- What do you consider are the pros and cons of disclosing your diagnosis?

- What does "friendship" mean to you? 
- What are your thoughts about intimacy in a relationship?

- Do you disclose your HIV status with intimate partners?

- Does your diagnosis have implications in your personal relationships? Positive? Negative? Would you give me an example?

Medical Aspects

- Tell me about your experiences with your health care providers (physicians, nurses, pharmacists, emergency room personnel, etc.)

- How long have you been taking medications?

- What does “medication” mean to you?

- What factors facilitate (or not) taking your medications?

- What additional services would you like to receive?

- How do you feel about your transition to adult care?

o How do you envision your adult care?

- What do you think about PREP for prevention? 


\section{Appendix B}

\section{Spanish quotes for the manuscript:}

\section{“That's True Love:” Lived Experiences of Puerto Rican Perinatally HIV-Infected Youth within Their Families Context}

- Mi vida. Mi familia es mi todo. Familia es...(silencio) todo para mí, como esa partecita de uno (Emma, 20 años).

- Bueno, la familia para mí es un grupo de apoyo tu sabes que es esencial para todo ser humano tener ese calor, ese afecto, porque son las personas que simbolizan seguridad para el ser humano, simbolizan unidad, tu sabes y es algo, de verdad bien bonito cuando la familia está unida, se mantiene siempre en contacto, se apoyan unos a otros, y eso es realmente lo que se debería hacer en un núcleo familiar (Mauricio, 19 años).

- Bueno, por parte de madre, puff súper bien. Mi familia de parte de padre ahí ya yo he visto la ignorancia y yo tengo unas primas que no son muy...yo soy bien 'clingy' y bien tocona, y bien abrazona y ellas tu sabes, pero por ser eso, porque con mis hermanas son locas. Pero desde chiquita yo siempre he sido la excluida, por lo menos con ellas y su mamá. Su mamá siempre fue bien...tu sabes. Pero nada 'no se abracen mucho', no...ignorancia pero yo la he visto de parte de padre completamente son mucho más (gesto como de rechazo, aauuhh) que el love. Es cómico porque su hermano como quien dice era, él lo tenía también, ujum- pero pues (Marina, 23 años). 
- La hermana de mi abuela, que le decimos titi, ella cuando venía a visitarnos ella no quería coger de nuestra comida, no quería beber del mismo vaso (Luz, 23 años).

- [Ella] no lo tiene se ponen a divulgarlo porque nunca nos hemos llevado bien [LE HAS HABLADO O DICHO COMO TE SIENTES?] La que tomaba ese papel de hablarle era mami, pero a mi mai como que muchas veces [su hermana] le faltó el respeto peor (Kathy, 21 años).

- Mi experiencia (risas de ella) son mi segunda familia, yo llevo aquí toda mi vida y de verdad...[ ] son mi segunda familia y son gente que ha tomado, a mi familia también a mis abuelos tu sabes, y mi experiencia al corazón tu sabes, y me han tratado bien (risas de ella) (Marina, 23 años).

- Pues, súper bien, ellos son como parte de mi familia ya. Todos me vieron nacer, me han visto como me he desarrollado. [ ] La calidad, la calidad humano que son ellos. Ellos son muy especiales para mí. Muy especiales para mi....eso es lo más que voy a extrañar, porque yo sé que la medicina está y cualquier médico me puede recetar, pero no es cuestión médico, es que se preocupan por ti, te pregunten... eso vale más que todo (Arturo, 22 años).

- [ ] realmente, nunca me han vuelto a tratarme como me tratan en [la clínica de VIH/SIDA de la Universidad de Puerto Rico]. Ellos vienen siendo mi familia, ellos vienen siendo mi mama, mi papa, todo el mundo está ahí, tu sabes eso es, mis regaños los cogía, todo, todo, todo, era una cosa como bien familiar, bien familiar y cuando voy a otra institución a tratarme, no es lo mismo (Esteban, 26 años). 
- Bueno porque aquí los doctores, en [la clínica de VIH/SIDA de la UPR] me han tenido unos muy buenos psicólogos, muy buenos doctores que me han ayudado a tu sabes a aceptar mi condición y siempre, desde pequeño, aunque no me decían cual era la condición pero si me enseñaron a valorarme a no sentirme menos que nadie, que me ayudaron mucho a ser una persona segura. Me enseñaron a ser una persona segura y entonces todas esas palabras de motivación de parte de los psicólogos, de los doctores, pues de mi familia, también de grupos de la iglesia. Fíjate no tengo quejas de ninguno, porque aparte de ser profesionales de la salud, de ser enfermeros o médicos, pues han sido también una mano amiga, han sido una mano amiga, me han apoyado y han sido más bien para mí como parte de una familia. Son como una familia para mí (Mauricio, 19 años).

- Mi mamá, que estaba aquí (risa de ella) pues ella siempre...ella es mi vida, yo a ella la amo, ella siempre ha estado ahí conmigo, siempre. Pues eso mismo [me siento] afortunada, afortunada de tenerla conmigo. Tenerla sanita. [TU CREES QUE HA SIDO MAS LLEVADAERO EL QUE TENGAS UNA COMPAÑERA] Sí, siempre me está hablando de las cosas que hay nuevas. Ella es la que me dice (nombre de la participante) las pastillas, las pastillas porque cada vez que ella se las bebe me las saca a mí. Este y orgullosa de ella, porque ella sí ha luchado mucho, una luchadora (Emma, 20 años).

- Mi madre. Es mi ejemplo primordial, una mujer luchadora, siempre, bueno al sol de hoy tengo 23 ella es GI más con los medicamentos, las citas, mira tú ves, venimos a las citas juntas. Ella siempre ha venido a mis citas de [la clínica de VIH/SIDA de la UPR] y de verdad que ella es mi mayor ejemplo. [Me siento] 
Afortunada. Imagínate y a pesar de que pues compartimos, como te digo, la misma condición siempre estamos ahí de la mano la una a la otra. De verdad, dándole mucha gracias a Dios, porque a pesar de la condición estamos bien. $Y$ pues, rogar para que siga así y tenerla por bastante tiempo (Carla, 23 años).

- Ahí me explicaron que era que papi usaba drogas y contagió a mami y que mami me contagió a mí, y así fue todo. [Y TU PAPA?] Bueno es que de mi papá yo, no de' so mucho, eh, no te voy a negar que siento mucho rencor hacia él aunque está muerto... pero no lo puedo perdonar (Fernanda, 29 años).

- En estos momentos a quien yo odio es a mi papá. Porque el sabiendo lo que tenía, y la situación en la que él estaba no le importó y no cuidó a mi mama. [O SEA EL LO SABIA] Él lo sabía, de hecho, antes de estar con mi mamá, por causa de él ya habían muerto 3 o 4 mujeres de la misma área de donde vivía mi mamá (Isabel, 22 años).

- Cuando mami me explicó por qué fue que lo tuve, lo tengo, pues me molesté con mi padre y desde entonces nunca he querido, él está muerto, él se murió a los veinti algo. Que bueno que está muerto porque si no lo mato (Luz, 23 años).

- Pues yo creo que hasta el sol de hoy, aunque lo nieguen es un rencor hacia mi padre, obviamente porque en un sentido si fue culpa de él. Mi hermana la que nunca lo acepto, todavía hasta el sol de hoy que ella odia a mi padre, ella lo odia y se expresa de esa manera, como que ¿por qué no él en vez de mi mama?. Y yo creo que mi abuela, siempre tuve rencor hacia mi padre también [] pero hay rencor hacia él, porque por culpa de él, ella falleció. [] yo lo tuve que perdonar también. [] Pero yo personalmente si tuve que perdonarlo, en el sentido de que, 
sí es culpa de él, pero como dije, yo tengo valores, y yo digo Dios sabe lo que hace porque de toda mi familia y de todos mis hermanos, yo soy la única que creo en Dios y que tengo fe. Y eso para mí no es una coincidencia, de que yo, que soy la menor, soy la que nací con eso, creo en Dios y tengo Fe. Eso para mi, no es una coincidencia (Marina, 23 años).

- Na' uno... y no me siento mal porque no me siento mal. Es como yo digo, yo sé que si hubiese sido por ella no lo hubiese tenido porque es mi Mai y yo sé que ella me quería y mi Pai también, ellos me aman, tu sabes que no me siento así... yo no los pongo como culpables. Culpables la circunstancias porque cada cual tiene su y no todo el mundo es perfecto y ellos tuvieron sus errores, pues, no puedo juzgarlos por eso, no me voy a poner a decir que ellos son malos, son esto, porque por lo menos me dieron la vida y hasta el día de hoy estoy bastante grande y gordo [carcajadas de ambos] de verdad que yo por lo menos no me siento mal así (Alonso, 20 años).

- Mi mamá murió, esa es mi abuela, mi mamá falleció el mismo día de mi primer año. Mi mamá falleció, mi papa me abandonó y me quien me crió fue mi abuela. [ ] Es bien, bien doloroso, porque pues mi mamá a penas lo que tenía era 26 años cuando murió, una nena. Y el no poder, como te digo, no poder tenerla al lado, en los momentos que pues me enteré de la condición, y que pues me ayudara, escucharle la voz, saber cómo hablaba, el poderla sentir al lado mío, hubiéramos pasado lo mismo, nos hubiéramos podido entender tanto y el no poder haber vivido esas experiencias pues... (Isabel, 22 años). 
- Si, bueno verdad porque, cuando yo perdí a mi Mai', por también parte de lo de la condición, que cuando yo tenía 5 años y ella tenía 21. [ ] Eso a mí no me afectaba en ese momento, no era por na' de la condición, en sí. En sí era como yo perdí a mi Maí, hubo un tiempo que me, como que me traumé, me traumaticé, pero me llevaron a psiquiatra, psicólogos y eso y me ayudó y na' después seguí adelante poco a poco (Alonso, 20 años).

- El choque más grande fue que mis papás murieron y yo tenía solamente 4 años. [AMBOS MURIEON CUANDO TENÍAS 4?] Sí, uno en junio y otro en julio. [Solo] un mes de diferencia (Arturo, 22 años).

- Que eso era amor de verdad, porque no todo el mundo hace eso, no todo el mundo hace eso. Y más yo, yo era chiquita, tenía la condición y después me dio, no sé qué me dio pero estaba a punto de morirme. Yo era, yo nací, pesando 4 libras, yo era una cosa bien chiquita, media 13" o algo así, yo era bien chiquitita, bien chiquitita. Y ella al verme, pues se enamoró de mí y pues me adoptó y que sé yo pero después de eso se complicó la cosa yo me enfermé, estuve par de tiempo en el hospital (Victoria, 18 años).

- [hablando de los padres adoptivos] Sí, ellos no conocen a mis verdaderos padres ni nada. Es algo como que ellos me dieron la vida y ellos [los adoptivos] estuvieron ahí y yo veía que tu sabes, yo no me puedo mojar, se supone que yo no me moje porque pues, eh, rápido me da una tosecita [ ] Y ellos siempre estaban ahí para mí, siempre me traían al hospital constantemente y para eso no teníamos carro y la, el trayecto era bien largo porque al coger guagua, a veces nos 
enchumbábamos, era una cosa, de verdad agradezco que me hayan adoptado, porque han sido unos padres responsable (Esteban, 26 años).

- Pues cuando yo estaba tan enfermita, tu sabes yo a los dos meses de nacidas estaba...mis abuelos estaban, porque mis abuelos siempre fueron muy cercanos con mi mamá, estaban en desespero y cuando me llevaron al hospital [] a mi abuela le dijeron mi [ ] Se lo dijeron a mi abuela y mi abuela, bueno decía [] que ella no pudo, ella cayó en depresión, también por mi mamá. Al mi mamá fallecer, pero fue algo bien impactante para ellos... [ ] Pero fue impactante para ellos, también al igual que en la ignorancia porque no sabían que hacer, no sabían que el 89 una bebe aquí de dos meses muriéndose, como quien dice, tu sabes no sabían que hacer y los doctores le decían "mira ella no va a durar mucho." [ ] Fue algo bien fuerte para ellos aceptar y reconocer y tratar de lived trhough it (Marina, 23 años).

- Porque yo me fui de mi casa un fin de semana y cuando me fui, pues ellos, cuando volví a aparecer, pues mi tía me dijo que, qué era lo que yo quería, que yo no podía hacerle eso de irme de su casa, que estaba asustá, porque mami ya había muerto y yo, cuando mami murió me puse rebelde (Fernanda, 29 años).

- Yo pasé por la drogadicción. Esa fue otra experiencia, que después que yo me enteré de mi condición. Me empecé a juntar mucho con una prima y empecé a conocer lo que era la marihuana, el cigarrillo, el perico, el crack. [TODO ESO LO TRATASTE] Todo eso lo probé, porque no puedo decir que me metí porque si no no estuviera aquí. Pero si lo probé, llegué a utilizarlo aunque sea una vez. Y te digo, yo me volví bien loquita, pero no me arrepiento porque creo que eso fue 
un proceso que tuve que vivir por lo que pasó. Ahora lo que importa es hacer el cambio y la diferencia y demostrarle a mis hijos que eso está mal (Isabel, 22 años).

- Va a ser un poco difícil. Porque no va a ser como un proceso normal, porque voy a tener que estar más precavida que cualquier otra madre y pues... (Emilia, 21 años).

- No me siento preparada para un muchacho ahora y me basta con mis sobrinos. Pero me gustaría pero ahora mismo no (Kathy, 21 años).

- [hablando de cuando le gustaría ser padre] cuando tenga un trabajo decente, me establezca y tenga una casa (Rodrigo, 21 años).

- [Hablando de la experiencia de ser madre]Brutal. Es buena, es difícil pero es bueno (Luz, 23 años).

- [Hablando de la experiencia de ser padre] Muy satisfactoria y enriquecedora. Muy buena de verdad (Arturo, 22 años).

- Aunque no lo tengan van a quererlos discriminar, porque van a pensar que lo tienen, porque hay mucha gente ignorante en esta vida. Y eso detalle, de que si los pegan a relajar, que ellos lleguen a casa y me peguen a juzgar, que por culpa tuya me están tratando así, que...y tener que vivir es experiencia me da miedo. Me da miedo... (Isabel, 22 años). 


\section{CONCLUDING REMARKS AND RECOMMENDATIONS TO INFORM HIV INTERVENTIONS}

By listening to the voices of pHIV-I youth, this study provided the opportunity to reconstruct and express themselves about their life experiences with HIV, while also informing the scientific world about their life trajectory and psychosocial aspects of their lives. In-depth interviews, based on the interpretative phenomenological analysis (IPA) framework, allowed each study participant to speak freely about his/her daily life experiences as a youth, as a student, as a family member, as an employee, as a parent and as an individual living with HIV due to perinatal transmission. The main objective of this study was to examine how perinatally-infected youth experience and describe the impact of HIV in their lives, however, the interview also explored broader aspects of their lives. It was expected that significant issues affecting each individual would arise in the course of the interview. Following the tenets of the IPA approach, capturing the voices of pHIV-I in Puerto Rico enabled the researchers to draw a holistic perspective of their everyday life experiences as young adults living with HIV. And as suggested by IPA, in the process of narrating their lives' experiences they were concurrently interpreting what a particular situation meant to them and how they make sense of it now. The aim was to learn from their interpretations "in the light of the present" (Smith, Flowers, \& Larkin, 2009, p. 27).

The sample size $(\mathrm{n}=20)$ was considered large for a phenomenological study (Smith, Flowers, \& Larkin, 2009); however, each of the interview transcripts was evaluated in its own terms, allowing new themes to emerge. This process helped us to guarantee the idiographic component of IPA (Smith, Flowers, \& Larkin, 2009). The 
information gathered in this study helps us to better understand the lives of pHIV-I youth in Puerto Rico, specifically those who shared the same contextual experiences of receiving care at the UPR Pediatric HIV/AIDS Research Program. Guided by the theoretical framework and after coding each of the interviews, three broad topics emerged: (1) perception and response to treatment and illness, particularly their lived experiences with ART; (2) disclosure experiences; and (3) family matters.

Participants’ testimonies regarding their experience and challenges to be adherent to ART highlighted the importance of approaching the patient as a whole individual, not just as an HIV patient. As repeatedly noted by study participants, most challenged their therapy at some point in their lives. This was usually the case where this approach was intended to force their parents or caregivers to reveal the truth about their diagnosis. At this major point in their lives, the problems with ART adherence were attributed to their busy schedule or forgetfulness. The difficulties of ART adherence among this population can be better understood if professionals modify their perspective. They indicated their preference to be treated as individuals with a health condition rather than an HIV patient. Participants in general indicated three successful strategies to support their adherence to ART, these were: the use of pill boxes, alarm on their cellular phones and the assistance of friends and family.

When commenting on their disclosure experiences, participants were in agreement on the importance of assigning to the individual the capacity for selfmanagement of her/his health condition. Most study participants said they felt “betrayed” by their caregivers because they had concealed their diagnosis. This paternalistic approach, adopted in order to spare study participants from suffering, 
however, in their opinion, caused them more anxiety and stress than knowing the truth about their health situation. Their comments strengthen the position that in order to manage their diagnosis effectively, it is best to provide these patients with honest information and useful tools, appropriate to their developmental stages, in order for them to manage their diagnosis effectively. In terms of designing interventions for pHIVyouth, this research supports the importance of providing management strategies not only for their health situation but also for its social implications. The majority of study participants acknowledged that disclosing their HIV status to their partners was one of the most difficult things they have done. Service strategies should, therefore, see patients as holistic human beings, exactly how they see themselves, in order to better prepare them to deal with their social and personal interactions. In addition, medical or health services should include the patient's families and relatives in designing the appropriate therapeutic strategy focusing in a holistic approach.

Their life experiences regarding family demonstrated that family and close friends were an essential component in dealing and coping with their HIV-diagnosis. "Family" represented not only people who supported and loved them, but their "life" and their "world". While some study participants reported encountering discrimination and stigma, within their own families, they recognized that there were more positive than negative experiences. Within this family context, strong parental figures helped and guided them throughout their childhood and adolescence. Participants who suffered the loss of their parents found other parental figures such as adoptive parents or other family members (e.g., grandparents, an aunt, a cousin) who cared of them. Even when loving and supporting parental figures played strong roles in their lives, participants who lost their 
parents acknowledged that the absence of a parent, or both, was the most difficult experience they had to confront in their lives. The medical services and care they have received in the UPR Pediatric HIV/AIDS Research Program have led them to consider the personnel as part of their family. What study participants considered essential and unique in their health care, was the real interest that these caregivers took in their lives, not only regarding HIV, but all aspects of their lives. When sharing the difficult situations they experienced in life, they recognized that their health care providers had been mostly by their side. They, therefore, consider them as pillars in their lives. As most observed, medical care is easy to get, love, care and real concern for their well-being are not that easy to find.

Perinatally HIV-infected youth will require health services for the rest of their lives. The data presented here strongly suggest that the transition into adult health care marks an important life transition in their individual health trajectories. Therefore, this transition needs to consider the individual situation of those involved, with special consideration to their needs and what is known to be effective. From the narratives of participants who experienced or are undergoing this transition, we learn that they deem necessary to receive special information and education regarding the management of their condition and to navigate the adult health system they now will need to enter. As part of this process, some participants were skilled at navigating the new situation while others were not. This points to the importance of preparing those entering the transition to adult treatment on becoming advocates for their needs.

As evidenced in participants' narratives, HIV is a health condition that impacts not only the patients but also their families and relatives. Repeatedly data presented here 
point to the constant involvement of family members in all areas of participants' lives; thus, given this narrative, it is important to stress the need for health services to consider including patients' family members in all aspects of their care. From participants' narratives, we learn that it is also necessary to go beyond what is considered "medical" and include a broader perspective of health care. In light of these findings, health care services need to target patient wellbeing, going beyond simple metrics such as CD4 counts and viral load. Findings presented here indicate that care needs to include the psychological and psychosocial aspect of the individual; and adult health services need to provide the patient the necessary tools to succeed not only in the medical aspects of the condition but also emotionally and socially.

Findings underscore the need to include mental health services within the content of adult health care for this population. As their narratives reveal, this is a population that has experienced very difficult life situations, repercussions of these are still felt by some of our participants who continue to suffer from many earlier events in their lives. Based on their comments, we suggest that psychological services will be beneficial to these patients in overcoming or managing earlier emotions that still linger, such as the feelings of anger that some participants still demonstrate toward their fathers. In addition, narratives from these participants suggest that health care services will do well in including reproductive counselling and decision-making services. This is a population that is in its reproductive years and most expressed a desire to have children at some point in their lives. Reproductive health should therefore be an essential component of adult health care. In addition, it will be important to provide HIV health education and 
prevention to the patients' partners, since as participants noted, their partners also face issues of their own.

Rather than a conclusion constructed by the researcher only, earlier in the investigation and following the tenets of IPA, it was decided that participants in the study should also have a voice. Hence, at the end of the interview, participants were encouraged to share a general message that they thought important to convey to the larger society. They took advantage of the opportunity and readily shared their thoughts with the researcher/interviewer. Almost in unison, they indicated that society needs to know the following: (1) having HIV is not the end of the world; (2) HIV is just like any other disease, those who suffer from the disease need to treat it and they will be fine; (3) HIV does not define them: they are much more than their health condition; (4) we [society] need to get educated about HIV in order to battle ignorance and stigma; (5) we [society] should not judge, them or anyone; (6) they are like any other youth and should be treated as such; and, (7) they are one of a kind, simply the best! 


\section{Reference}

Smith, J., Flowers, P., \& Larkin, M. (2009). Interpretative Phenomenological Analysis: Theory, Method and Research. Thousand Oaks, California: SAGE, Inc. 


\section{STUDY LIMITATIONS}

\section{Methodological Limitations}

Several study limitations need to be discussed. First, due to sample size and the nature of the study, generalization of study findings cannot be made. Participants' life experiences are individual and context-dependent. Therefore, the life experiences of pHIV-I youth in the metropolitan area of Puerto Rico may not be the same as that of a youth in the rural area or in another Caribbean island.

Second, two potential participants were invited to take part in the study but refused to participate. One of the potential participants had a busy work and study schedule and could not find an appropriate time for the interview; and the other one did explain or justify the reason for refusal.

\section{Procedural Limitations}

One procedural limitation included age for consent to participate in the study. In Puerto Rico, participants under the age of 21 are considered minors. Regulatory agencies require a parent or guardian to provide informed consent in writing, in addition to the signature of the minor (assent form is used with minors under the age of 18). Obtaining the signature of the parent or guardian of potential participants under 21 was not always easy. Most already are independent and live on their own; asking their parents or guardian to come to the clinic just to sign a form was not feasible at times. 


\section{FUTURE PATHS}

The manuscripts integrated on this dissertation reflect three prominent perspectives of the lives of pHIV-I youth in Puerto Rico. The topics of the manuscripts were about participants' lived experiences with ART, HIV disclosure and family matters. There are others standpoints in which the data will be examined in future papers. Some these topics are: gender differences and its influence on how participants deal with their HIV status and their intimate relationship; and culture and religious belief and how these aspects influence participant's daily behaviors and attitudes after learning their HIV diagnosis. Furthermore, their perception about Pre-exposure prophylaxis as an HIV prevention strategy will be examined. 
APPENDICES 
Appendix 1 - Letter of IRB Approval 


\title{
MEMORANDUM
}

\author{
To: $\quad$ Dr. Irma Febo \\ CC: $\quad$ Dr. Elena Bastida \\ From: $\quad$ Jada Dixon, MJ, MPH, IRB Coordinator $9 \mathcal{P}$ \\ Date: $\quad$ October 22, 2012 \\ Proposal Title: "Life Experiences of The Youth Who Were Bom With HIV in Puerto Rico: The \\ Voices of Young Survivors"
}

IRB Approval \# $\quad$ 092612-00

The Social and Behavioral Institutional Review Board of Florida International University has approved your study for the use of human subjects via the Expedited Review process. Your study was found to be in compliance with this institution's Federal Wide Assurance (00000060).

Your $\mathbb{R B}$ approval date is September 26, 2012 and it will expire on September 26, 2013. As a requirement of $I R B$ approval you are required to:

1) Provide immediate written notification to the IRB of

- Any additions to, or changes in the procedures involving human subjects.

- Every serious or unusual or unanticipated adverse event as well as problems with the rights or welfare of the human subjects. Confirmation of receipt of serious $\mathrm{AE}$ reports must be made with the IRB office.

2) Utilize copies of the date stamped consent document(s) for the recruitment of subjects and receive annual renewal of consent documents.

3) Receive annual review and re-approval prior to your expiration date. Projects should be submitted for renewal at least 30 days in advance of the expiration date.

4) Close out your project with the IRB office when the study is finished or discontinued.

Special Conditions: N/A

Please note that your IRB approval number is indicated above. For further information, you may visit the IRB website at $\underline{h t t p}: / /$ research fiu.edu/compliance/compliance.html. 


\section{MEMORANDUM}

To:

Dr. Elena Bastida

CC: File

From:

Donna J. Simonovitch, Coordinator, Research Integrity

Date:

April 14, 2014

Protocol Title: Life experiences of the youth who were born with HIV in Puerto Rico:

The voices of young survivors

The Florida Intemational University Office of Research Integity has reviewed your research study for the use of human subjects via the Exempt Review process.

IRB Protocol Exemption \#: IRB-14-0059 IRB Exemption Date: 04/14/14 TOPAZ Reference \#: $\quad 102354$

As a requirement of $\mathbb{R} B$ Exemption you are required to:

1) Submit an Event Form and provide immediate notification of:

- Any additions or changes in the procedures involving human subjects.

- Every serious or unusual or unanticipated adverse event as well as problems with the rights or welfare of the human subjects.

2) Submit a Project Completion Report Form when the study is finished or discontinued.

$$
\begin{aligned}
& \text { Special } \\
& \text { Conditions: }
\end{aligned}
$$

For further information, you may visit the IRB website at $h$ ttp:///research fiuedu/irb. 


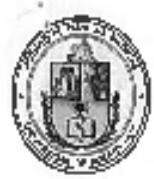

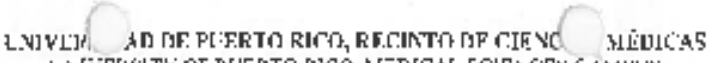

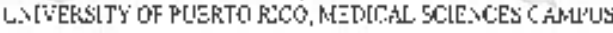

OFICINA IJFI. RF.C.TOR

OFFICE OH T'AE C:LANCELLUH

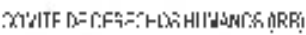

P.8ITUTIEWHL P.EVEW ECHAD

Data: Jute 20́, 2012

Protocol Number: 0400412

Principal lnvastigator: Inua Fcbo

Department / Division: 5idhos of Misdisiliz - Depeltucs of Medicinc

Sponвar: $\mathrm{N} l \mathrm{H}$

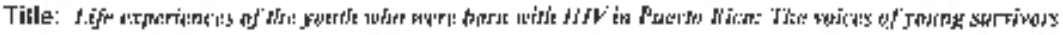

Thank you for your response to rectuests from a prior raview of your apprichtion. This type of resqoinge qua ifics tor cxpedite reviow sunder foderal rogulations. This ls to con'irm that your apslication is now fully eppraved. A pragress 'epcrt (continujing revie'w) is due in one year and' or at the end of the study

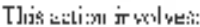

\ New proprestipeojo:

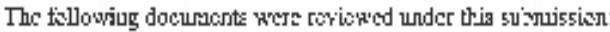

\ Informed Cousent Document

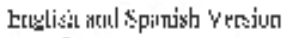

$\triangle$ Suricy tristumi:cat

オ Humar Su'jjen Certificd

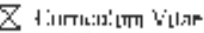

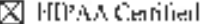 \\ Authorizatiou Letber

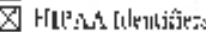

П Otbers:

In compliance with fadaral regulatio acdlfional Informatlon please contacl bluman Research Subjects Puoteclior Ofluce al 787-752-2525

Exts. 2510-2515; e-mail opphi.romanux.edd.

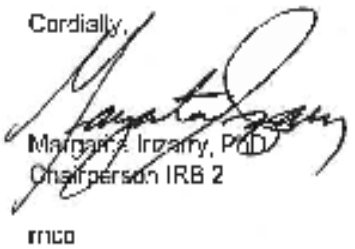

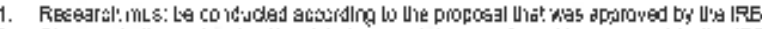

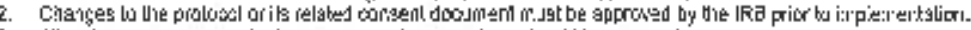

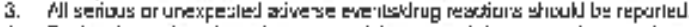

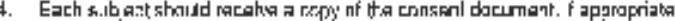

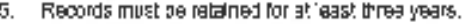

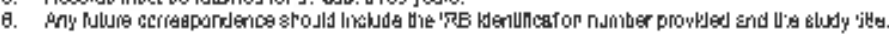

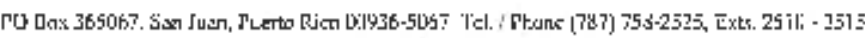

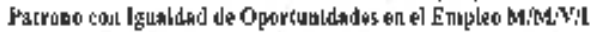

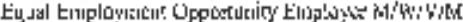




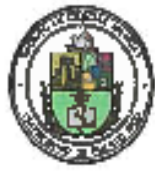

UNWERSIDAD DE PUERTO RLCO, FEGINTO DE CIENCIAS MÉDICAS

UNN|VCRㅁTYY OF PUCRTD RICD, MEDICAL SCIICNCLS CAMPUS

OHENAA OEL FECTOR

DFFICE OF THE CHWIYCELIDR

COMTE DE DERECHOS HUMANOS XIRB'

INSTITUTONAL REVIEN BOARD

Date: April 24. 2014

Protocol Number: 0400412

Frincipal Investlgator: Dr. Irma L. Fẹbo

Departmemt I Divișion: Schopol of Medtictne - Departiment of Pediatrics

Sponsor: $\mathrm{NIH}$

Title: Life experiences of the youth who were bem with HN in Puerto Fico: The volces of young survivors

This is to certify that this continuing revieur $\$ 2$ was evaluated on April 24, 2014 and meets full board IRB reyiew caltegdry. The rese日rch proposal was approved. The approval period for thls continulng rewlew is Aprll 24, 2014 to Aprlt 24, 2015.

This action Involwes:

区 Data Analysis Only

This pojedet includdes children or abolemcents IR日 determined the riak' benefit category as:

区 45 CFR 646.405 Research inveluing greater than minimal risk but presentling the prospect of direcx benefit to the individual subjects.

For additional information please contact Human Research Subjects Protectlon Ofilce at 787-758-2525 exts. 2510 to 2515; entrail opphi.rm(a)upr.edur.

Cordially,

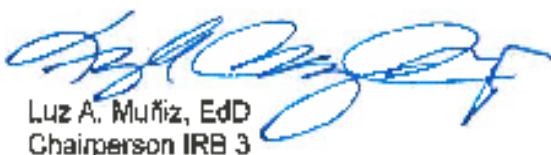

$\operatorname{bog}$

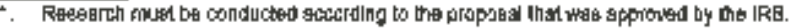

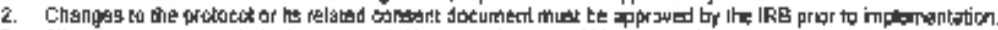

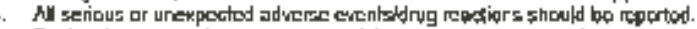

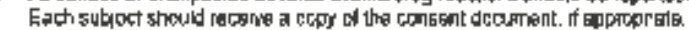

F. Ficonde muat be retarend for at lagat three years.

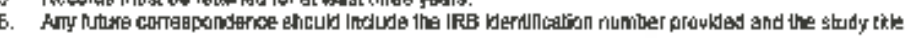

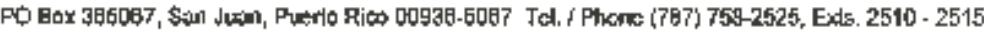

Pationo con |gualdad do Oportunidader on el Empleo MAMVl|

Equal Emplayment Opportunity Empotyer twWrism 


\section{Appendix 2 - Spanish Interview Guide}


ID del participante:

Universidad de Puerto Rico

Reciento de Ciencias Médicas

$\&$

Universidad Internacional de la Florida

Miami, Florida

Georgina Silva-Suárez, $\mathrm{PhD}(\mathrm{c}), \mathrm{MPH}$

Estudiante doctoral del Programa de

Promoción de la Salud

\& Prevención de Enfermedad

Experiencias de vida de ióvenes que nacieron con VIH in Puerto Rico:

Las voces de los ióvenes sobrevivientes

ID del participante:

Fecha:

Lugar de la entrevista:

Hora de comienzo:

$\mathrm{am} / \mathrm{pm}$

Hora que finaliza: $\mathrm{am} / \mathrm{pm}$

Introducción:

Le agradecemos que haya decidido participar en este estudio de investigación. El estudio consiste de una entrevista dividida en las siguientes secciones: información demográfica, vida personal, aspectos sociales y aspectos médicos. Cada sección está compuesta de varias preguntas. El objetivo de la entrevista es obtener información sobre sus experiencias de vida como joven perinatal viviendo con VIH.

Para garantizar la fidelidad de la transcripción y del análisis, la entrevista debe ser grabada. Recuerda que la información que discutamos durante la entrevista será confidencial y solamente las investigadoras tendrán acceso a ella. El producto final de las entrevistas no contendrá ninguna información que pueda identificarte ni a ti ni a ningún otro participante.

¿Estás de acuerdo en que grabemos y comencemos la entrevista?

¡Gracias! 
I. Información demográfica:
a. Género:
b. Edad:
c. Año de nacimiento:
d. Con quién vives:
e. Estado civil: Soltero
Casado legalmente Conviviendo
Divorciado
Separado
Nivel académico más alto completado:
Escuela elemental
__ Escuela intermedia
Escuela superior
Bachillerato
Estudios Graduado
Ninguno
g. Estudias actualmente: Sí
No
h. Trabajas actualmente: Si
No
i. A qué te dedicas: 
ID del participante:

II. Vida Personal

1. ¿Cómo te describirías como persona?

a. alegre, nervioso, positivo, negativo, etc.

2. ¿Qué te gusta hacer en tu tiempo libre?

3. Tienes alguna meta que te gustaría cumplir en el futuro.

4. ¿Qué significa para ti enfermedad?

5. ¿Qué significa VIH para ti?

6. ¿Cuándo te enteraste de tu diagnóstico?

a. ¿Cómo?

b. ¿Quién te lo dijo?

c. ¿Qué pensaste, qué significó para ti?

7. ¿Cómo describirías tu vida antes y después de diagnóstico?

8. ¿Cómo manejas tu diagnóstico?

9. ¿Has considerado convertirte en padre o madre?

a. Si ella/el es padre o madre, ¿Cómo ha sido esa experiencia para ti?

b. Si ella/el no es padre o madre, ¿Qué piensas de convertirte en padre o madre?

III. Aspectos Sociales

10. Si digo "familia", ¿qué significa esto para ti?

11. ¿Quiénes han sido las personas más significativas para ti?

12. Cuéntame más sobre tus padres, ¿Quiénes son o quiénes eran?

13. ¿Cómo te sientes o que piensas de tus padres?

14. ¿Cómo piensas que tu familia maneja el VIH?

15. ¿Cómo ha sido tu experiencia en la escuela, universidad o ambiente de trabajo?

16. ¿Qué cosas consideras antes de revelar tu diagnóstico a otros?

17. ¿Tus hermanos o familiares saben tu diagnóstico?

18. ¿Cuáles son los pros y contras de revelar Tú diagnóstico?

19. ¿Qué significa la amistad para ti?

20. ¿Qué piensas de las relaciones íntimas de pareja?

21. ¿Revelas Tú diagnóstico a parejas íntimas?

22. ¿Crees que el diagnóstico de VIH ha impactado de forma positiva o negativa tus relaciones con otras personas? ¿Me das un ejemplo?

IV. Aspectos Médicos v de Salud

23. Cuál ha sido tu experiencia con las personas que cuidan de tu salud (ex. En la clínica, enfermeras, farmacia, sala de emergencia)....

24. ¿Cuánto tiempo llevas tomando medicamentos?

25. ¿Qué significan los medicamentos para ti?

Página 3 de 4 
ID del participante:

26. ¿Qué factores influyen o contribuyen a que tomes los medicamentos?

27. Más allá de lo que recibes actualmente, ¿Qué otras cosas o servicios te gustaría recibir como parte de Tú cuidado de salud?

28. ¿Cómo te sientes respecto a la transición del cuidado pediátrico al cuidado adulto?

a. ¿Cómo visualizas o imaginas el cuidado de salud en una clínica de adulto?

* Si tuvieras la oportunidad de decir algo a la sociedad en relación a los jóvenes perinatales viviendo con VIH, ¿Qué nos dirías?

$\therefore$ Que cosas positivas de tu vida quieres resaltar.

Quiero agradecerte tu disponibilidad para participar en esta entrevista. Muchas gracias por compartir tus experiencias y conocimiento conmigo.

Página 4 de 4 
Appendix 3 - English Interview Guide 
University of Puerto Rico

Medical Sciences Campus

8

Florida International University

Miami, Florida

Georgina Silva-Suárez, Ph.D(c), MPH

Health Promotion \& Disease Prevention

Doctoral Student

Life experiences of the youth who were born with HIV in Puerto Rico: the voices of young survivors

Participant ID:

Interview venue:

Date:

Starting time: $\quad: \quad a \quad a m / p m$

Ending time:

Introduction:

We really appreciate your participation in this research study. This interview consists of four aspects: demographic, personal life, social, and medical. Each section will have subsequent questions. The objective of the interview is to gather information about your life experiences as a youth living with HIV due to perinatal transmission.

This interview will be recorded to assure the integrity of the transcription. Remember that the information that we share here is confidential and only the principal investigator and co-principal investigator will have access to it. The final product of these interviews will not contain any information that identifies you. Do you allow me to record and begin the interview?

Thank you! 
SOCIO-DEMOGRAPHICS

I. Demographic Information:

a. Gender:

b. Age:

c. Year of birth:

d. With whom do you live:

e. Marital Status:

Single

Married
Living together

Married
Living together

Divorced

\begin{tabular}{l} 
Divorced \\
Separated \\
\hline Widow
\end{tabular}

f. Highest academic degree completed: Elementary School

Middle School

College degree

High School

Graduate degree

None of the above

g. Are you currently a student: Yes

No

h. Are currently working:

Yes

No

i. What do you do: 
1. How would you describe yourself?

a. Happy, nervous, positive, negative, etc.

2. What do you like to do in your leisure time?

3. Do you have any goals you want to achieve in the future?

4. What does "disease" means to you?

5. What does "HIV" means to you?

6. When did you find out about your diagnosis?

a. How?

b. Who told you?

c. What did it mean to you?

7. How would you describe your life before and after your diagnosis?

8. How do you cope with your diagnosis?

9. Have you considered becoming a parent?

i. If she/he is, what has the experience been like?

ii. If she/he isn't what are your thoughts about it?

\section{Social Aspects}

10. What does "family" means to you?

11. Who have been the most meaningful people for you?

12. Tell me more about your parents, who are or were they?

13. How do you feel about your parents or what do you think about them?

14. How do you think your family deals with HIV?

15. How has your experience been at school, university or work environment?

16. What are the things that you consider before disclosing your diagnosis to others? 
17. Do your siblings or other family members know about your diagnosis?

18. What do you consider are the pros and cons of disclosing your diagnosis?

19. What does "friendship" means to you?

20. What do you think about intimacy in a relationship?

21. Do you disclose your HIV status with intimate partners?

22. Does your diagnosis have implications in your personal relationships? Positive? Negative? Would you give me an example?

\section{Medical Aspects}

23. How has your experience been with your health care providers (physicians, nurses, pharmacists, emergency room personnel, etc.)

24. How long have you been taking medications?

25. What does "medication" means to you?

26. What factors facilitate (or not) taking your medications?

27. What additional services would you like to receive?

28. How do you feel about your transition to adult care?

i. How do you envision your adult care?

29. What do you think about PREP for prevention?

* If you have the opportunity to say something to the society regarding perinatal youth living with HIV, what would you say?

* Any positive things about you that you want to highlight?

* Before ending the interview, I will like to ask you if there is anything that you want to say that we didn't talk about.

I really appreciate your time and willingness to participate in this study. Thank you for sharing your knowledge and experiences with us. 
VITA

GEORGINA SILVA-SUÁREZ

EDUCATION

2014

Ph.D. (Candidate) in Public Health

Florida International University, Miami

2008

Graduate Certificate in School Health Promotion

University of Puerto Rico, Medical Sciences Campus

2006

Master in Public Health Education

University of Puerto Rico, Medical Sciences Campus

2000

B.A. in Social Work

University of Puerto Rico, Rio Piedras Campus

PUBLICATIONS AND PRESENTATIONS

Silva-Suárez, G., Rabionet, S., Febo. I, Bastida, E. \& Zorrilla, C. How come I didn't know about PrEP? Voices of perinatally HIV-infected youth in Puerto Rico. Accepted for an oral presentation at the $142^{\text {th }}$ Annual Meeting of the American Public Health Association, New Orleans, Louisiana (November, 2014).

Silva-Suarez, G., Rabionet, S.E., Febo, I., Bastida, E. \& Zorrilla, C. Perinatally HIV infected young adults welcome PrEP and envision its potential in curtailing the epidemic. Oral presentation at the London Summit, Controlling the HIV Epidemic with Antiretrovirals: Avoiding the Cost of Inaction (September, 2014).

Capriles-Quirós, J. A., McCoy, H. V., Darrow, W. W., Ríos, R. E., Rubens, M., SilvaSuarez, G., \& Hughes, S. (2014). A Needs Assessment of Health Department Employees in Puerto Rico and Florida. Health promotion practice, 15(1 suppl), 23S-32S.

Silva-Suarez, G., Rabionet, S.E., Febo, I., Bastida, E. \& Zorrilla, C. Tough pill to swallow: Voices of perinatally HIV-infected youth. Oral presentation at the $141^{\text {th }}$ Annual Meeting American Public Health Association, Boston, Massachusetts (November, 2013).

Silva-Suarez, G., Rabionet, S.E., Febo, I. \& Zorrilla, C. Creating an interview: Capturing the voices of young HIV survivors in Puerto Rico. Poster presentation at the $4^{\text {th }}$ Public Health Puerto Rican Conference, San Juan, PR (March, 2013). 
Sánchez, J., Silva-Suarez, G., Serna, C.A. \& De La Rosa, M. (2012). The Latino migrant worker HIV prevention program: Building a community partnership through a community health worker training program. Family \& Community Health, 35, (2) 139 -146. Doi: 10.1097/FCH.0b013e318246515

Silva-Suarez, G., Virginia, M. \& Rubens, M. Florida Department of Health Workforce: Profile of Hispanic Women. Poster presentation at the $140^{\text {th }}$ Annual Meeting American Public Health Association, San Francisco, California (November, 2012).

Rubens, M., Virginia, M. \& Silva-Suarez, G. Training Needs of Florida Department of Health Hispanic Employees. Poster presentation at the $140^{\text {th }}$ Annual Meeting American Public Health Association, San Francisco, California (November, 2012).

Darrow, W.W, Silva-Suárez, G. \& Sebekos, E. Ethics, principles, practices, and issues in public and sexual health: the development, implementation, and evaluation of a masters level university course. Poster presentation at the World Congress of Sexual Health, United Kingdom (June 2011).

Silva-Suárez, G. \& Sánchez, J. Empowering communities: CBPR as a strategy for HIV prevention. Poster presentation at the 12th RCMI International Symposium on Health Disparities, Nashville, Tennessee (December, 2010).

Silva-Suárez, G. \& Sánchez, J. Practices and perceptions toward condom use among a cohort of Hispanic migrant workers in South Florida. Poster presentation at the $138^{\text {th }}$ American Public Health Association, Denver, Colorado (November, 2010). 